\title{
Morally Empowering Combatants
}

\author{
Logan Blaine Sisson \\ Colorado Springs, Colorado
}

Bachelor of Science in Humanities, United States Air Force Academy, 2000

Masters of Arts in Philosophy, University of Montana, 2001

A Dissertation presented to the Graduate Faculty

of the University of Virginia in Candidacy for the Degree of

Doctor of Philosophy

Department of Philosophy

University of Virginia

May, 2016 
For my children Laila, Jack, Laken, Eva, Quinn, and Charlotte;

May you enjoy the substance of your rights and do your part to ensure the rights of others. 


\section{Acknowledgements}

I would like to thank my advisor, Tal Brewer, for his support in this project. Just war theory is not the most popular of philosophical topics, and his willingness to reach out to support my interests is greatly appreciated. He has challenged me to sharpen my views and deepen my knowledge on a subject that may become my life's work.

I would also like to thank the members of my dissertation committee. A special thanks goes to James Childress for his insight into just war theory and for helping me shape the early stages of this project.

I have also benefited from discussion of early drafts and other topics with members of a just war theory reading group formed at The University of Virginia. In particular I would like to thank Nick Frank, Laura Alexander, Jacob Marthaller and Paul Morrow. Again, just war theory is not the most popular of philosophical topics, and I was very fortunate to find others who shared my interests. I would also like to thank Anne Llewellyn for editing my work.

At a larger level, I would like to thank the Philosophy Department of the United States Air Force Academy for twice having selected me to obtain an advanced degree and the United States Air Force for footing the bill.

Finally, I would like to thank my wife, Carla, and our children, Laila, Jack, Eva, and Charlotte for supporting me during the dissertation process and in everything else I do. My life is so much better with you in it. 


\section{Table of Contents}

$\begin{array}{ll}\text { Introduction } & 5\end{array}$

1. Just War Theory 11

2. Selective Conscientious Objection and the Moral Equality of Combatants 34

3. Henry Shue's “Institutional Turn in Thinking about Human Rights” 55

4. Shue's Tripartite Framework and Just War Theory $\quad 84$

5. Responding to Objections and Further Refinements 113

$\begin{array}{lr}\text { Concluding Thoughts } & 149\end{array}$

$\begin{array}{ll}\text { Bibliography } & 151\end{array}$

The views expressed in this work are those of the author and do not necessarily reflect the official policy or position of the United States Air Force, Department of Defense or the U.S. Government. 


\section{Introduction}

The prevailing view of just war theory leaves little room for combatants to evaluate the justice of the particular wars in which they are ordered to fight. If combatants do, and determine that they cannot in good conscience participate, state policies limit recourse by threatening imprisonment, and the just war tradition regards such threats as wholly legitimate. Recently a few theorists have raised objections to these elements of the just war tradition. They have generally argued from the bottom-up, grounding their case on individual rights and focusing primarily on individual duties in support of those rights. These bottom-up arguments are often met with the top-down objection that empowering combatants will endanger state rights or make it difficult to fulfill the duty incumbent on a state to defend its citizens. While I affirm the bottom-up arguments, I hope to bring something new to this debate by arguing for the empowerment of combatants from the top-down, grounding my case on state rights and focusing on both the state and individual duties required to uphold those rights. Ultimately, I hope to show that combatants must have, and indeed must exercise, the prerogative to refuse to fight in an unjust war. Below is a summary of each chapter in my project:

\section{Chapter One: Just War Theory}

In the first chapter, I will present the key components of the prevailing view of just war theory. Just war theory attempts to answer two questions: When is it just to go to war? And how should a war be justly fought? In answering these questions, just war theory is traditionally divided into two parts, jus ad bellum (justice of war) and jus in bello (justice in war). There are six criteria of jus ad bellum which apply to a state considering whether to go to war. Jus ad bellum is traditionally held to be the exclusive domain of governments, not 
individual combatants. Individual combatants are neither held morally culpable if they fight in a war that does not meet these criteria nor are they given the prerogative to refuse to fight on such grounds. This is the crux of how combatants are disempowered. In contrast, individual combatants are only morally culpable if they violate the separate criteria of jus in bello, which prescribe how war may be conducted. In this chapter I will also elucidate just war theory by framing it in relation to prima facie duties.

\section{Chapter Two: Selective Conscientious Objection and the Moral Equality of Combatants}

In this chapter I will introduce the topics of selective conscientious objection (SCO) and the moral equality of combatants (MEC). Selective conscientious objection is a refusal to participate in a specific war due to reasons of conscience. It is a modification of universal conscientious objection (UCO) which is a refusal to participate in all wars due to reasons of conscience. Many nations, including the US, legally allow UCO but not SCO. The policy debate regarding SCO considers whether combatants should have a legal right to not participate in an unjust war. The debate within just war theory considers whether combatants should have a moral duty or moral privilege to not participate in an unjust war. Addressing both debates, I ultimately argue for a moral duty and a legal right.

MEC is the idea that combatants are moral equals regardless of the justice of their state's cause. The basic idea is that, since combatants are not required (and perhaps not even permitted) to act on their assessment of the justice of their state's cause, they cannot be blamed for fighting in an unjust war effort, and they do not thereby renounce any of the privileges or immunities afforded to other combatants. 
SCO and MEC affect the moral empowerment of combatants in numerous ways. If combatants are to consider the justice of the wars in which they fight, a policy allowing SCO would provide them a way to act upon their beliefs without risking imprisonment. Denying MEC would make room for the possibility that the justice of a state's cause could affect the rights and privileges of a combatant. For instance, a combatant in an unjust military venture might not have the moral privilege to direct deadly force against a just combatant.

I will summarize key portions of the current and historical debate regarding SCO and MEC. To provide contrast for my later top-down argument, I will highlight bottom-up arguments for SCO and against MEC which focus on individual rights or duties. These bottomup arguments for SCO are often conjoined with bottom-up arguments against MEC.

\section{Chapter Three: Henry Shue’s “Institutional Turn in Thinking about Human Rights”1}

The purpose of Chapter Three is to introduce Henry Shue's tripartite framework of correlative duties and discuss its critics. Shue's idea is that if rights are to be more than mere manifesto rights, we need a way to ensure they are "socially guaranteed against standard threats." ${ }^{2}$ Shue believes, "What people want and need ... is the protection of their rights." ${ }^{3}$ To effect this protection Shue dissolves the supposed dichotomy of positive and negative rights/duties. For any basic right, Shue claims that there are duties to avoid rights violations, duties to protect from rights violations, and duties to aid those whose rights have been violated. ${ }^{4}$ In the case of physical security, a duty to avoid simply rules out assault, murder, etc.

\footnotetext{
${ }^{1}$ Henry Shue, "Afterword," to Basic Rights: Subsistence, Affluence, and U. S. Foreign Policy, 2nd ed. (Princeton: Princeton University Press, 1996), 166.

${ }^{2}$ Henry Shue, Basic Rights, 1st ed. (Princeton: Princeton University Press, 1980), 13.

${ }^{3}$ Shue, Basic Rights, 38.

${ }^{4}$ Ibid., 52.
} 
A duty to protect would require the creation of formal social institutions that prevent violations, including police, courts, prisons, etc. ${ }^{5}$ Aid is "positive action by society to restore [rights] when avoidance and protection both fail," such as helping an assault victim recover. ${ }^{6}$ Shue summarizes his tripartite framework:

The fulfillment of a basic right [...] involves at least the following kinds of duties:

I. To avoid depriving.

II. To protect from deprivation

1. By enforcing duty (I) and

2. By designing institutions that avoid the creation of strong incentives to violate duty (I).

III. To aid the deprived

1. Who are one's special responsibility,

2. Who are victims of social failures in the performance of duties (I), (II-1), (II-2) and

3. Who are victims of natural disasters. ${ }^{7}$

The most powerful part of Shue's theory involves Type II-2 duties to protect. These are divided into Type II-1 duties of enforcement and Type II-2 duties of institutional design. Shue now espouses a more positive interpretation of Type II-2 duties than the above-quoted list suggests. In a new afterword, in the second edition, he writes, "I gave the creation of better institutions designed to ensure that rights are respected in the first place less attention than I now believe it deserves. Worse, I conceived of duty II-2 much too negatively and much too narrowly." ${ }^{8}$ He adds, "Duties to protect [should be], broadly interpreted to include the design and maintenance of institutions that make it as easy as possible for people to honor their duties not to deprive others of the enjoyment of their rights or, put differently, as hard as possible to

\footnotetext{
${ }^{5}$ Ibid., 37-38.

6 Ibid., 53.

${ }^{7}$ Ibid., 60.

${ }^{8}$ Shue, "Afterword," 159.
} 
commit, and to get away with deprivations." ${ }^{9}$ Based on this and other evidence, I reinterpret Type II-2 duties "as ones that protect from deprivation by designing institutions that make the right protected by duty (I) as secure as reasonably possible against violations."

\section{Chapter Four: Shue's Tripartite Framework and Just War Theory}

In this chapter, I will apply Shue's Tripartite Framework to just war theory. Initially, I will integrate the two by placing the duties recognized by traditional just war theory within Shue's framework, but ultimately conflicts will appear, revealing the structure of a top-down argument for SCO and against MEC. Just war theory assigns duties to states and combatants, and these duties are supposed to uphold the rights that it claims to protect. However, when it comes to the Type II-2 duties of states, problems arise. States have a Type I duty to avoid aggression and a related Type II-2 duty to design institutions that make the right protected by duty (I) as secure as reasonably possible against violations.

If SCO were legally allowed, it would give rise to a powerful impediment to state aggression. If combatants ordered to fight an aggressive war objected, this would make fighting aggressive wars more difficult. The difficulties posed by such objections would help to dissuade states from starting aggressive wars. Of course, other measures might be imagined that would help to protect the international community against aggression. I will briefly discuss some of these other measures. I will further argue that just war theory should morally require SCO as a means to make the right against aggression as secure as reasonably possible against violations. Contrary to the prevailing view of just war theory, combatants have duties to avoid

\footnotetext{
${ }^{9}$ Ibid., 173.
} 
and duties to protect that are necessary to fulfill state rights. This will have a cascade of effects which will modify the prevailing view of just war theory and morally empower combatants.

\section{Chapter Five: Responding to Objections and Further Refinements}

In this chapter I will respond to objections and offer further refinements to my theory.

The largest concern is that empowering combatants will endanger state rights and make it more difficult for a state to defend itself. I will argue that this is not the case and offer refinements to mitigate the danger. I will also discuss how to increase the effectiveness of selective conscientious via combatant education. I will give guidance as to what combatants should consider when contemplating SCO and how they should act when objecting. I will then respond to concerns about the fairness of SCO. Finally, I will detail a process to ensure the effective and fair enforcement of a legal allowance to SCO.

\section{Concluding Thoughts}

I will consider how my conclusions compare to Henry Shue's writings on just war theory, ultimately determining the two are consistent. In sum, the changes discussed in this dissertation will morally empower combatants and thereby reduce the likelihood of aggressive wars. 


\section{Chapter One: Just War Theory}

Introduction

In this chapter, I will introduce just enough just war theory upon which to build the rest of the project. I will explain its purpose and compare it to its rivals. I will then introduce the main divisions and discuss the key components of each. I will also discuss the prevailing view. Following this I will explicate the concept of prima facie duties and propose criteria for both when and how to override prima facie duties. Following James Childress, I will demonstrate how prima facie duties can be used to "illuminate" the general moral principles backing just war theory. ${ }^{1}$ In the second part of this chapter, I will discuss specific instances of what combatant empowerment entails.

\section{The Basics of Just War Theory}

In the first chapter, I will present the key components of what I will refer to as the prevailing view of just war theory. It is widely accepted that Michael Walzer gives a reliable presentation of the central features of the prevailing view, so I will rely quite heavily on his seminal work, Just and Unjust Wars, in writing this chapter. ${ }^{2}$ Just war theory provides moral guidance for how states and individuals should conduct themselves regarding warfare. All varieties of just war theory state specific conditions under which it can sometimes be morally justified to fight a war. All varieties also direct what methods of fighting are acceptable and what are not. This is in opposition to just war theory's rivals; pacifism and realism. In contrast to just war theory, pacifism states that no war can be justified. Realism differs from just war

\footnotetext{
1 James Childress, "Just-War Theories: The Bases, Interrelation, Priorities, and Functions of Their Criteria," Theological Studies, 39:3 (1978): 429 \& 428-435.

${ }^{2}$ Michael Walzer, Just and Unjust Wars, $2^{\text {nd }}$ ed, (United States: Basic Books, 1992).
} 
theory in denying that morality even applies to warfare. Thus, a state does not need to morally justify its reasons for fighting, which will likely produce more wars. Also, once fighting has begun, realists would not accept moral constraints on actions within war. In contrast, just war theory restrains "both the incidence and destructiveness of warfare." ${ }^{3}$

In doing this, just war theory gives answers to two questions: When is it just to go to war? And how should we fight? In answering these questions, just war theory is traditionally divided into two parts, jus ad bellum (justice of war) and jus in bello (justice in war). ${ }^{4}$ The criteria of jus ad bellum apply to a state considering whether to go to war. Summarized below are the traditional principles of jus ad bellum:

Just Cause: A state must have a just cause for warfare such as responding to aggression either in self-defense or other-defense. Under certain conditions, the "normative" selfdefense of a preemptive attack is also allowed.

Right Intention: A state must have a moral motive for going to war, although it is acceptable for other motives to be present.

Public Declaration of War by a Proper Authority: War must be publically declared to both one's enemy and one's own state. This warns the enemy of what is to come and gives them a last chance to stop aggressing. War must be declared by a head of state, not by private individuals.

Last Resort: Other means must be tried first, but this does not need to be taken too literally. In other words, "States ought not to be hasty in their resort to force." For instance, if an invasion is underway, a state is not obligated to attempt to negotiate.

Probability of Success: A state must have a reasonable probability of success. The aim of this "is to bar lethal violence which is known in advance to be futile." However, long odds have been overcome before, so it should not be taken too stringently.

Proportionality: "A state considering a war must weigh the expected universal (not just selfish national) benefits of doing so against the expected universal costs." ${ }^{15,6}$

\footnotetext{
${ }^{3}$ Brian Orend, The Morality of War (Toronto: Broadview Press, 2006), 31. See also David Fisher, Morality and War (Oxford: Oxford University Press, 2011), 66.

${ }^{4}$ Recently jus post bellum, justice after war, has also become an important topic of philosophical discussion. Despite this, I will for the most part focus on other issues in this project.

${ }^{5}$ Orend, War, 31-65 \& 74-78.

${ }^{6}$ Calculating proportionality is no easy task especially considering human lives and monetary costs are balanced against independence (Orend, War, 60). Walzer calls it a "gross truth" (Walzer, Wars, XVI), and Orend notes it is easier to recognize disproportionality than "precisely defining" proportionality (Orend, War, 60).
} 
The most common view is that all the above principles are jointly necessary and sufficient for meeting jus ad bellum, but the violation of any one of the items is all that is required to fail to meet jus ad bellum. Brian Orend supports this view, as does David Fisher, who states, "It is permissible to embark on a war if and only if" all the jus ad bellum criteria are met. ${ }^{7}$ However, Dan Zupan denies that proper authority is necessary, and James Childress considers possibilities ranging from "each is necessary and all are collectively sufficient" to the criteria being "rules of thumb." 8

In claiming proper authority is not necessary, Zupan gives the counterfactual scenario where a mercenary group would be justified in intervening to prevent the Rwandan genocide. In this case, he argues that a proper authority no longer existed as Rwanda had devolved into a state of nature. ${ }^{9}$ Of course, this ignores the fact that proper authority existed in the states that stood by and let the genocide occur. I think a better interpretation is not that proper authority is not needed, but that in the event of genocide ignored by the major world powers, proper authority may be reinterpreted to include any entity that is able and willing to help. I prefer this second explanation as it retains the proper authority requirement which condemns "private wars" but still leaves some flexibility to account for situations such as that which occurred in Rwanda. However, a much better counterfactual scenario would be if bystander states had intervened. Relatedly, a justified revolution would also need to be led by a proper authority. Such an authority would not be the head of a state but instead could be the head of a group who desires to become a legitimate state.

\footnotetext{
${ }^{7}$ Orend, War, 32 \& 61. Fisher, War, 66.

8 Dan Zupan, "The Logic of Community, Ignorance, and the Presumption of Moral Equality: A Soldier's Story," Journal of Military Ethics, 6:1 (2007): 42. James Childress, "Just-War Theories," 441-442.

${ }^{9}$ Zupan, "Logic," 42.
} 
A difficultly with considering the above principles as only needing to be approximately met or as mere rules of thumb, is that we are left without a standard to judge whether a war is justified other than utility. The above principles are in place to defend rights, and it will be difficult to support a rights based conception of just war theory if utility is the standard. One case Childress mentions that may avoid this problem is if the principles are considered to be prima-facie duties. I will later discuss how the above principles are already in place to override other prima facie duties. Adding an additional override is possible, but this adds a great deal of complexity.

My brief descriptions of the traditional principles do not do justice to all that these elements entail, nor do they reflect the fact that within just war theory these items are still being interpreted and defined. The theorist from whom I quoted the jus ad bellum principles, Brian Orend, is fairly supportive of the modifications to just war theory that I will propose later in this dissertation. To avoid accusations of using only sources friendly to my views, I would like to mention that these elements are upheld by many other theorists including Paul Christopher, who is extremely antagonistic to my ultimate conclusions, and David Fisher, who holds a position somewhere between Christopher and me. ${ }^{10}$ Of course none of the theorists mentioned created these elements but rather they reflect the work of many thinkers over many years. That some theorists do not endorse a specific ad bellum criterion makes it difficult to argue they are all necessary. Of course one can state that, of the criteria they do endorse, all are necessary. That these principles are debated or that debates could result in small changes to the included principles will not invalidate my overall project. For now, I will utilize the

\footnotetext{
${ }^{10}$ Fisher, War, 66-76. Paul Christopher, The Ethics of War \& Peace: An Introduction to Legal and Moral Issues, $2^{\text {nd }}$ ed. (Upper Saddle River: Prentice Hall, 1999), 81-91. Christopher omits 'right intention' (88).
} 
prevailing (although not unanimous) and more parsimonious view, that all the above principles are necessary.

A key concept within jus ad bellum is aggression. Walzer states, "Every violation of territorial integrity or political sovereignty of an independent state is called aggression."11 Walzer grounds just war theory in rights, specifically in states' rights to territorial integrity and political sovereignty similar to individuals' rights to life and liberty. ${ }^{12}$ The rights of territorial integrity and political sovereignty "belong to states, but they derive ultimately from the rights of individuals, and from them they take their force." ${ }^{13}$ That an armed attack on a populated area or the overthrow of a legitimate government would have an adverse effect on an individual's life or liberty is fairly obvious.

Committing aggression violates the rights of a state and usually also its citizens. I add the caveat of "usually" because it is possible to violate state rights without directly violating individual rights such as by invading a small uninhabited portion of another state. On my view (and also Walzer's), although derived from individual rights, violations of state rights are not necessarily reducible to violations of individual rights. However, they often do violate individual rights or at least pose a significant threat to such rights. For example, if the above mentioned small uninhabited territory is a buffer zone, then the invasion of that buffer zone poses an increased risk of an invasion to the areas protected by that buffer zone. In general, state rights are needed to support individual rights, and an analogy with individual rights helps justify state rights.

\footnotetext{
${ }^{11}$ Walzer, Wars, 52.

12 Ibid., 53-54.

${ }^{13}$ Ibid., 53.
} 
There are some such as Jeff McMahan who subscribe to a reductive strategy and claim "that national defense is reducible to the defense of individuals" in contrast to an analogical strategy that "an act of self-defense by the state [...] is analogous to an act of self-defense by an individual."14 That Walzer derives state rights from individual rights, initially suggests he holds something like a reductive view. However, Walzer relies upon the "domestic analogy" ${ }^{15}$ and in fact, the term is often credited to him. ${ }^{16}$ Elsewhere, Walzer writes, "The international standing of government derives only indirectly from their standing with their own citizens." ${ }^{17}$ David Rodin demonstrates how Walzer could be read as supporting either view. ${ }^{18}$ Ultimately, both Rodin and McMahan argue that Walzer's support for MEC is incompatible with the reductive view. ${ }^{19}$ If just combatants have not forfeited their rights (as is the case with individual selfdefense), then when they are attacked by unjust combatants they are being attacked unjustly. However, MEC allows unjust combatants to attack just combatants.

It is beyond the scope of my project to extensively defend a stance on either the reductive or analogical view. That this issue is heavily debated suggests that an approach which can bypass the debate could be useful. I would like to acknowledge that my argument can speak to either side. On the reductive view, my state rights (top-down) approach is ultimately reduced to individual rights. However, when speaking to those who take an analogical approach or only care to discuss state rights, my approach has the advantage of using terminology common to both sides. I do not rely on state rights being reducible to individual

\footnotetext{
${ }^{14}$ Jeff McMahan, “War as Self-Defense,” Ethics and International Affairs, 18:1 (2004): 75.

${ }^{15}$ Walzer, Wars, 58.

${ }^{16}$ David Rodin, War and Self Defense (Oxford: Oxford University Press, 2002), 108; Orend, War, 48.

${ }^{17}$ Michael Walzer, "The Moral Standing of States," Philosophy and Public Affairs, 9:3 (1980): 212.

${ }^{18}$ Rodin, War, 122-162.

${ }^{19}$ Rodin, War, 128-129; Jeff McMahan, "The Sources and Status of Just War Principles." Journal of Military Ethics, 6:2 (2007): 98-99.
} 
rights to make my point. I will speak to all just war theorists whether they subscribe to an analogical view, a reductive view, or something else.

I should note that I uphold a distinction between "violate" and "infringe." I follow McMahan, who writes, "When one [...] permissibly acts against a right, [...] one infringes that right, whereas when one impermissibly does what another has a right that one not do, one violates that right." ${ }^{20}$ Self-defense would merely infringe, rather than violate, an aggressor state's right to territorial integrity or political sovereignty.

In addition to self-defense, humanitarian interventions are another case where it is morally permissible to infringe state rights. ${ }^{21}$ In the case of a justified intervention, "selfdefense" against it would not be justified. ${ }^{22}$ In such a case, the humanitarian intervention is actually responding to internal aggression (such as genocide) and is therefore only infringing a right to territorial integrity and political sovereignty. However "defending" against a just humanitarian intervention is aggressive as there is no just polity to defend. Instead of infringement, another way to consider the issue is that a state that is aggressive (externally or internally) forfeits its rights to political sovereignty and territorial integrity. ${ }^{23}$ In this view, an aggressive state no longer has the above rights to be infringed. However, individual citizens have not generally forfeited their rights to life and liberty just because their state has forfeited state rights. This is another reason not to reduce state rights directly to individual rights. What rights individuals retain in times of war will be discussed shortly.

\footnotetext{
${ }^{20}$ Jeff McMahan, Killing In War (New York: Oxford University Press, 2009), 10.

${ }^{21}$ Walzer, Wars, 86.

${ }^{22}$ However, an individual's acts of defense may be excusable if they are ignorant (and not culpably so) of the justified intervention and instead believe their state is being aggressively attacked.

${ }^{23}$ Orend, War, 37-40.
} 
Jus ad bellum is traditionally held to be the exclusive domain of governments, not individual combatants. It is the state that must meet the above criteria, and individual combatants are neither held morally culpable if they fight in a war that does not meet these criteria nor are they given the prerogative to refuse to fight on such grounds. This is the crux of how combatants are disempowered. As a proponent of the prevailing view, Walzer states, "We draw a line between the war itself, for which soldiers are not responsible, and the conduct of the war, for which they are responsible, at least within their own sphere of activity."24 In contrast to expectations regarding jus ad bellum, individual combatants are morally culpable if they violate the separate criteria of jus in bello, which prescribe how war may be conducted. ${ }^{25}$ These criteria include the provision that combatants can be directly targeted, yet have a right to not be targeted with unnecessary or disproportionate force. These restrictions are positively expressed as the principles of necessity and proportionality, and they are designed to exclude "purposeless or wanton violence." ${ }^{26}$ Walzer references Sidgwick, stating that the principle of necessity forbids "any mischief that does not tend materially to the end [of victory]," and the principle of proportionality forbids "any mischief of which the conduciveness to the end is slight in comparison with the amount of mischief."27

In the simplest form, combatants are distinguished from non-combatants by the fact that combatants "bear arms" and "pose a danger to other people." ${ }^{28}$ This is known as the principle of discrimination, and it grants non-combatants further protection stating that they

\footnotetext{
${ }^{24}$ Walzer, Wars, 38-39.

${ }^{25}$ States also have a responsibility to uphold jus in bello criteria.

${ }^{26}$ Walzer, Wars, 129.

27 Ibid.

${ }^{28}$ Ibid., 145.
} 
may not be killed directly, intentionally, or disproportionately. ${ }^{29}$ The prohibition on direct killing is stated by Walzer: non-combatants "can never be the objects or the targets of military activity." ${ }^{30}$ However, following the Doctrine of Double Effect (DDE), Walzer would allow the indirect killing of non-combatants under the below four conditions:

1) The act is good in itself or at least indifferent, which means for our purposes, that it is a legitimate act of war.

2) The direct effect is morally acceptable-the destruction of military supplies, for example, or the killing of enemy soldiers.

3) The intention of the actor is good, that is, he aims only at the acceptable effect; the evil effect is not one of his ends, nor is it a means to his ends.

4) The good effect is sufficiently good to compensate for allowing the evil effect; it must be justifiable under Sidgwick's proportionality rule. ${ }^{31}$

Walzer later adds to condition three, "and, aware of the evil involved, he seeks to minimize it, accepting costs to himself." ${ }^{32}$ Specifically, condition three excludes the intentional killing of non-combatants and condition four excludes the disproportionate killing of non-combatants.

Although Walzer does not specifically discuss prohibited weapons, other theorists do. ${ }^{33}$ For the most part, however, the reason prohibited weapons are classified as such is that they fail to uphold elements of jus in bello. For example, landmines fail to discriminate in the near term and glass-filled bullets fail to discriminate in the long term (long after ceasing to be a combatant, the glass shards can still cause further injury to someone previously shot). ${ }^{34}$ Also, within jus in bello, the concept of benevolent quarantine governs what rights prisoners have, most notably against being killed or tortured. In gaining these rights, prisoners lose the right to

${ }^{29}$ Ibid., 151-159. Orend, War, 262.

${ }^{30}$ Walzer, Wars, 151.

31 Ibid., 153.

32 Ibid., 155.

${ }^{33}$ Brian Orend, Michael Walzer on War and Justice, (Cardiff: University of Wales Press, 2000), 122-123. See also, Christopher, War, 96-97.

${ }^{34}$ Ibid., 122-123 
kill enemy combatants. ${ }^{35}$ As prisoners are not to be treated as combatants, benevolent quarantine can be included under the previously mentioned principle of discrimination.

Although violations of jus in bello occur frequently, they are also frequently deplored. For example, consider public reaction to the events at My Lai or Abu Ghraib. That these events only need be referenced by a location demonstrates the power of jus in bello within the public consciousness, even by those who have neither heard the phrase nor heard of just war theory. Furthermore, combatants are morally empowered to object to violations of jus in bello if ordered to commit such crimes. Walzer states, "Despite their oath [to obey], we blame them for crimes that follow from 'unlawful' or immoral obedience." ${ }^{36}$ Walzer allows the excuse of duress for those who are threatened with execution, but he also praises a German soldier who refused to execute prisoners and was promptly executed along with the prisoners. ${ }^{37}$

\section{Prevailing View or Orthodoxy?}

I have so far described Walzer's view of just war theory as more or less representing the prevailing view, but more explanation is needed. Some theorists refer to Walzer as orthodox, and in an interview Walzer himself stated, "My book has become something of the orthodox account." ${ }^{38}$ Other theorists deny that Walzer is orthodox. ${ }^{39}$ Jeff McMahan refers to Walzer's

\footnotetext{
${ }^{35}$ Walzer, Wars, 46, 177. Orend, War, 110. Christopher, War, 95-96.

${ }^{36}$ Walzer, Wars, 311.

${ }^{37}$ Ibid., 313-316.

${ }^{38}$ Roger Wertheimer, "Introduction," to Empowering Our Military Conscience Transforming Just War Theory and Military Moral Education, edited by Roger Wertheimer, 1-11, (Famham: Ashgate Publishing Group, 2010), 6. Jordy Rocheleau, "License to Kill: Rethinking War's Ethical Boundaries" Radical Philosophy Review, 13:2 (2010), 203. "Michael Walzer: The Art Of Theory Interview" accessed May 5, 2015, http://www.artoftheory.com/michaelwalzer-the-art-of-theory-interview/.

${ }^{39}$ Anthony Coates, "Is the Independent Application of jus in bello the Way to Limit War?," in Just and Unjust Warriors, edited by David Rodin and Henry Shue, 176-192, (Oxford: Oxford University Press, 2008$), 176$.

Reichburg, "Just War and Regular War: Competing Paradigms," in Just and Unjust Warriors, edited by David Rodin and Henry Shue, 193-213, (Oxford: Oxford University Press, 2008), 193-195. Whitley Kaufman, "Book Review of McMahan, Jeff: Killing in War," Ethics 120:2 (2010): 399.
} 
view as "dominant," "reigning," "mainstream," or as "the leading contemporary exponent of the theory of just war." ${ }^{40}$ Brian Orend describes Walzer's Just and Unjust Wars as "the fundamental contemporary reference, which everyone 'in the business' must read and understand. ${ }^{41}$ Despite these endorsements, just war theory has a history that spans over two millennia, including many different cultures and many different viewpoints. ${ }^{42}$ This makes it difficult to point to a specific orthodoxy or claim a single theorist represents that orthodoxy. At the start of this project I mistakenly considered Walzer to represent the orthodox view and later learned that despite my mistake, I was in good company. In countering Walzer, Jeff McMahan confesses that he thought of himself as revolutionary until he was enlightened that he was reactionary. ${ }^{43}$ In Chapter Two, as we begin to focus on more specific issues, we will see just how various the viewpoints can be both in historical and contemporary debates.

Nonetheless, not all is debated; David Fisher writes, "Within this shifting tradition there is a reasonably settled core of principles, built up and crafted over the centuries, which are designed to provide guidance to our thinking about war.." ${ }^{44}$ I do not wish to debate exactly who or what is orthodox, and as such I have chosen to use "prevailing" to convey the contemporary influence of Walzer's view while avoiding the claim that he is orthodox.

\section{Overriding Prima Facie Duties}

To elucidate just war theory, I will reference prima facie duties. By treating some of the duties of just war theory as prima facie duties, I will be able to resolve apparent conflicts that

\footnotetext{
40 Jeff McMahan, "The Morality of War and the Law of War," in Just and Unjust Warriors, edited by David Rodin and Henry Shue, 19-43, (Oxford: Oxford University Press, 2008), 21 \& 43. McMahan, Killing, 4, $11,204$.

${ }^{41}$ Orend, War, 24.

${ }^{42}$ Historic notables include Augustine, Aquinas, Grotius, Suarez, Vattel, Vitoria, and Hugo Grotius. See Orend, Walzer, 87.

${ }^{43}$ McMahan, Killing, 238 (footnote, 26).

${ }^{44}$ Fisher, War, 64.
} 
would be unresolvable for absolute duties. For example, if there is an absolute duty to protect non-combatant life and liberty, it would be incompatible with almost any duty to protect against aggression, as it is nearly impossible to fight a war without endangering noncombatants. Are jus in bello rights an adequate accommodation of the right to life and liberty in times of war. Clearly a right to life and liberty is much more robust than the rights prescribed by jus in bello. How can we justify this accommodation? Can we still base just war theory on human rights, or by downgrading rights are we effectively disregarding them? I will consider this question in regard to non-combatants, and I will turn to the concept of prima facie duties. I will give examples of prima facie duties applied both within and outside of warfare, and I will explicate the concept by referencing override criteria, mitigating criteria, and positing the existence of resolution criteria.

A lesser of two evils (LOTE) argument would run something like this. A right to life and liberty can be reduced to jus in bello rights because otherwise there is no way to fight a war against aggression, and no way to uphold rights. Although reducing rights from the more robust life and liberty rights to jus in bello rights is harmful, in many cases it is more harmful to allow aggression and its corresponding rights' violations to go unchecked. Also, although this argument can be used to justify reducing the rights of an aggressor state's combatants and noncombatants, more will be needed to explain why the rights of a victim state's combatants and non-combatants are also reduced.

A concern is that just war theory is meant to be resistant to further downgrading of rights. For example consider the following arguments;

1. If we refuse to take prisoners, we will save resources which will end the war sooner. 
2. We could end the war faster by torturing the enemy politicians' children.

3. We could capture the enemy's port with very few enemy casualties, but if we gruesomely kill all the combatants defending the port, the enemy may surrender.

These and similar arguments about rights' violations may not achieve their desired ends, but they are the kinds of arguments that will likely be acted upon if LOTE arguments are given too much traction. Despite a LOTE argument justifying some wars at the macro level, at the micro level there are still rights to be upheld, and we do not want LOTE arguments overriding those rights within war. What we want is a system that allows rights to be overridden for certain purposes at the macro level, but that still upholds the existence of other rights at the micro level. JWT is such a system, but can it be supported by general ethical principles? My response to this sort of problem is to consult a domestic analogy.

\section{Gas Line Domestic Analogy}

Borrowing from Walzer: "When the gas company works on the lines that run under my street, I have a right that its workmen observe very strict safety standards. But if the work is urgently required by the imminent danger of an explosion on a neighboring street, the standards may be relaxed and my rights not violated." ${ }^{45}$ As Walzer describes it, the case is distributing the danger (albeit a reduced danger) from a neighboring street to one's own. I would like to back up and consider a case where the group at risk from the response is the same as the one already in danger.

Imagine that the imminent danger will only affect my street, and the relaxed standards only increase the risk on my street. In such a case my street is trading the danger of an explosion due to the emergent situation, for the (presumably less likely) danger of an explosion

\footnotetext{
${ }^{45}$ Walzer, Wars, 156.
} 
(or other harm) due to relaxed safety standards in response to the potential explosion. The relaxed standards are the lesser of two evils. As far as rights are concerned, the safety standards are there to protect life, but in this case strict adherence is more likely to endanger life. The rational choice is to choose the lower risk. There does not seem to be an issueassuming of course that the proportionality calculation for the relative risks has been done correctly.

The scenario becomes more complicated when the risks are spread among different groups. As Walzer gives the scenario, it is a neighboring street that faces the risk of an explosion, but it is one's own street that faces a risk from the relaxed safety standards. Each group has rights that appear to conflict with the other group's rights. How do we determine which rights have precedence? I won't pretend to settle the matter, but if the residents on the non-threatened street are completely immune from any increased risk, then the gas company would be unable to attempt to prevent a disaster. If we think that the gas company should be able (in at least some circumstances) to work to prevent an explosion, then we must acknowledge that residents can't have a right of complete immunity from the danger posed by the gas company.

All the residents in the scenario have a right to life and liberty, but even before the emergency, this right does not guarantee complete immunity from danger posed by the gas company or their products. The emergency then increases the risks that some residents face. Different manners of speaking could be to say that rights are downgraded, accommodated, or reinterpreted for a specific circumstance. However, at no point are any specific person's or group's rights intentionally sacrificed for another. The rights are still equal, but based on moral 
luck driven by the difficult circumstances, the risks different individuals face become unequal as we attempt to honor the rights during the civil emergency. Certain people face a higher risk of injury from the relaxation of safety standards, and others stand to have their risk of injury decreased.

However, just because the presumption against relaxing safety standards can be overridden in the case of an emergent explosion, this does not mean that anything can be done in response. There is guidance we must follow when executing the override, but first we need to establish criteria that might be used to determine that the presumption can be overridden.

Most would say it is wrong to relax previously established safety standards out of sheer laziness. There must be a compelling reason, such as preventing an explosion. Furthermore, it would also be wrong for the gas company to claim they are trying to prevent an explosion when the real reason is laziness. Relaxing the safety standards has to be the only option available. It would be reckless to relax safety standards when the explosion could be otherwise prevented. There has to be a reasonable likelihood that reducing the standards will fix the problem. It would be foolish to reduce standards and endanger one street when it is not likely to help the other street. Also, the danger posed by relaxing the safety standards must be proportional to the danger imposed by the initial risk of an explosion. The relaxation of safety standards should not be executed in secret, and the public should be warned so they can react accordingly.

Finally, since the stakes are so high, only those with expertise such as government or gas company officials should make these decisions and respond to the emergency, not an ad hoc group of perhaps well-intentioned citizens who may bungle the response. If these criteria are met, then it is appropriate to relax safety standards in order to prevent the explosion. One 
should see the familiar criteria of jus ad bellum at work behind the above discussion. In a few pages I will discuss the significance of this.

So far we have established that it is sometimes appropriate to override safety standards, but that is not all the work that needs to be done. We don't just declare all safety standards null and void. We need to make sure the right standards are overridden in the right way. I will borrow the jus in bello standards of necessity, proportionality, and discrimination to help consider the issue.

Necessity: Is the specific reduction of safety standards required to prevent the disaster? It would be foolish to relax a standard about workers smoking while conducting repairs. Such a relaxation is not necessary for preventing the explosion (and actually increases the risk). Relatedly it would be foolish to relax the standards further than necessary. Something can fail the requirement of necessity for two reasons. It is not needed to accomplish the desired good because it does not in fact accomplish the desired good. Or, it is not needed to accomplish the desired good, because something less harmful could do so.

Proportionality: Will the bad effects of the response be proportionate to the danger averted? Although we have already determined that a general relaxing of safety standards is proportional to the danger averted, we need to consider if each act of relaxing safety standards is proportional in its contribution towards averting the danger. For example, digging equipment that works faster but at a higher risk of causing an explosion may not be proportionate. Digging equipment that works faster, but that increases the risk of minor injuries to residents, may be proportionate. If multiple options are available and proportionate, necessity would require that we choose the one that does not result in needless risk. 
Discrimination: One other factor when overriding duties is who is affected. We should not necessarily increase the risks equally for everyone. Those more likely to face increased risks are those whose increased risks will have the biggest impact (those who live near where work will be done) and those with professional obligations such as gas company workers and first responders. The rights of employees and responders to not be exposed to certain risks are lower, but this does not mean they should be exposed to disproportionate or unnecessary risks. Discrimination means we treat different categories differently; we do not infringe the rights of just anybody. Just because we have decided that some rights will be infringed does not mean that it is open season to infringe everyone's rights.

After the emergency has been resolved, the gas company needs to announce an all clear as well as repair any damage done and determine if action is needed to prevent similar emergencies in the future. In the above gas line scenario, all of this may be decided at a faster pace that I can compose this. Because of this, such an analysis may sound too fanciful, but when planning emergency responses, the gas company is not burdened by time-critical decisions and can conduct a more thoughtful analysis. ${ }^{46}$ I would now like to elucidate the general principles which support the downgrading of rights seen within just war theory and the gas line analogy.

\section{Overriding Prima Facie Duties}

I have shown that the principles similar to jus ad bellum and jus in bello principles can be useful in a situation other than war. More specifically they are useful in situations with conflicting rights or duties. This is not coincidental, and just war theory is actually an

\footnotetext{
${ }^{46} \mathrm{I}$ admit to having no special knowledge about gas line repairs.
} 
instantiation of a more general principle. Malham Wakin shares that the argument used to justify war is the same as the argument to break a promise in order to help at the scene of an accident. Wakin considers promise keeping and assisting accident victims to be examples of "universal obligations" which can conflict. He contrasts them with "absolute obligations" which "must always be observed and could never be in conflict with any other absolute obligations." ${ }^{47}$ If we view the duties to protect and the duties to avoid as universal instead of absolute, we can make sense of the need to sometimes downgrade rights.

James Childress expresses a view similar to Wakin's, arguing that just war theory attempts to balance competing prima facie duties. Childress states, "We formulate and use criteria that are analogous to those that determine whether a war is just and justified whenever we face conflicting obligations or duties, whenever it is impossible to fulfill all the claims upon us, to respect all the rights involved, or to avoid doing evil to everyone." ${ }^{48}$ He further adds that when we override a prima facie obligation, the overridden obligation leaves behind what Robert Nozick calls "moral traces." ${ }^{49}$ For example if I have to break a promise, "I should at least explain the situation to the promisee, ask him to not hold me to the promise, apologize for breaking it, and even try to make it up to him later." ${ }^{50}$ We can see the cousins of public declaration, last resort, and right intent in these "moral traces."

I argue that jus ad bellum is a specific implementation of what may more generally be called "prima facie duty override criteria" or override criteria for short. The conflicting prima facie duties are a duty to not violate/infringe the rights of another state or its citizens, and a

\footnotetext{
${ }^{47}$ Malham Wakin, Integrity First, (Lanham: Lexington Books, 2000), 124.

48 Childress, "Just-War," 429.

${ }^{49}$ Quoted in Childress, "Just-War," 431.

50 Ibid., 432.
} 
duty to protect the rights of one's own state and citizens. ${ }^{51}$ From Childress's perspective, the conflicting prima facie duties are a duty not to "injure or kill others" and a duty "to protect the innocent from unjust attack, to restore rights wrongfully denied, or to reestablish a just order." ${ }^{52}$ Returning to the question of downgrading non-combatant life and liberty, the conflicting prima facie duties are a duty to not violate/infringe the life and liberty of noncombatants and a duty to defend one's own state against aggression. Regardless of which set of conflicting duties we use, as just war theory is currently conceived, there is a presumption against war which is only overridden by meeting the override criteria of jus ad bellum. ${ }^{53}$

I further argue that in addition to requiring that we meet specific standards to override prima facie duties, we also need to meet certain standards in the acts we commit when overriding the prima facie duties. Part of the "moral traces" left behind when we reduce the robust rights of life and liberty while prosecuting a just war are jus in bello rights. In general I will refer to these secondary standards as mitigating criteria. The goal of mitigating criteria is to reduce the damage done when overriding prima facie duties. ${ }^{54}$ The mitigating criteria help select which specific actions to take and guide how to execute those actions. Within just war theory, the mitigating criteria are the jus in bello criteria of necessity, proportionality, and discrimination. ${ }^{55}$ In the case of overriding a promise the mitigating criteria are primarily applied as part of the original override. Unlike war or some civil emergencies, overriding a promise is

\footnotetext{
51 If override criteria show that we are justified in overriding a duty not to violate, the action becomes an infringement of rights not a violation. On Orend's view, the override criteria judge those rights to be forfeited. I prefer the infringement view, because it reminds us that rights don't completely disappear and that the "moral traces" must be accounted for.

52 Childress, "Just-War," $435 \& 436$.

53 Ibid., 433 \& 436.

${ }^{54}$ This feature of prima facie duties can be used to argue against realists who claim that right conduct does not matter and that the only important moral feature is who started the war (Childress, "Just-War," 434).

${ }^{55} \mathrm{I}$ accept that there may be mitigating criteria in addition to those employed by jus in bello.
} 
not a large act composed of multiple smaller acts. Rather, each overridden promise is a onetime affair, so proportionality and necessity are already accounted for by the override criteria of proportionality and last resort. However discrimination still needs to be applied. An apology or explanation demonstrates discrimination in that it acknowledges that it is only this instance that is being overridden and the general duty to keep promises still exists. In effect, it says, "I am still trustworthy."

In addition to meeting the override and mitigating criteria, a state or individual also needs to meet resolution criteria in order to fully uphold the "moral traces." I will not specify resolution criteria, but I would like to posit their existence. Within warfare we can see the existence with the growing emphasis on jus post bellum (justice after war). Making up for an overridden promise demonstrates part of resolution criteria for that example.

A strength of override, mitigating, and resolution criteria is that it can explain why we have the just war theory criteria we do, even though such language was not present at the origins of just war theory. What I consider to be the most probable explanation of the origins of the various demands in just war theory is that they arose to combat the specific problems that each principle addresses. This view is upheld by both Paul Christopher and David Fisher as they trace the development of just war theory. ${ }^{56}$ For example, just cause addresses the problem of starting wars without a moral reason, and discrimination addresses the problem of directly targeting all the citizens of an enemy state.

However, in retrospect we can interpret and subscribe to overarching theories. For example, David Fisher and Brian Orend both subscribe to a theme of restraint. David Fisher

\footnotetext{
${ }^{56}$ Fisher, War, 66-76 \& 84. Christopher, Ethics, 7-64.
} 
writes, "The [just war] tradition recognizes that war causes immense human suffering and seeks to limit that suffering by restricting the occasions on which war may be begun and the manner in which it is conducted." ${ }^{57}$ Brain Orend writes, "The goal of just war theory is to restrain both the incidence and destructiveness of warfare.."58 "Goal" may be a misleading term as sophistry or a noble lie could all be used to meet such a goal. Ultimately just war theory should be concerned with determining the truth about when and how to fight even if that truth diverges from a "goal." However, as an overarching theory, restraint explains just war theory quite well. Another option held by both Michael Walzer and Brian Orend is that just war theory is in place to uphold human rights. Walzer claims, "the rules of war are grounded in a theory of rights" $^{\prime 29}$ Orend writes that just war theory is "a doctrine deeply aware of war's frightful dangers and brutal inhumanities, [and that] it seeks accordingly, to reduce those dangers, and purge those inhumanities, by insisting that belligerents respect human rights as best they can during the grim circumstances of war. ${ }^{\prime 60}$ Human rights, at least by that name, were not the aim of early just war theorists, but retrospectively it seems that human rights work well to explain the theory. In addition to restraint and human rights, another approach is to not give a reason for the criteria, but instead just assert them. This does not seem like a great option as understanding the reason behind the requirements may increase compliance.

I believe that prima facie duties are compatible with the restraint and human rights explanations, but also superior in that they not only encourage restraint for the sake of rights, but they go further by helping to explain how to resolve conflicts of rights. We consider rights

\footnotetext{
${ }^{57}$ Fisher, War, 66.

${ }^{58}$ Orend, War, 31.

${ }^{59}$ Walzer, Wars, 137.

${ }^{60}$ Orend, War, 31.
} 
and duties to be valuable, but realize that, in some cases, duties conflict with other duties.

There is a system to help decide which duties to emphasize and how to go about honoring the overridden duties. At no point do we declare that a duty ceases to exist; we just acknowledge that in some cases it may demand less than it does in more ideal circumstances.

So far duties have only been overridden for the sake of other duties, specifically a duty of self-defense or other-defense. However, some may consider a duty to promote the national interest or improve civilization to be worth overriding state rights. A quick counter in support of just war theory is to consider the egregious violations of rights that occurred as Nazi Germany pursued their national interest and attempted to "improve" civilization. The requirement of just cause to curb such abuses seems to be a good one. Assuming a state has a duty to promote their interest or improve civilization, the efforts must still stay within certain bounds. Analogously, in the domestic arena, we would not generally justify theft of property based on using the property to improve one's own interest, or even the well-being of the general population. We could imagine a scenario where a well-intentioned and disciplined state could sincerely aim to improve life in another state, but the risk of failure and the potential for abuse are high. Short of self-defense and other-defense, territorial integrity and political sovereignty are best respected as is required by just war theory.

So far I have given examples of how prima facie duties can be applied in warfare, civil emergencies, and promise keeping. If the tool of prima facie duties is powerful enough to explain the theoretical underpinnings of just war theory and handle other conflicting duties, might it also be useful elsewhere within just war theory? Based on the plausibility of using override, mitigating, and resolution criteria to handle the above situations, in a later chapter I 
will apply it to empowering combatants. But first, I will lay more groundwork by discussing specific instances of what combatant empowerment entails. 


\section{Chapter Two: Selective Conscientious Objection and the Moral Equality of Combatants}

\section{Introduction}

So far I have introduced combatant empowerment in general language. More specifically the empowerment is expressed in the currently debated issues of selective conscientious objection (SCO) and the moral equality of combatants (MEC). Selective conscientious objection is a refusal to participate in a specific war due to reasons of conscience. It is a modification of universal conscientious objection (UCO), which is a refusal to participate in all wars due to reasons of conscience. These theoretical distinctions are important in practice, because the current laws of many nations, including the US, allow UCO but not SCO. The policy debate regarding SCO considers whether combatants should have a legal right to not participate in an unjust war. The debate within just war theory considers whether combatants should have a moral duty or moral privilege to not participate in an unjust war. I will consider both debates and ultimately argue for a moral duty and a legal right.

MEC is the idea that combatants are moral equals regardless of the justice of their state's cause. The basic idea is that, since combatants are not required (and perhaps not even permitted) to act on their assessment of the justice of their state's cause, they cannot be blamed for fighting in an unjust war effort, and they do not thereby renounce any of the privileges or immunities afforded to other combatants. There are at least three ways I have discovered to conceive of MEC:

Base MEC: Combatants are moral equals regardless of the justice of their state's cause. If combatants are moral equals then combatants should have the same privileges and restrictions. 
Expanded MEC: In addition to the above, combatants that fight for an unjust side are thereby blameless, as long as they follow jus in bello.

Extreme MEC: In addition to the above, combatants that fight for an unjust side thereby exhibit no moral shortcomings whatsoever, as long as they follow jus in bello.

Is it possible to have the same moral privileges and restrictions, and still be blameworthy? Orend claims that some combatants may be held responsible (denying expanded MEC) while still holding that base MEC generally applies. ${ }^{1}$ However, in general it appears base and expanded MEC will be affirmed or denied together. It does not make much sense to blame someone for exercising a moral privilege. However, extreme MEC can be easily separated from base and expanded MEC by supererogatory actions. There may be behavior that is morally allowed and not blameworthy that one could still be praiseworthy for avoiding.

SCO and MEC affect the moral empowerment of combatants in numerous ways. If combatants are to consider the justice of the wars in which they fight, a policy allowing SCO would provide them a way to act upon their beliefs without risking imprisonment. Denying MEC would make room for the possibility that the justice of a state's cause could affect the rights and privileges of a combatant. For instance, a combatant in an unjust military venture might not have the moral privilege to direct deadly force against a just combatant. Affirming MEC may encourage combatants to fight in an unjust war effort by eliminating the possibility of blame. Although the focus of my project is SCO, I will begin by discussing MEC. In many ways, the two topics are inseparable. With the above definitions and a brief introduction in mind, I will turn to what different theorists have to say on the issue, beginning with Walzer.

\footnotetext{
${ }^{1}$ Orend, War, 110.
} 


\section{Walzer}

Although he was not the first to wrestle with these issues, Walzer reignited the debate in contemporary just war theory by penning the phrase "moral equality of soldiers," which was then modified into MEC. ${ }^{2}$ Recall that Walzer claims there is a line between jus ad bellum and jus in bello, and that line separates the responsibilities of the state from those of combatants. Elsewhere, Walzer claims MEC is "a moral condition" which gives soldiers "an equal right to kill." ${ }^{3}$ Also, although Walzer rightfully condemns combatants who violate jus in bello, of those who fight for an unjust side he states, "so long as they fight in accordance with the rules of war, no condemnation is possible." ${ }^{4}$ This initially suggests he supports expanded MEC.

To justify MEC, Walzer writes, "Without the equal right to kill, war as a rule-governed activity would disappear and be replaced by crime and punishment, by evil conspiracies and military law enforcement." ${ }^{5}$ Richard Schoonhoven, expands this argument stating, "If killing even combatants is a criminal act, then what distinguishes it from killing noncombatants? And if nothing does, then what distinguishes war from wholesale slaughter?" ${ }^{6}$ In the previously mentioned overarching explanations for just war theory (restraint, human rights, and prima facie duties), we need to distinguish between war and slaughter, and it is the rules of war that enable this distinction.

\footnotetext{
${ }^{2}$ Walzer, Wars, 34.

${ }^{3}$ Ibid., 41.

${ }^{4}$ Ibid., 128.

${ }^{5}$ Ibid., 41.

${ }^{6}$ Richard Schoonhoven, "Invincible Ignorance, Moral Equality, and Professional Obligation," in Empowering Our Military Conscience Transforming Just War Theory and Military Moral Education, edited by Roger Wertheimer, 107-129, (Famham: Ashgate Publishing Group, 2010), 123.
} 
Walzer offers ignorance, immaturity, and fear as excuses for why some combatants "can hardly be said to make a moral decision at all" when joining the war effort. ${ }^{7}$ Those combatants who are morally excused are also blameless. However, although excuses may remove blame, excuses are not needed if there are no prima facie moral shortcomings. Also, regarding the reasons that political leaders give for war, Walzer writes, "It takes courage to doubt these reasons, or to doubt them in public." ${ }^{8}$ That these doubts would be courageous suggests that they may be praiseworthy. Referencing combatants encountered with the unjust war in Vietnam (and unjust wars in general), Walzer writes, "They act very well if they refuse to fight, and we should honor those-they are likely to be few-who have the self-certainty and courage to stand against their fellows." ${ }^{\prime 9}$ Here Walzer gives clear evidence that he considers it praiseworthy to object to an unjust war. This evidence suggests that Walzer does not support extreme MEC, and may support a moral right to SCO.

As an example of judgments shaped by MEC, Walzer gives the case of General Rommel. Rommel burned an order from Hitler to kill "enemy soldiers encountered behind the German line," and Walzer praises him for this. ${ }^{10}$ Walzer then states, "It would be very odd to praise Rommel for not killing prisoners unless we simultaneously refused to blame him for Hitler's aggressive wars." ${ }^{11}$ However, even Walzer backs away from a wholehearted endorsement of base and expanded MEC saying, that in the case of Rommel "we still have misgivings ... but by

\footnotetext{
${ }^{7}$ Walzer, Wars, 40.

8 Ibid., 39.

9 Ibid., 299.

10 Ibid., 38.

11 Ibid.
} 
and large we don't blame a soldier, even a general who fights for his own government."12

'Misgivings' and 'by and large' suggests Walzer may consider exceptions to base and expanded MEC. Elsewhere, Walzer is "sympathetic" with Eisenhower's decision to not allow a captured German general a courtesy visit. ${ }^{13}$ This suggests that there may even be some blame given to that general. In sum, despite a few caveats it appears that Walzer endorses expanded MEC, but he does not affirm extreme MEC. He also supports a moral right to SCO, but there is no evidence that he supports a moral duty to SCO.

\section{Historical Arguments for SCO or MEC}

Although denying a moral duty to SCO and affirming some form of MEC is the prevailing view defended by Walzer, claiming orthodoxy is a bit of a stretch. Gregory Reichberg and Anthony Coates both consider Walzer's position to be a modern view and contrast it with the "traditional" or "orthodox" view. ${ }^{14}$ I will use two theorists as examples.

Over four hundred years ago, Francisco de Vitoria wrote, "If the war seems patently unjust to the subject, he must not fight, even if he is ordered to do so by the prince." ${ }^{15}$ This implies a moral duty to SCO and denies all forms of MEC at least in cases of patent injustice. Despite requiring this, Vitoria does not require combatants exercise much diligence in determining the justice of a war they are ordered to fight. He writes, "lesser subjects ... are not required to examine the causes of war, but may lawfully go to war trusting the judgment of

\footnotetext{
12 Ibid., 39.

13 Ibid., 37-38.

${ }^{14}$ Coates, “Independent,"176. Reichberg, “Paradigms,” 193-195.

${ }^{15}$ Francisco de Vitoria, On the Law of War, in The Ethics of War: Classic and Contemporary Readings, edited by Gregory Reichberg, Henrik Syse, and Endre Begby, 308-332, (Malden: Blackwell Publishing, 2006), 318. Emphasis removed.
} 
their superiors. ${ }^{16}$ In cases where the justice of war is unclear, Vitoria recommends that combatants follow the "safer course" of obedience. ${ }^{17}$ However, in-line with his first point, he offers the following caveat: "There may nevertheless be arguments and proofs of the injustice of the war so powerful, that even citizens and subjects of the lower class may not use ignorance as an excuse for serving as soldiers." ${ }^{18}$

Vitoria also is credited with applying the concept of invincible ignorance to war:

In the broadest terms, invincible ignorance describes the innocence of people who commit objectively wrong acts without possessing the means to overcome their ignorance. However ignorance is vincible and, hence blameworthy when people have the means to overcome their ignorance but negligently fail to do so. ${ }^{19}$

This seems to counter his previous claim that when the justice of a war is doubtful combatants are not required to investigate the cause. The reasons given by Vitoria for why combatants are not required to investigate are that it is "impossible and inexpedient" for the government to put the debate before the entire public and because "men of lower condition and class cannot prevent war..., since their opinion would not be heard. ${ }^{\prime 20}$ Although in Vitoria's time it may not have been negligent to fail to investigate a war's justice, these reasons may be less applicable today due to contemporary media and political expectations in a democracy. Nonetheless, this is a difficult issue that will be further discussed in later chapters. Despite some confusion as to the efforts required to avoid ignorance, there is no doubt that Vitoria requires combatants to not fight in some wars. Gregory Reichberg credits Vitoria with laying "the groundwork" for

\footnotetext{
${ }^{16}$ Vitoria, Law, 319. Emphasis removed.

17 Ibid., 322. Emphasis removed.

18 Ibid., 319. Emphasis removed.

19 Andrew Sola, "The Enlightened Grunt? Invincible Ignorance in the Just War Tradition," Journal of Military Ethics, 8:1 (2009): 49.

${ }^{20}$ Vitoria, Law, 319.
} 
selective conscientious objection. ${ }^{21}$ However, despite Vitoria clearly recommending objecting in certain cases, some, most notably Paul Christopher, have latched on to invincible ignorance and read Vitoria as supporting MEC and opposing $\mathrm{SCO}^{22}$

Vitoria is not alone: Francisco Suárez echoes him in claiming that "common soldiers" do not need to investigate a war's justice, but rather may go to war when summoned to do so, provided it is not clear to them that the war is unjust. ${ }^{23}$ However, in cases of injustice, he writes, "One is not allowed to proceed to an unjust war," and "to fight in an unjust war is to act unjustly. ${ }^{24}$ Vitoria and Suárez show that there is historical precedence for denying MEC and requiring $\mathrm{SCO}$ in at least some cases. Therefore there is evidence that the prevailing view is not orthodox.

\section{Which Conception of MEC to Reference?}

Having presented Walzer's view and argued against labeling it as orthodox, I will now look at how other contemporary theorists conceive of MEC. Again, although my ultimate focus is SCO, many theorists argue for or against SCO by starting with MEC. I will begin with selecting which conception of MEC to reference. An opponent of MEC, Jeff McMahan describes MEC stating, "Combatants on all sides in a war have the same moral status. They have the same rights, immunities, and liabilities irrespective of whether their war is just." ${ }^{25}$ He adds that MEC is "the idea that no one does wrong or acts impermissibly, merely by fighting in a war that turns out to be unjust. This idea lies at the core of the reigning theory of the just war and also

\footnotetext{
${ }^{21}$ Gregory Reichberg, Henrik Syse, and Endre Begby, The Ethics of War: Classic and Contemporary Readings (Malden: Blackwell Publishing, 2006), 317.

${ }^{22}$ Christopher, Ethics, 89, 160, 163, \& 211.

${ }^{23}$ Francisco Suárez, The Three Theological Virtues: On Charity, in Selections From Three Works of Francisco Suárez, translated by Gwladys L Williams et al., (Oxford: Clarendon Press, 1944), 832.

${ }^{24}$ Suárez, Charity, 834.

${ }^{25}$ McMahan, "Morality," 21.
} 
informs the international law of war." ${ }^{26}$ These quotes show that McMahan targets the expanded version of MEC.

A proponent of MEC, Paul Christopher writes, "Soldiers can never be responsible for the crime of war, qua soldiers." 27 This initially leaves room for objecting to be praiseworthy, but later in his work, Paul Christopher dispels this option. He uses phrases such as "abandonment of the oath of office," "betrayal of the national trust," and "morally reprehensible" to describe a refusal to participate, if ordered, in an unjust war. ${ }^{28}$ Christopher defends this by means of a false dilemma and an exaggeration:

Accepting this position leads to one of two unsatisfactory conclusions. One is that we permit soldiers to leave military service whenever they do not agree with a political decision. The other option is to acknowledge that requiring them to fight a war against their will is immoral, but to make such a political decision legally binding on them anyway. The first alternative would make a mockery of the very notion of having a standing army, and the second one would make a mockery of our legal system." ${ }^{29}$

In addition to the above options, soldiers may remain in service but not participate in a specific war via the mechanism of SCO. Furthermore, Christopher exaggerates the conditions under which a soldier should object. A policy of SCO need not enable soldiers to object to just any political decision, but rather only to an order to fight in a war they believe is unjust. ${ }^{30}$ Although rare and not well supported, the extreme form of MEC is held by some.

\footnotetext{
${ }^{26}$ McMahan, Killing, 3. The language "turns out to be unjust" is unfortunate, because a combatant should be judged based on the information available at the time not hindsight. I would prefer it if McMahan had stated "a war that appears unjust." A combatant who fights a just war that appeared unjust should not be exonerated any more than a combatant who fights an unjust war that appeared just should be blamed.

${ }^{27}$ Christopher, Ethics, 89. Christopher makes no specific mentions of rights and privileges, but he presents jus in bello as applying equally regardless of the justice of one's side (Ethics, 90).

28 Ibid., 145 \& 213.

${ }^{29}$ Ibid., 212.

${ }^{30}$ In my final chapter, I will discuss how stringently combatants will need to demonstrate their beliefs.
} 
Based on the rarity of support for extreme MEC, the fact that Walzer endorses expanded MEC, and the fact that McMahan targets expanded MEC, from here on when I reference MEC, I will be referencing the expanded version unless otherwise stated. I do not intend to argue with Walzer or others who support expanded MEC, as ultimately my method will bypass their discussion. However, I do need to demonstrate that one method to argue for SCO is by first arguing against MEC, and I need to clarify what conception of MEC that entails. With this in mind, I will turn to arguments for SCO, commencing with arguments for SCO that begin by arguing against expanded MEC.

\section{Arguments for SCO}

To help understand some of the arguments for SCO, I have categorized them into three general types: top-down, bottom-up, and enabling. Top-down arguments are those that argue from state rights. This will be the crux of my project, and I will save discussion of it until later chapters. Bottom-up arguments are those that argue from individual rights. Further divided, there are four general types of bottom-up arguments. Two argue for SCO, starting with an aspect of MEC, and two argue for SCO directly. The first argument is that combatants have a duty to avoid killing non-combatants as an aggressor. The second is that combatants have a duty to avoid killing combatants as an aggressor. The third bottom-up argument argues directly for a moral duty to SCO, while the fourth argues directly for a moral right to SCO. I will give an example of each type. There are also enabling arguments which argue for a legal right to SCO based on a presumed moral duty or morally supererogatory action. Enabling arguments often rely on either top-down or bottom-up arguments. The idea is that enabling arguments focus only on legal policies, and consider legal policies as an enabler of a morally required or 
praiseworthy action. Although in general I support these arguments for SCO, my purpose is not to assess the arguments, but rather simply to survey the types of arguments that are currently in use in support of SCO.

\section{Combatants Have a Duty to Avoid Killing Non-combatants as an Aggressor}

One way to derive the principle that a combatant has a duty to avoid killing non-

combatants as an aggressor (and thus a duty to avoid participating in an unjust war) is a more stringent view of what is required by proportionality as a part of the Doctrine of Double Effect (DDE). Again referencing Sidgwick, Walzer states, "We are to weigh 'the mischief done'...against the contribution that mischief makes to the end of victory." ${ }^{31}$ It is worth noting that Walzer uses the same version of proportionality for both combatants and non-combatants (as a part of DDE). ${ }^{32}$ Walzer critiques his own principle noting, "The argument as stated, however, sets the interests of individuals and of mankind at a lesser value than the victory that is being sought." ${ }^{33}$ He adds, "Proportionality turns out to be a hard criterion to apply, for there is no ready way to establish an independent or stable view of the values against which the destruction of war is to be measured." ${ }^{34}$ Although Walzer claims that "the rules of war are grounded in a theory of rights," when calculating proportionality he is balancing rights against victory even if that victory does not contribute to upholding rights. ${ }^{35}$

\footnotetext{
${ }^{31}$ Walzer, Wars, 129.

32 Ibid., 129 \& 153. We will shortly see that other theorists use different conceptions of proportionality for combatants and non-combatants, and these different conceptions have strong implications.

${ }^{33}$ Ibid., 129.

34 Ibid.

${ }^{35}$ Ibid., 137.
} 
Other theorists do consider rights when calculating non-combatant proportionality. In wrestling with questions of proportionality in regards to DDE (and thus in regards to noncombatants), Brian Orend answers:

"The only justification sufficient, in my mind, for the collateral civilian casualties would be that the target is materially connected to victory in an otherwise just war....Only a country fighting a just war can fulfill the proportionality requirement in the DDE. Thus, an aggressor nation fighting an unjust war, for that very reason, also violates the rules of right conduct." ${ }^{\prime 36}$

Although Orend refers to "an aggressor nation," I think his intent is for that statement to also apply to the combatants of an aggressor nation. Left unmentioned in the above quote, but present throughout the work, is the reason why only a state fighting a just war can fulfill proportionality: a just war is one that upholds human rights.

Orend explains this stating, "The main purpose of the state, in our era, is to do its part in realizing the human rights of its people." ${ }^{37}$ Of course to do this, states must have rights. ${ }^{38}$ As previously sketched, a just war protects those state rights and the related individual rights, but in doing so, some individuals rights will be infringed. However, an unjust war violates state rights and, rather than infringe individual rights for the purpose of protecting other rights, violates individual rights for no good reason.

Jeff McMahan also doubts that civilian deaths in pursuit of an unjust cause can be proportional:

In order for the killing of innocent civilians not to be excessive in relation to the expected military advantage of an attack, military advantage must be good. Yet military advantage for those who are in the wrong and are fighting for the defeat of a just cause is, except perhaps in highly anomalous conditions, bad impartially considered. It makes

\footnotetext{
${ }^{36}$ Orend, War, 118.

${ }^{37}$ Ibid., 33.

38 Ibid., 34.
} 
no sense to say that the killing of a certain number of innocent people as a side effect of an act of war is outweighed by the contribution that the act makes to the achievement of goals that are unjust. ${ }^{39}$

From either Orend's or McMahan's conception of proportionality in relation to DDE, a combatant's duties to avoid must change from those Walzer espouses. We must add a combatant duty to avoid killing non-combatants as an aggressor. Since it is nearly impossible for a war to be fought without endangering non-combatants, this now implies that a combatant has a duty to avoid participating in an aggressive war, except perhaps in anomalous wars that do not endanger non-combatants. If a combatant has a duty to avoid participating in an unjust war, then this denies MEC and affirms a moral duty of SCO.

\section{Combatants Have a Duty to Avoid Killing Combatants as an Aggressor}

In addition to a restriction on killing non-combatants as an aggressor, we could also consider whether such a restriction should apply to killing combatants as well. Introducing his jus in bello chapter, Orend writes, "We'll see that we literally cannot make sense of some jus in bello rules-notably, proportionality-[...]without considering the just cause of the war to begin with." 40 However, in discussing proportionality towards combatants, Orend does not specifically make such a revolutionary argument as he does for non-combatants. He writes, "Make sure, the rule commands, that the destruction needed to fulfill the goal is proportional to the good of achieving it." ${ }^{41}$ He labels Saddam Hussein's use of oil spills and fires during the First Gulf War as disproportionate, which implies that those specific acts were disproportionate, not just any acts committed by the Iraqi Army (which as an aggressive invader of Kuwait, clearly

\footnotetext{
${ }^{39}$ McMahan, Killing, 30.

${ }^{40}$ Orend, War, 105-106.

${ }^{41}$ Ibid., 119.
} 
lacked a just cause). ${ }^{42}$ Nowhere does he mention a just war affecting combatant proportionality as he does regarding non-combatants. From this it is unclear that Orend intends to imply that killing combatants as an aggressor unjustly violates proportionality.

This leaves a bit of a mystery as to why Orend does not claim that an unjust side cannot fulfill combatant proportionality as is the case with DDE proportionality. Perhaps in his quote introducing his jus in bello chapter, he meant to reference only DDE proportionality. However, even if that is the case, it does not explain why he revises the prevailing view of proportionality regarding non-combatants but not regarding combatants.

One possible explanation is that at times Orend is descriptively stating what the prevailing view of just war theory is, and at other times he is normatively revising just war theory as he thinks it should be. In this case he moved between the two approaches. Another explanation is that by labeling all acts of war by an aggressive army as disproportionate (in the revised sense), there may be no incentive for unjust combatants to not engage in disproportionate acts (in the prevailing sense). Although there is no justification for killing 1,000 just combatants in pursuit of an unjust cause, it is much worse to kill 100,000 just combatants in pursuit of an unjust cause. However, Orend has already labeled all attacks by unjust combatants that threaten non-combatants as disproportionate, so with similar logic, an unjust combatant may have no incentive to care about non-combatant proportionality (in the prevailing sense) as a part of the DDE. This possible explanation fails to satisfy, but it does introduce the issue of incentives for unjust combatants to restrain violence which will be further discussed in a later chapter.

${ }^{42}$ lbid. 
Instead of referencing proportionality, Jeff McMahan invokes discrimination to support changing duties towards just combatants. Recall that Walzer discriminates combatants from non-combatants by the fact that combatants "bear arms" and "pose a danger to other people" and thus can be attacked. ${ }^{43}$ McMahan summarizes this stating, "according to mainstream just war theory[...], the criterion of liability to attack in war is simply posing a threat." ${ }^{44}$ For McMahan, however, the traditional criterion comes apart as it is not just about posing a threat of harm. Instead McMahan proposes that "the criterion of liability to attack in war is moral responsibility for an objectively unjustified threat of harm." ${ }^{45}$ Just combatants are a justified threat. According to this, then, combatants should avoid killing just combatants as an aggressor, as to do otherwise would violate the jus in bello requirement of discrimination. McMahan argues, "Unjust combatants can seldom satisfy the jus in bello requirement of discrimination, since just combatants seldom make themselves liable to attack and thus are in general illegitimate targets. ${ }^{\prime 46}$

This new standard excludes from the group of legitimate targets most just combatants, but does it also exclude unjust combatants who cannot be morally responsible? If this is the case, does it ultimately exclude most combatants and thus become virtually useless? I won't go into details (McMahan uses two chapters to examine this issue), but he ultimately concludes that although there are many unjust combatants who might have partial or complete excuses such as epistemic limitations or duress, "there is a basis for liability in the case of virtually all

\footnotetext{
${ }^{43}$ Walzer, Wars, 145.

${ }^{44}$ McMahan, Killing, 11.

45 Ibid., 35.

${ }^{46}$ Ibid., 18. In Chapter Four, I will mention an exception to the lack of liability to attack by an unjust combatant
} 
unjust combatants.." ${ }^{\prime 77}$ In other words, most unjust combatants are morally responsible. McMahan would include in this group all but the youngest of child soldiers. However he does say that although they are liable to attack, when feasible, just combatants should exercise restraint against child soldiers due to their strong excuses and the fact that they are children. ${ }^{48}$ One difficulty with this approach to denying MEC is if an unjust combatant is already morally wrong for participating, what can be done to encourage restraint? In the language of discrimination, if unjust combatants have already failed to discriminate by fighting combatants who are not liable to attack, they may not bother to further discriminate by refraining from attacking non-combatants. By McMahan's standard just combatants and non-combatants deserve equal protection, in that neither should be attacked. As previously mentioned, this issue of incentivizing restraint by unjust combatants will be discussed in a later chapter.

Another issue with this standard of liability is that it implies that unjust combatants would be permitted to fight other unjust combatants. For example, consider two aggressive states fighting each other to carve up a third victim state. To alleviate this concern, McMahan clarifies that although unjust combatants would be liable to attack in the simple sense, it does not mean that other unjust combatants would be justified in doing so. ${ }^{49}$ Just as criminals are liable to punishment from the criminal justice system but not from vigilantes, unjust combatants are only liable to attack from just combatants. ${ }^{50}$ As no one (not even an unjust combatant) is generally liable to attack by an unjust combatant, this now implies that a combatant has a duty to avoid participating in an aggressive war.

\footnotetext{
${ }^{47}$ McMahan, Killing, 115-121 \& 183.

48 Ibid., 198-202.

49 lbid., $17 \& 18$.

${ }^{50}$ lbid., 18.
} 
This may seem unfair to make unjust combatants surrender their apparent right to selfdefense when attacked by other unjust combatants. Are we really to say unjust combatants cannot fight back when attacked by other unjust combatants? Although this may counter intuitions about self-defense, we should bear in mind that unjust combatants are not acting out of self-defense but rather are acting out of aggression. They should not be there in the first place. Descriptively, this prohibition is not likely to affect actions since as aggressors against a third party; the unjust combatants have already shown that they are willing to fight those not liable to attack. There is no reason to think that they would feel bound to not fight other unjust combatants.

I should clarify how the last two arguments (a duty to avoid killing non-combatants as an aggressor and a duty to avoid killing combatants as an aggressor) argue for SCO. If combatants have a duty to avoid participating in an aggressive war then combatants do not have equal rights and can be blamed for participating in an unjust war. In order to fulfill their duty and avoid blame, a combatant must not fight in an unjust war, even if ordered. In addition to objecting, there are of course other ways to not participate (feigning participation, desertion, surrender, self-injury, suicide), but it is obvious that SCO is a more practical way to fulfill a duty to not participate in an unjust war. Although some may at first consider objecting to be supererogatory, if avoiding participating in an unjust war is a duty, then by definition, there can be nothing supererogatory about it.

\section{A Direct Argument for a Moral Duty to SCO}

Jessica Wolfendale presents a bottom-up argument that argues directly for SCO. She argues that military members ordered to fight in an unjust war have a duty to refuse based on 
professional ideals. ${ }^{51}$ She distinguishes this type of objection from conscientious objection, as she claims that conscientious objection is motivated by "personal values" but refusal on professional grounds is based on "professional values". ${ }^{52}$ I do not agree with this distinction, but it is not necessary to accept it in order to accept the rest of her argument. Some objections to a particular war might be personal; for example, immigrants or the offspring of immigrants might refuse to fight against their ancestral state regardless of justice. However, there is no reason that SCO can't be for professional reasons.

Modern militaries claim to be a profession, and share criteria with professions like medicine and law such as "a monopoly on the provision of its services," and "specialized and high-level training." ${ }^{53}$ However, professions are also thought to serve an "important moral good" or an "important human need." ${ }^{54}$ While defending a legitimate state can meet these criteria, if a military carries out government policies that are not required for defense, then it jeopardizes the military's claim to professional status. This would be comparable to a doctor who uses her medical skills to aid in torture. Such doctors "have betrayed the ideals of their profession and the public welfare that their profession exists to protect." 55

Wolfendale argues that the moral constraints which govern the military profession include all of just war theory. If the military is a profession, and professions are expected to uphold professional moral constraints, then the military's professional jurisdiction should include not only jus in bello guidance but also jus ad bellum guidance. She writes:

\footnotetext{
${ }^{51}$ Jessica Wolfendale, "Professional Integrity" and Disobedience in the Military," Journal of Military Ethics, 8:2 (2009): 127-140.

${ }^{52}$ Wolfendale, "Professional Integrity," 132.

53 lbid., $127 \& 129$.

54 Ibid., 129.

55 lbid., 133.
} 
If military personnel are ordered to participate in a military operation that they have good reason to believe violates the military's moral and/or legal commitments, they not only have permission to refuse to participate in such actions; they have a positive moral duty to refuse to participate, on the grounds that participation would violate the very moral values that the military profession is supposed to be committed to. ${ }^{56}$

A way to avoid her conclusion is to deny professional status to the military. Wolfendale does not directly address this option, but she hints at a reductio ad absurdum by claiming that "without professional status the military would be morally no better than a mercenary army." ${ }^{57}$ She does not discuss the statement further, but assumes the reader views this as both a correct comparison and an unacceptable option. Furthermore, since the military itself claims to be a profession, it is assumed that the military would consider surrendering professional status to be unacceptable. $^{58}$

Of all the arguments for SCO I present, Wolfendale's is the most difficult to categorize. She works within the virtue ethics tradition and thus rights are not her starting point. ${ }^{59}$ However, an emphasis on individual human flourishing focuses more on the individual than on the state. It is for this reason that I categorize her arguments as bottom-up.

\section{SCO as a Moral Right}

I have not encountered anyone who argues for SCO exclusively as a moral right.

However, in addition to Walzer, I will mention one who hints at the possibility. James Childress writes, "In all political orders the subject has a moral right/duty-although not a legal rightnot to fight if the war is manifestly unjust." ${ }^{60}$ He does not specify why this right/duty exists, but it is implied (based on the essay's discussion of prima facie duties) that a moral right/duty of

\footnotetext{
${ }^{56}$ Ibid., 134.

57 Ibid., 127.

58 Ibid.

59 Jessica Wolfendale, Torture and the Military Profession (New York: Palgrave, 2007), 28-46.

${ }^{60}$ Childress, "Just-War," 436.
} 
SCO exists to enable a combatant to uphold their moral duty to not injure or kill except when that duty is overridden by a higher obligation. An unjust war does not override the prima facie duty to not injure or kill. This argument is based on not violating individual rights. It is not tied specifically to the rights of combatants or non-combatants, but can easily be specified for either, simply by inserting 'directly' or 'indirectly' in front of 'injure or kill.' The language of prima facie duties suggests that Childress considers SCO to be more of a moral duty than a moral right, but one reason to argue for a right, but not a duty, would be if objecting was supererogatory, but not obligatory. Reasons to consider SCO as supererogatory are the social pressures and legal punishments against objecting.

\section{Enabling Arguments for a Legal Right to SCO}

There are some arguments that are neither top-down or bottom-up arguments. Rather they are arguments for a legal right to SCO and they are compatible with, and often rely on, either top-down or bottom-up arguments. Examples of these enabling arguments are given by those who would argue for a legal right to SCO based on a presumed moral duty or morally supererogatory action. The legal right is needed to enable a combatant to act according to their conscience. The idea is that these cases focus only on legal policies, and consider legal policies as an enabler of a morally required or praiseworthy action.

After giving his arguments for why combatants should not fight in unjust wars, Jeff McMahan also gives an argument for why combatants should have a legal right to SCO. Currently states punish combatants who refuse to fight when ordered. This places combatants in a dilemma. McMahan writes, "If they obey the command to fight, they will be guilty of serious wrongdoing. If they conscientiously refuse to fight, the society that has trained and 
encouraged them to exercise their moral autonomy will punish them for disobedience. Either way, the government and the society unfairly impose on them the costs of the government's wrongdoing." ${ }^{61}$ The way out of the dilemma is to deny the first horn by affirming MEC, or to deny the second by allowing SCO. As McMahan denies MEC, we are left with affirming a legal right to SCO.

James Childress argues for a legal right to SCO based on "principles of respect for persons and fairness" since a legal right to UCO is already recognized in the United States. ${ }^{62}$ He considers the issue and ultimately concludes that there is not a "sharp distinction" between the two types of objectors, therefore they should be treated similarly. ${ }^{63}$ However, if the legal right to UCO is viewed merely as a privilege, which Childress notes the Supreme Court "has frequently observed," then arguments will also be needed to defend that privilege. ${ }^{64}$ Otherwise, an argument for fairness can be met by denying the privilege to both types of objectors. Like the other enabling arguments, this is dependent on an assumed moral duty or at least a morally praiseworthy action that would cause combatants to need such a right.

\section{Conclusion}

The purpose of this chapter was to introduce the topics of SCO and MEC, and give a general idea of the type of arguments for SCO and against MEC. Although in general I support these arguments for SCO, my purpose was not to assess the arguments, but rather survey the types of arguments that are currently in use. This lays the groundwork for presenting my top-

\footnotetext{
${ }^{61}$ McMahan, Killing, 97.

62 James Childress, Moral Responsibility in Conflict (Baton Rouge: Louisiana State University Press, 1982 ), 205 \& 213.

63 Ibid., 205.

64 Ibid., 193.
} 
down argument for SCO in later chapters. As in any debate, there are, of course, arguments against my position. I will discuss some of these in my final chapter. 


\section{Chapter Three: Henry Shue's “Institutional Turn in Thinking about Human Rights" $^{1}$}

\section{Henry Shue's Basic Rights}

Charles Beitz and Robert Goodin state that Henry Shue's Basic Rights "advances positions which, although heretical when the book was first published, have since become close to philosophical orthodoxy." ${ }^{2}$ Shue revolutionizes the landscape of rights and duties by dissolving the supposed dichotomy of positive and negative rights/duties. With the dichotomy left in place there is a danger of many rights becoming mere manifesto rights. For example, a strictly negative interpretation of a right against assault would only require negative duties to not assault others. Thus a bystander could comply with their duty to not assault while standing by and watching another assault a victim. Instead, Shue believes we need to ensure rights are "socially guaranteed against standard threats." ${ }^{3}$ In the case of a right against assault, Shue posits that in addition to uncontroversial duties to avoid assaulting others, people also have duties to protect others from assault and duties to aid the victims of assault. ${ }^{4}$

This raises questions: what are social guarantees and what are standard threats? Social guarantees are "arrangements so that one will still be able to enjoy the substance of the rights, even if-actually, especially if-it is not in one's own power to arrange on one's own to enjoy the substance of the right.." ${ }^{5}$ The idea is that people need to take positive action to ensure that rights are honored, not just avoid directly violating rights.

\footnotetext{
${ }^{1}$ Shue, "Afterword," 166.

${ }^{2}$ Charles Beitz and Robert Goodin, "Introduction: Basic Rights and Beyond," in Global Basic Rights, edited by Charles Beitz and Robert Goodin, (Oxford: Oxford University Press, 2009), 2.

${ }^{3}$ Shue, Basic Rights, 13.

${ }^{4}$ Ibid., 52.

${ }^{5}$ Shue, Basic Rights, 16.
} 
However, there are limits as to what actions are required. Shue states, "People are neither entitled to social guarantees against every conceivable threat, nor entitled to guarantees against ineradicable threats like eventual serious illness, accident, or death." ${ }^{6}$ Instead we only need to provide guarantees against standard threats such as those that "could ordinarily be expected to prevent, or hinder to a major degree, the enjoyment of the initial right assumed." ${ }^{7}$ It is one thing to protect a right to life from assault, but another to protect it from the inevitability of old age. For example, neither Shue nor I would suggest that we have an obligation to continually push the limit of the average human life expectancy. ${ }^{8}$ Shue is also concerned with rights evolving into something unreasonably robust. To address this concern, he states, "I am not suggesting the absurd standard that a right has been fulfilled only if it is impossible for anyone to be deprived of it or only if no one is ever deprived of it. The standard can only be some reasonable level of guarantee." ${ }^{9}$

As his title suggests, Shue is focused on basic rights which he believes "are everyone's minimum reasonable demands upon the rest of humanity." ${ }^{10}$ In explaining the notion of basic rights, he states, "The substance of a basic right is something the deprivation of which is one standard threat to rights generally. The fulfillment of a basic right is a successful defense against a standard threat to rights generally. This is precisely why basic rights are basic." ${ }^{11}$ What he means by this is that when someone is lacking a basic right, they are more vulnerable to other rights violations. Conversely, when basic rights are protected people are less

${ }^{6}$ Ibid., 32.

${ }^{7}$ Ibid.

${ }^{8}$ Ibid., 23. Of course upholding basic rights should change the average life expectancy, as many who currently die from the lack of basic subsistence needs will survive.

${ }^{9}$ Ibid., 17.

10 Ibid., 19.

${ }^{11}$ Ibid., 34. 
vulnerable to other rights violations. I would also like to emphasize that Shue is discussing the substance of rights. He explains, "The substance of a right is whatever the right is a right to. A right is not to enjoy a right - it is a right to enjoy something else, like food or liberty."12 This demonstrates that what people care about is the enjoyment of what a right entails, not the bare right itself. It is not just a matter of declaring basic rights. It is not just a matter of avoiding violating basic rights. If any rights are to be enjoyed, duties to protect are required to guarantee the substance of basic rights.

For example, if people are to have a right to assemble, they must be protected from being beaten for assembling and from being fired by their employer for assembling. Otherwise, they do not really have a right to assemble except perhaps on paper. ${ }^{13}$ Shue borrows an example from Thomas Pogge, regarding live-in maids. ${ }^{14}$ Domestic-servants are often abused and mistreated by their employers, a violation of a right to security. Without a right to subsistence, however, they are vulnerable to the dilemma of either continuing to endure abuse or losing their job and perhaps starving. A basic right to subsistence would make it much more difficult for their employers to violate their right to security.

Shue begins with the right to physical security which he believes is relatively uncontroversial. ${ }^{15}$ However, as a justification he argues that without a right to physical security it would be very easy to deprive people of any other right. He writes, "If any right is to be exercised except at great physical risk, physical security must be protected." ${ }^{16}$ From, there

\footnotetext{
${ }^{12}$ Ibid., 15.

${ }^{13}$ Ibid., 26.

${ }^{14}$ Ibid., 162-163.

${ }^{15}$ Ibid., 20 \& 22.

${ }^{16}$ Ibid., 21.
} 
Shue argues for subsistence as a basic right based on the fact that both security and subsistence "are equally essential to providing for the actual exercise of any other rights." ${ }^{17}$ He clarifies, "Deficiencies in the means of subsistence can be just as fatal, incapacitating, or painful as violations of physical security." ${ }^{18}$ Although Shue focuses his discussion on subsistence rights, and to a lesser extent security rights, he expands beyond those two, saying[:] "Freedom of physical movement, as well as the liberty of economic and political participation, are basic rights, because enjoyment of them is an integral part of the enjoyment of anything as a right."19 I will not elaborate on these last items as my focus is on security rights.

In order to uphold basic rights, Shue proposes a tripartite division of duties. For any basic right, Shue claims that there are duties to avoid rights violations, duties to protect from rights violations, and duties to aid those whose rights have been violated. ${ }^{20}$ I will give an example to help explain what Shue means. In the case of physical security, a duty to avoid simply rules out assault, murder, etc. A duty to protect would involve "police forces; criminal courts; penitentiaries; schools for training police, lawyers, and guards; and taxes to support an enormous system for the prevention, detection, and punishment of violations of personal security. ${ }^{\prime 21}$ The purpose of duties to protect is to prevent assaults and other violent crimes from occurring. Aid is "positive action by society to restore [rights] when avoidance and protection both fail."22 An example of this is after someone has been a victim of assault, aid to

\footnotetext{
${ }^{17}$ Ibid., 26.

18 Ibid., 24.

${ }^{19}$ Ibid., 65 \& 81-82.

${ }^{20}$ Ibid., 52.

${ }^{21}$ Ibid., 37-38.

22 Ibid., 53.
} 
physical security would involve medical professionals helping the victim recover physically and perhaps also psychologists or counselors helping the victim recover emotionally.

Shue is specific about what duties to protect and aid entail. For example, there are two types of duties to protect. There are not just "the kinds of acute threats of deprivation that police can prevent, but [also] the kinds of chronic threats that require imaginative legislation and, sometimes long-term planning." ${ }^{23}$ Shue also expands the types of aid based on either special relationships, or how it is that victim came to be in need of aid. He summarizes his tripartite framework:

The fulfillment of a basic right [...] involves at least the following kinds of duties:

I. To avoid depriving.

II. To protect from deprivation

1. By enforcing duty (I) and

2. By designing institutions that avoid the creation of strong incentives to violate duty (I).

III. To aid the deprived

1. Who are one's special responsibility,

2. Who are victims of social failures in the performance of duties (I), (II-1), (II-2) and

3. Who are victims of natural disasters. ${ }^{24}$

I will not focus much on duties to aid, but duties to protect will figure heavily in my project. To elaborate on the two of the types of duties to protect quoted above: Shue gives an example regarding subsistence rights. He demonstrates the difference between duties to protect against "acute threats" such as destroying a farmer's crops and against "chronic threats" such as the one Shue describes in his hypothetical flower contract scenario given below. ${ }^{25}$

\footnotetext{
23 Ibid., 62.

24 Ibid., 60.

${ }^{25}$ Ibid., 62.
} 
In this scenario the inhabitants of a small village eat black beans as their primary source of protein. Most grow some of what they need, but supplement their diet through purchase. A large amount of the beans purchased come from a specific peasant's farm. The owner of that farm accepts a contract that will guarantee him payments for switching to growing flowers for export. The price of beans rises due to decreased supply, ultimately resulting in malnutrition. ${ }^{26}$ Shue describes the malnutrition as a "social disaster" which "was the product of specific human decisions permitted by the presence of specific social institutions and the absence of others, in the context of the natural circumstances, especially the scarcity of land upon which to grow food." ${ }^{27}$ Neither the farmer nor the contract agency "were malicious or intended to do anything worse than single-mindedly pursue their own respective interests. ${ }^{28}$ Thus, to prevent similar "social disasters," for situations "in which individual self-restraint would be too much to ask, the duty to protect (II-2) includes the design of laws and institutions that avoid reliance upon unreasonable levels of individual self-control. ${ }^{29}$ As an example of suitable arrangements, Shue submits that the government could make contracts that switch land use from food production illegal or tax such contracts "in order to compensate those who would otherwise be predictably damaged." ${ }^{30}$

Before addressing II-2 duties to protect, I would like to further consider the issue of selfcontrol mentioned above. Does the peasant farmer violate a duty by accepting the contract and is it fair to require this duty? Shue's clarification of duties to avoid in regards to

\footnotetext{
${ }^{26}$ Ibid., 41-45.

${ }^{27}$ Ibid., 44.

${ }^{28}$ Ibid., 42.

${ }^{29}$ Ibid., 44 \& 59.

${ }^{30}$ Ibid., 44.
} 
subsistence- "Duties not to eliminate a person's only means of subsistence"-implies that the farmer had a duty to not accept the contract. ${ }^{31}$ By accepting the contract, even if unmaliciously and unknowingly, he did eliminate many others' last means of subsistence. However, elsewhere Shue suggests that such a duty may be unfair in that it would require "super human qualities" or that the farmer would have to be a "saint" to not accept the contract. $^{32}$ To reconcile these two points, my interpretation is that the farmer, due to his own economic insecurity or perhaps a lack of foresight, violated a duty, but one for which he can be excused either due to duress or epistemic limitations. Shue views the onerousness of the duty not as a reason to not require the duty to avoid, but rather as a reason to make the duty to avoid easier to comply with.

Shue uses the less controversial security rights, to build his case for subsistence rights. I do not rely on subsistence rights for my project, so although I will sometimes discuss them as many of Shue's examples are related to subsistence rights. Ultimately if the reader is unconvinced of a basic right to subsistence it does not derail my project.

\section{How I Interpret Shue}

Shue specifically states that there is a Type II-2 duty to "avoid the creation of strong incentives to violate duty." ${ }^{33}$ However, in the hypothetical flower contract scenario given above, he makes suggestions that go beyond that requirement. He suggests actions (taxing land use contracts or making them illegal) that instead create a strong incentive to avoid violating duty. What exactly does Shue intend by Type II-2 duties? What is meant by a strong

\footnotetext{
${ }^{31}$ Ibid., 53.

32 Ibid., 59 \& 60 .

${ }^{33}$ Ibid., 60.
} 
incentive to violate duty? Imagine a state that punishes murder with only a few hours of community service. Does such a state provide a strong incentive to commit murder? Strictly speaking, no, the state does not provide an incentive to commit murder (murderers have other motivations), but such a state does not provide the disincentive to avoid murder that most states do and should provide. If there is to be any sort of right to security, a state has a duty to provide a more stringent punishment. Or, consider if a government ignores the bribery of government officials. This does not provide an incentive to bribe officials, but it certainly fails to provide a disincentive to bribery.

Simply avoiding strong incentives to violate duty may not be enough to protect rights. While the preceding paragraph gives a good reason to expand the requirement, what is Shue's intent? Is it too charitable to claim that Shue holds that institutions must do more? Let's return to the flower contract. The peasant farmer who switches to flower production is not provided a strong incentive by the government, but rather by the free trade of interested companies and the world order. Although the peasant's government may not have directly caused the problem, it can curb it. However, making such contracts illegal is not a case of avoiding strong incentives to violate duty, but rather, a case of creating a strong incentive to avoid violating duty. A compensatory tax could also fit under such a requirement in that by making it easier to not violate a duty, the tax provides an incentive to not violate a duty.

Shue's response to his own hypothetical example suggests he supports a more positive interpretation of Type II-2 duties. Sixteen years later, in the afterword of his second edition, Shue explicitly states his beliefs are consistent with a more positive approach. He writes, "I gave the creation of better institutions designed to ensure that rights are respected in the first 
place less attention than I now believe it deserves. Worse, I conceived of duty II-2 much too negatively and much too narrowly." ${ }^{34}$ This however leaves us with the question of how exactly to expand more positively and broadly the duty? One method that initially appears promising is to rely on the rhetorical device of a chiasmus; it is not enough to "avoid the creation of strong incentives to violate duty," but we must also create strong incentives to avoid the violation of duty. $^{35}$

This initially appears to fit with the idea of creating strict punishments against murder, or making contracts similar to the flower contract illegal. However, strictly speaking, punishments for murderers are a disincentive to commit murder, not an incentive to avoid murder. Thus instead of just the two requirements, we would need to have four to account for disincentives as well. For example, four possible requirements of institutional design might look like this:

$1 A^{*} \quad$ Avoid creating incentives to violate duty (avoid encouraging the wrong thing). 1B Avoid creating disincentives to not violate duty (avoid discouraging not doing the wrong thing).

$2 A^{* *} \quad$ Create incentives to avoid violating duty (encourage not doing the wrong thing).

2B Create disincentives to violate duty (discourage doing the wrong thing). ${ }^{36}$

* Similar to Shue's original language

** Similar to my first expansion

While these four more completely cover the conceptual space, they create a few problems. Do we have to remove current incentives or disincentives or just avoid creating new ones? If we do remove current incentives and disincentives, do we have to remove them all, or just reduce the overall number? What is the stopping point? It seems that the existence of

\footnotetext{
${ }^{34}$ Shue, "Afterword," 159.

${ }^{35}$ Shue, Basic Rights, 60.

${ }^{36}$ I have slightly modified the verbiage to make them more succinct.
} 
some undesired incentives or disincentives is unavoidable, so removing all would be an impossible task. When looking at a requirement to create incentives or disincentives (2A and 2B), we also have to ask if we are just required to create some, or do we have to continue to create them until we reach a certain point? These questions and ballooning complexity suggest another solution is more desirable.

Fortunately, Shue also gives us a little more to work with. Later in the revised afterword, he adds, "Duties to protect [should be], broadly interpreted to include the design and maintenance of institutions that make it as easy as possible for people to honor their duties not to deprive others of the enjoyment of their rights or, put differently, as hard as possible to commit, and to get away with, deprivations." ${ }^{37}$ It is important to emphasize that Shue is discussing "duties to protect" and that the aim is limiting deprivation. While the previous quote avoids having to list four separate requirements under Type II-2 duties, it brings with it its own problems. Due to this, I will refer to the previous quote as Shue's "Troubling Quote."

Does Shue really intend for minimal ease and maximal difficulty, as I have emphasized in this troubling quote? Elsewhere, in the afterword, Shue writes, "These positive duties to protect are duties to conceive and nurture institutions that, taking people as they are, and as they can be brought to be, make at least the basic rights of all reasonably secure." ${ }^{38}$ Shue's own use of "reasonably secure" suggests he does not intend to maximize the security of rights. Also, he writes that securing rights "need not involve endless duties," which would also seem to deny a requirement of maximization. ${ }^{39}$ Again, it is important to emphasize that in this quote as well,

\footnotetext{
${ }^{37}$ Shue, "Afterword," 173 (emphasis added).

38 Ibid., 173-174 (emphasis added).

39 Ibid., 173.
} 
Shue is discussing "positive duties to protect," not duties to aid. Furthermore, guarding against maximization is not just present in the afterword. As previously noted, from his first chapter, Shue writes, "I am not suggesting the absurd standard that a right has been fulfilled only if it is impossible for anyone to be deprived of it or only if no one is ever deprived of it. The standard can only be some reasonable level of guarantee." 40

If he is not aimed at maximization, why then does Shue previously say "as easy as possible" and "as hard as possible?" I interpret this as rhetorical flourish aimed at painting a picture of a less negative and narrow view of duties to protect, rather than setting a nearly impossibly hard standard for the desired level of protection. I think this quote is intended to "broadly" interpret duties to protect. This is contrasted with a narrow interpretation such as, "avoid the creation of strong incentives to violate duty." Shue is neither suggesting we maximize the security of rights nor is he suggesting we merely take a few actions that avoid/create the proper incentives/disincentives. Instead, he wants us to think beyond narrowly avoiding incentives to violate and focus on the bottom line of how to make rights properly secure. This can be accomplished by various combinations of avoiding and creating both incentives and disincentives.

I will attempt a different interpretation (modification) of the "Troubling Quote." I believe that Shue meant to say something like, "Duties to protect [should be], broadly interpreted to include the design and maintenance of institutions that make it as easy as [reasonably] possible for people to honor their duties not to deprive others of the enjoyment of their rights or, put differently, as hard as [reasonably] possible to commit, and to get away with

\footnotetext{
${ }^{40}$ Shue, Basic Rights, 17 . See also, page 32.
} 
deprivations." ${ }^{41}$ This modification hopefully allows me to shift focus from maximization to "reasonably secure," while retaining the broadening of duties to protect.

First and foremost, this reading is supported by Shue's use of "reasonably secure" in the afterword, and "reasonable" in the first chapter. ${ }^{42}$ This reading makes more sense than ascribing to him an apparent contradiction with his use of "as easy as possible" and "as hard as possible" on the previous page. ${ }^{43}$ Philosophically this reading makes more sense as maximizing the security of rights seems to be a nearly impossible task. I will further analyze the difficulty of maximizing rights later in this chapter.

I propose an alternative to focus on requirements such as, "avoid the creation of strong incentives to violate duty" or, my own "create strong incentives to avoid the violation of duty." ${ }^{44}$ In determining the requirements of institutional design, we should ask: Does the institutional arrangement (proposed or existing) contribute to making it as easy as reasonably possible to honor duties to avoid or as hard as reasonably possible to violate duties to avoid? If yes, include it. If not, reject or modify it. I would restate Type II-2 duties as ones that protect from deprivation by designing institutions that make the right protected by duty (I) as secure as reasonably possible against violations. The phrase, "against violations" is important to emphasize, as Type II-2 duties are about protection from deprivation, not fulfilling (or exceeding) a right. All I have done so far is expand the range of actions that are required to protect from deprivation. This is not created out of thin air, but rather is the result of logically

\footnotetext{
${ }^{41}$ Shue, "Afterword," 173.

42 Shue, "Afterword," 174 \& Shue, Basic Rights, 17.

43 Shue, "Afterword," 173.

${ }^{44}$ Shue, Basic Rights, 60.
} 
combining the initial expression of Type II-2 duties with a desire to make that expression less negative and less narrow, as well as a desire to make rights reasonably secure.

In his afterword, Shue labels his discussion of what is required to make rights reasonably secure as "an institutional turn in thinking about human rights." 45 To help explain the institutional turn, Shue offers an image of waves of duties to illuminate the relationship between rights and duties. This image originates from Jeremy Waldron who writes:

Each right is best thought of not as correlative to one particular duty (which might then be classified as a duty of omission or as a positive duty of action or assistance), but as generating successive waves of duty, some of them duties of omission, some of them duties of commission, some of them too complicated to fit easily under either heading. $^{46}$

As example of these waves in practice, Shue writes:

We may, for example, first tell others not to interfere with what a person has a right to. When we find them interfering anyway, we establish police to stop them. Then when the police turn out to be corrupt, we reeducate the police and go after the drug dealers who corrupted them. Going after the drug dealers may be possible only after defeating the incumbent politicians, which may depend on an uncorrupt judiciary. ${ }^{47}$

I would like to further explore how the successive waves can be organized under the umbrella of the tripartite framework.

To use the above example we state a duty to avoid (for example, to avoid assault), and then seek to protect in with police (a Type II-1 duty). However corrupt police (who are violating duties to avoid and duties to protect in their corruption) have to be retrained or replaced (a Type II-2 duty). The drug dealers make this difficult, so we have further Type II-2 duties to design institutions that curb the drug dealers' influence. Incumbent politicians are failing at

\footnotetext{
45 Shue, "Afterword," 166.

46 Jeremy Waldron, Liberal Rights, (Cambridge: Cambridge University Press, 1993), 25 \& 212-215.

${ }^{47}$ Shue, "Afterword," 156.
} 
their duties to avoid and protect, so there are both Type II-1 and Type II-2 duties to protect against this (for example, arresting the criminally corrupt, and designing a system that makes it harder to act corruptly). Part of this system is an "uncorrupt judiciary" which requires the same duties as needed to deal with corrupt politicians.

An important takeaway from his framework and from the image of waves, and a part that will play a large role in my project, is that changes are required in institutional design. In discussing the reactions of others, Shue writes:

Some scholar/activists have retained my suggested three underlying categories (avoid depriving, protect from deprivation, and aid the deprived) and given broader and more positive content to the second duty to protect. Others have proposed a typology containing a more constructive third category, "to respect, to protect, and to fulfill," where to fulfill rights clearly involves more than aiding those whose rights one has already violated and includes the creation of more effective institutions to see that rights are honored in the first instance. ${ }^{48}$

By expanding Type II-2 duties, I specify the "institutional turn" as well as incorporate the views of others. Shue would remind us, "Look at what it actually takes to enable people to be secure against standard, predictable threats to their rights-focus on the duties required to implement the right. ${ }^{49}$ Although I spend a lot of time discussing Type II-2 duties, I emphasize that this quote applies to all duties. Not only do we need to determine what it will take in terms of institutional design, but we also need to determine what it will take in terms of Type I avoidance and Type II-1 protection. We should not focus exclusively on institutional changes to the neglect of seeing how our individual actions may be violating a duty to avoid or failing to protect (Type II-1) by enforcing a duty to avoid. Shue quotes James Nickel who says, "Respect for and implementation of human rights becomes a goal, and something like consequential

\footnotetext{
48 Ibid., 159-160.

49 Ibid., 160.
} 
reasoning must be used to pursue this goal." ${ }^{50}$ To avoid confusion, Shue prefers "means/end, instrumental, or strategic reasoning." ${ }^{51}$ Shue advises, "One's goal is for everyone to enjoy everything they have a right to enjoy. One's next task is to figure out how this can be arranged and how to allocate tasks involved in the establishment and operation of the arrangements.. ${ }^{152}$

So far I have made the step of interpreting Shue to establish consistency between the original work and the afterword, and within the afterword itself. I have tried to remain consistent with what appears to be his intent while still offering an advancement on what he has written. This interpretation places a lot of weight on the word "reasonably" which is the subject to which I will now turn.

\section{Other Reflections on "Reasonably"}

As previously stated there is a Type II-2 duty to design institutions that make it as easy as reasonably possible to honor duties to avoid or as hard as reasonably possible to violate duties to avoid. In other words, there is a duty to make rights as secure as reasonably possible. By using "as secure as reasonably possible," I am selecting any arrangement whose overall security-enhancing benefits are not outweighed by its costs. The purpose of "reasonably" is to avoid a requirement to maximize and to avoid a narrow focus.

To begin with, a requirement to maximize is very difficult if not impossible to obtain. For example, to provide a maximal right to security (domestically) would require an enormous system of police forces and surveillance systems. Such a system would be extremely costly, and these financial costs alone would make it difficult to provide for other basic rights. Jeremy

\footnotetext{
${ }^{50}$ Ibid., 160.

${ }^{51}$ Ibid., 161.

52 Ibid., 161.
} 
Waldron describes homeland security as "a voracious ideal" stating, "there is no end to the resources that might have to be devoted to it." ${ }^{\text {"53 }}$ He adds, "There would be nothing left for any other social program, let alone for any other program associated with rights." ${ }^{154}$

Even in a society that could pay for the financial costs, we also have to consider the other burdens. Constant electronic surveillance and heavy police presence open up new arenas for rights violations. Under such an oppressive scheme, citizens would be vulnerable to restrictions on their liberty and blackmail. This shows why we must avoid a narrow focus. By aiming for maximum protection of a specific right, it is easy to lose track of the bigger picture. The bigger picture contains all of the basic rights to be protected. A threat to one basic right is a threat to all others, so it is self-defeating to maximize protection of one basic right at the expense of another. I should note that I am not saying that we should maximize the protection of a package of basic rights. This would introduce the problem of having to define what it would mean to maximize the package of rights. Instead, all basic rights need only be reasonably guaranteed.

Furthermore, under the maximal pursuit of security, even the right of security may be jeopardized in that over-empowered police are at risk to directly violate the security of the very people they are supposed to protect. We can see the potentially self-defeating pursuit of maximal security in that increasing security for one group is often accomplished by decreasing security for another group. Waldron offers as evidence the fate of tortured prisoners in

\footnotetext{
53 Jeremy Waldron, "Security as a Basic Right (After 9/11)," in Global Basic Rights, edited by Charles Beitz and Robert Goodin, (Oxford: Oxford University Press, 2009), 218.

${ }^{54}$ Ibid., 219.
} 
Guantanamo Bay, "black" prisons in Eastern Europe, and those who have been "rendered" to foreign countries. ${ }^{55}$ There is the danger of making similar tradeoffs with a state's own citizens. Outside of basic rights, should we consider the effect of sustaining rights on things like human flourishing or other social values? For example, every dollar spent on rights is a dollar less spent on education or the arts. "Reasonably" could allow us to give weight to these considerations as well. I don't think basic rights ought to be sacrificed to obtain these other goods based on the fact that the ability to attend school or a musical performance is probably of much less concern to someone who is in danger of starvation or faces grave threats to their security. I share this belief with Shue. He would not support sacrificing basics rights for "nonbasic rights" or for the sake of "cultural enrichments, but he also does not think that such sacrifices will be required to uphold basic rights. ${ }^{56}$ On the view of both Shue and I, reasonably secure basic rights are necessary to enjoy other rights such as education or enrichments such as the arts.

Another question to ask: should "reasonably" be applied across the board or on a rightby-right basis? By this I mean, should a reasonable guarantee be a set percentage of a maximum guarantee or a specific percentage of a likelihood of being violated and all rights be guaranteed at that same percentage? Or instead, should what is reasonable be determined for each right? Some rights might be more easily secured than others. As previously quoted, Shue expands beyond security and subsistence to include "freedom of physical movement, as well as the liberty of economic and political participation. ${ }^{157}$ Part of political participation is the right

\footnotetext{
${ }^{55}$ Waldron, "Security," 226.

${ }^{56}$ Shue, Basic Rights, 114.

${ }^{57}$ Ibid., 65 \& 81-82.
} 
to vote. A right to vote can probably be more easily secured than a right to physical security. ${ }^{58}$ For example, to secure a right to vote, we would need to provide secure access to polling places or virtual polling places, and ensure privacy of the selections that people make, but only for a few days a year. On the other hand, as previously quoted, a right to physical security requires "police forces; criminal courts; penitentiaries; schools for training police, lawyers, and guards; and taxes to support an enormous system for the prevention, detection, and punishment of violations of personal security." ${ }^{\prime 59}$ This does not even include the aid that would be required when such protection failed. All of this would need to be provided each day. Based on the requirements, a right to vote could be made very secure (close to maximally secure) much more easily than could a right to physical security. To hold a right to vote and a right to security to the same likelihood of being violated would make a right to vote less than reasonably secure, or would make a right to security violate the constraint of reasonability. Instead we should apply the requirement of "reasonably secure" to each right individually.

Would such an interpretation be supported by Shue? How does he intend for "reasonably" to be applied? There is some evidence that Shue would support applying "reasonably" to each right individually. He writes:

Institutional design must combine judgments about what it is fair to expect people to do, what it is efficient to ask people to do, and what it is possible to motivate people to do. All this depends on subtle judgments about sense of duty, sense of fairness, sense of identity, sense of solidarity, self-interest, incentives, and coercion-especially hard choices about which aspects of individuals and societies can be changed while others remain fixed. ${ }^{60}$

\footnotetext{
${ }^{58}$ I thank Tal Brewer for the example of the right to vote.

${ }^{59}$ Shue, Basic Rights, 37-38.

${ }^{60}$ Shue, "Afterword," 170.
} 
Shue does not use "reasonably" or any synonyms in this quote, but the necessity of "subtle judgments" and "hard choices" suggests that he thinks a consistent across-the-board approach will fail. By judging what is reasonable for each right individually instead of for all rights collectively we are more likely to get these tough choices correct. Elsewhere Shue suggests that there is no one right answer to what institutions we need and that any answer will vary: From no theory like the present one is it possible to deduce precisely what sort of institutions are needed, and I have no reason to think that the same institutions would be most effective in all places and at all times. On its face, such universality of social institutions is most improbable, although some threats are indeed standard. ${ }^{61}$

This lends credence to applying "reasonably" differently to each right in each historic circumstance. Furthermore, regarding a specific right, or even regarding a specific threat to that right, there are no static answers to what needs to be combated let alone how to combat it. For example, what threats can be considered "ordinary" and are "feasible to counter" is an empirical question and subject to change. ${ }^{62}$ Shue continues, "What is, for example, eradicable changes, of course, over time. Today, we have very little excuse for allowing so many poor people to die of malaria and more excuse probably for allowing people to die of cancer." ${ }^{63}$ In short, what is reasonable may change just as what is eradicable can change. In sum, these excerpts suggest that Shue is more likely than not to support applying "reasonably" to each right individually. However, there is no definite articulation of him addressing this issue. I, however, have directly confronted the issue, and as previously shown, I believe that "reasonably" should be applied to each right.

\footnotetext{
${ }^{61}$ Shue, Basic Rights, 17.

62 Ibid., 33.

63 Ibid., 33.
} 


\section{Scanlon, Aristotle, and Precision}

It is an understatement to say that I am not alone in using the word "reasonably." One concern is that it can be a vague term. In What We Owe to Each Other, T. M. Scanlon gets a lot of mileage out of "reasonably" without ever giving a precise definition. Scanlon's central principle is that "An action is wrong if it would be excluded by any principles that no one could reasonably reject given the aim of finding principles that others, similarly motivated, could also accept." ${ }^{64}$ I do not intend to thoroughly discuss Scanlon's theory, but I would like to demonstrate a benefit of its vagueness.

In defending his account against charges of circularity, Scanlon relies on the fact that "much more is left open" than in an alternative account and that by being more precise it would negatively impact the "generality of the theory." ${ }^{65}$ I support the idea that the inherent flexibility provided by the vagueness of his theory is a strength not a weakness, and rather than destroy the theory, it may actually bolster it. In using the term "reasonably" I intend to rely on the flexibility it provides. Although a tidy formula may not require us to wrestle with slippery concepts, a tidy but inflexible theory may straightjacket us into ignoring what should be relevant concerns.

In a similar manner, Aristotle warns us to "not look for the same degree of exactness in all areas, but the degree that accords with a given subject manner and is proper to a given line of inquiry." ${ }^{66}$ He claims we must do this "so that digressions do not overwhelm our main

\footnotetext{
${ }^{64}$ T. M. Scanlon, What We Owe to Each Other (Cambridge: The Belknap Press of Harvard University Press, 1998), 33.

${ }^{65}$ Ibid., 218.

${ }^{66}$ Aristotle, Nicomachean Ethics, In Classics of Moral and Political Theory, $4^{\text {th }}$ ed., edited by Michael Morgan (Indianapolis: Hackett Publishing, 2005), Bk 1, CH 7 (1098a27-29). See also Ibid., Bk 1, CH 3 (1094b12-28).
} 
task." ${ }^{67}$ Whether from Scanlon or Aristotle, Shue and I have allies who support relying on a vague term such as "reasonably."

\section{Is the Tripartite Framework Applicable in the International Arena?}

Should we apply the tripartite framework, especially duties to protect, in what many theorists consider to be a state of nature? I am attempting to take a theory that is applicable in one realm and apply it in a new realm. Can the theory make such a jump? Many political realists believe that although morality is applicable on an interpersonal level, it is not applicable on the international level, due to the fact that the international arena is a state of nature lacking a central governing authority. In the same way, critics could complain that I am committing a category mistake by applying the framework to just war theory, and in particular state rights within just war theory. At a broad level, I disagree with political realists by subscribing to just war theory, although, I won't take up such arguments here. I also disagree with political realists in that I think the tripartite theory is applicable to just war theory in particular and state interaction in general. In more specific terms, I will argue as to why specific duties to protect are applicable in the international arena?

Shue writes that in a "wilderness situation" with "infrequent and irregular" interaction there may be "some point" in exclusive focus on duties to avoid. ${ }^{68}$ He continues, "But in an organized society, insofar as there were any such things as rights to physical security that were distinguishable from some other rights-to-be-protected-from-assaults-upon-physical-security, no one would have much interest in the bare rights to physical security. What people want and

\footnotetext{
67 Ibid., Bk 1, CH 7 (1098a36-37).

${ }^{68}$ Shue, Basic Rights, 38.
} 
need ... is the protection of their rights." ${ }^{69}$ This idea is not unique to Henry Shue. John Locke proposed that the reason why humans leave a state of nature is that they don't want just a bare right to property, but rather they want to enjoy the right to property. In a state of nature, "the enjoyment of it is very uncertain," but the right is much more secure if he is able to "join in society with others." ${ }^{\prime 70}$

Within the social contract tradition, ensuring the enjoyment of a right is often put forward as an argument for justifying a state and its associated powers. Why do I go a step further and also use it as an argument for the duties to protect outlined in the tripartite framework? While I think the goal of ensuring the enjoyment of rights is an excellent justification for a state, merely having a state is not enough to protect those rights. In some terrible states, citizens would be better off in a state of nature since their state may not only fail to protect rights, but the state itself may be a violator of rights. That people want protection of their rights is justification not just for a state, but more importantly, for requiring protective duties to guarantee those individual rights.

My interpretation is also consistent with what Shue has to say. Although he opined that in a state of nature there may be "some point" of exclusive focus on duties to avoid, he does not deny the existence of other duties, even in a state of nature. Elsewhere, he implies that that something akin to duties to protect exist prior to the creation of a state or effective institutions. He maintains, "That a right involves a rationally justified demand for social guarantees against standard threats means, in effect, that the relevant other people have a

\footnotetext{
${ }^{69}$ Ibid.

70 John Locke, Second Treatise of Government, in Classics of Moral and Political Theory, $4^{\text {th }}$ ed., edited by Michael Morgan, (Indianapolis: Hackett Publishing, 2005), Ch 9 (717-718).
} 
duty to create, if they do not exist, or, if they do, to preserve effective institutions for the enjoyment of what people have rights to enjoy."71 ${ }^{71}$ efore there is a state (or other effective institutions), duties to protect already exist.

Although the international arena without a supranational authority is often compared to a state of nature, I will make the case that the framework still applies. Drawing from Shue's insights, we should use interaction and organization, not central governance, as the relevant triggering conditions for duties to protect. Interaction is clearly met in today's "global village." Also, the international system is highly organized, and just war theory and international law are examples of that organization. Just as individuals in a society need protection of their rights, states also need protection of their rights. This is the case, because, just as we cannot trust individuals to avoid assault, we cannot trust states to avoid aggression. If a state is to exercise any rights, basic state rights to territorial integrity and political sovereignty must be protected. The specific duties that protect state rights are different, but the requirement to have duties to protect is the same. In the next chapter, I will show that just war theory attempts to protect state rights, but that in its current formulation, it is still lacking. That rights must be protected is why the duties to protect required by the tripartite framework are not only applicable, but necessary in the international arena.

\section{Shue's Critics}

Beitz and Goodin mention two general critiques of Shue's framework. The first is that it is too myopic: "Why stop with Shue's three types of duties? Surely there might be other kinds of actions or omission, in addition to forbearance, protection, and aid, that would reduce the

\footnotetext{
${ }^{71}$ Shue, Basic Rights, 17.
} 
chance of a right's being violated or increases the chances of a violation being remediated."72

This objection, if upheld, may require adding other duties to Shue's tripartite framework. Beitz and Goodin write, "Consider, for example, investment in economic infrastructure aimed at improving a society's productive capacity: under some circumstances this might be the most effective way to reduce severe poverty, yet it does not fit easily into any of the three categories of duties." 73 This is described as "a friendly objection in the sense that it seeks to extend the reach of Shue's own insight about the structure of duties." 74

In response, I argue that Shue does not claim that only the actions required by the tripartite framework could have an effect on basic rights. Rather, he offers a minimum set of actions that are required to fulfill rights. If aid is required, improved economic infrastructure may allow for more resources to be available for distribution. However, aid is usually an issue of choosing to distribute resources rather that whether enough resources exist. Shue's framework can secure a right without requiring improved economic infrastructure. Furthermore, improved economic infrastructure without an accompanying will to use that infrastructure to fulfill rights may just increase the opportunities for the powerful to exploit the vulnerable. Shue is not completely opposed to expanding his framework, however. In two locations he suggests a possible additional category using the phrase, "whatever other general categories of duties," and in another location "whatever others are needed."75 Most importantly for my project, Shue's framework already requires enough duties to support my

\footnotetext{
${ }^{72}$ Beitz \& Goodin, “Introduction," 13.

${ }^{73}$ Ibid.

74 Ibid.

${ }^{75}$ Shue, "Afterword," 170 \& 171.
} 
desired modifications to just war theory. Adding to his framework would not endanger my argument so this critique is not an issue.

The second critique that Beitz and Goodin share runs in the opposite direction. It "holds that there is a significant difference between rights for which a complete assignment of duties can be given and those for which the assignment of duties is necessarily incomplete, and that this distinction supervenes on the distinction between security and subsistence.."76 For example, within security rights everybody has a duty to not assault, and if assault occurs it is easy to claim that a specific person has violated a duty (of course sometimes the identity of that person is unknown). However, if subsistence rights are violated, it is much more difficult to determine who is to blame.

Onora O'Neill is a proponent of this critique. She takes a Kantian perspective and disagrees with the idea of treating rights as fundamental and thus making obligations "the subordinate notion."${ }^{177}$ Instead she believes we should start with certain obligations and those obligations will determine what a genuine right is. A right must have a corresponding obligation assigned to another such that the right holder can claim or waive the right. She adds:

Unless obligation-bearers are identifiable by right-holders, claims to have rights amount only to rhetoric: nothing can be claimed, waived, or enforced if it is indeterminate where the claim should be lodged, for whom it may be waived or on whom it should be enforced. This condition can be met for universal rights when they are matched by corresponding universal obligations that are allocated to all others, and for special rights when they are matched by corresponding special obligations that are allocated to specific others. ${ }^{78}$

\footnotetext{
${ }^{76}$ Beitz \& Goodin, “Introduction," 13.

${ }_{77}^{77}$ Onora O'Neill, Towards Justice and Virtue, (Cambridge: Cambridge University Press, 1996), 128.

${ }^{78}$ O’Neill, Towards, 129
} 
Based on this, O'Neill considers a non-special right (universal right or human right) to only exist when there are universal obligations required by all others. This is one feature that separates liberty rights from rights to goods or services. She states, "Liberty rights do not need institutional structures to be claimable and waivable. By contrast rights to goods and services can be claimed or waived only if a system of assigning agents to recipients has already been established." ${ }^{79}$ She would argue we don't need a system to tell us that all people have a duty to not assault. However, for subsistence rights, we would need a system to assign the various duties that support such a right.

Relatedly, the other feature separating the two is that liberty rights simply "demand noninterference" while rights to goods or services "demand a specific performance." ${ }^{80}$ For example liberty rights could be covered by universal negative obligations, but a universal right to subsistence would require assigning a claim for each right to people or institutions. ${ }^{81} \mathrm{O}^{\prime}$ Neill supports the commonly help distinction (denied by Shue) that liberty rights are negative rights, and subsistence rights are positive rights.

Elizabeth Ashford takes O’Neill to draw a distinction “between the primary duties imposed by rights - that is, duties to respect rights, the violation of which constitutes a right's violation-and secondary duties, the role of which is to enforce compliance with those primary duties." ${ }^{82}$ O'Neill would claim that the primary duties are negative duties, but that the secondary duties would be positive. Ashford later adds, "The role of institutions is simply to

\footnotetext{
${ }^{79}$ Ibid., 131.

${ }^{80}$ Ibid., 130 (footnote 4).

${ }^{81}$ Ibid., 130-131.

82 Elizabeth Ashford, "The Alleged Dichotomy Between Positive and Negative Rights and Duties," in Global Basic Rights, edited by Charles Beitz and Robert Goodin, (Oxford: Oxford University Press, 2009), 103.
} 
enforce these antecedently specified duties." 83 O'Neill and Shue approach the problem from opposite sides. She starts with universalizable duties ("obligations" in her words), and she derives rights from those duties. ${ }^{84}$ In contrast, Shue starts with basic rights and from there allocates duties to fulfill those rights. My approach is also to start with rights and then determine what duties are necessary for right fulfillment.

Although O'Neill claims different rights than Shue does, she agrees with him when it comes to enforcement, stating:

Henry Shue for example correctly pointed out that once we start talking about the enforcement of rights, the distinction between liberty rights and substantive economic rights which require positive action from others fades [...] However, enforcement presupposes that the proper allocation of obligations has been identified. It is, after all, obligations, and not rights, that will need enforcing. Arguments from the demands of enforceability cannot settle who holds the obligations that would correspond to supposed rights to goods and services. ${ }^{85}$

O'Neill does leave room for positive duties, at least when it comes to enforcement. Elsewhere, she writes, "The most impeccable liberty rights, such as the right to not be tortured, cannot be implemented without a legal system and institutional structures for supervising police, courts and penal institutions." ${ }^{86}$ The significance of this dispute is that $\mathrm{O}^{\prime}$ Neill would not agree with Shue's claim that subsistence rights are equivalent to security rights and thus both are equally basic rights. She would not support Shue's application of the tripartite framework to subsistence rights.

Fortunately, although I rely on Shue's framework, I do not rely on subsistence rights. O'Neill's critique thus does not affect my argument. In fact, although she may not have the

\footnotetext{
${ }^{83}$ Ashford, "Dichotomy," 103.

${ }^{84}$ Onora O'Neill, Bounds of Justice, (Cambridge: Cambridge University Press, 2000), 136.

${ }^{85}$ O'Neill, Bounds, 135-136. See also, O'Neill, Towards, 131.

${ }^{86}$ O’ Neill, Towards, 131.
} 
same conception of enforcement that Shue does, she would support enforcing Shue's security rights. Whether to side with Shue or O'Neill depends on whether one wants to start with rights or duties. I find it intuitively more helpful to start with universal needs. As it turns out, however, her criticism does not affect my ultimate aim.

In sum O'Neill is not too critical of the parts of Shue I need. Specifically, she believes in rights against, torture, murder, rape, etc. ${ }^{87}$ She also agrees that if we want to enforce these rights, institutions are needed. What she lacks is the robust framework that Shue adds, but at least at the domestic level, the duties she needs to enforce a right to security concur with what Shue requires, as well as with common sense. That these two critiques leveled at Shue do not affect my ultimate aim gives me a stronger foundation upon which to build my project. The biggest reason I am able to avoid the issues that are leveled at Shue is that I rely on security rights and not the more controversial subsistence rights.

Shue justifies protecting individual subsistence rights as an analogy with protecting individual security rights. In the next chapter, I will justify protecting state security rights as an analogy with protecting individual security rights. I rely on Shue's tripartite framework which he often illustrates via subsistence examples; however I do not rely on a right to subsistence to justify protecting state security rights. Thus, those who disagree with Shue's view that individuals have a right to subsistence, or do not want to grant that such rights should be protected by the positive duties included in the tripartite framework, do not attack my position. Furthermore, I would like to add that a state right against aggression could be universalizable as a duty for all others to avoid aggression. In addition, a right against aggression also only asks

${ }^{87}$ O’Neill, Bounds, 104-105, \& 135. See also O'Neill, Towards, 131. 
for non-interference. As such, it appears O'Neill could support a universal state right against aggression. 


\section{Chapter Four: Shue's Tripartite Framework and Just War Theory \\ Introduction}

In this chapter, I will apply Shue's Tripartite Framework to just war theory. Initially, I will integrate the two by placing the duties recognized by the prevailing view of just war theory within Shue's framework. Just war theory assigns duties to states and combatants, and these duties are supposed to uphold the rights that it claims to protect. However, when it comes to the Type II-2 duties of states, problems arise. States have a Type I duty to avoid aggression, and a related Type II-2 duty to design institutions that make the right protected by duty (I) as secure as reasonably possible against violations.

If SCO were legally allowed, it would give rise to a powerful impediment to state aggression. If combatants ordered to fight an aggressive war objected, this would make fighting aggressive wars more difficult. The difficulties posed by such objections would help to dissuade states from starting aggressive wars. I will further argue that just war theory should morally require $\mathrm{SCO}$ as a means to make the right against aggression as secure as reasonably possible against violations. Contrary to the prevailing view of just war theory, combatants have duties to avoid and duties to protect that are necessary to fulfill state rights. This will have a cascade of effects which will modify the prevailing view of just war theory and morally empower combatants. In regards to a state's Type II-2 duties and a combatants Type I and Type II-1 duties, I will significantly revise the status quo. 


\section{The Duties of Just War Theory within Shue's Tripartite Framework}

I will begin by analyzing the duties to avoid and protect as currently conceived in the prevailing view of just war theory. ${ }^{1}$ Let's start with Walzer's assumption that states have a right to political sovereignty and territorial integrity and individuals have a right to life and liberty. ${ }^{2}$ Violating political sovereignty or territorial integrity is aggression, and under just war theory, a state has a duty to avoid aggression. A state also has a duty towards all combatants and noncombatants to avoid aggression. Although aggression is first and foremost a crime against another state, it is also a crime against individuals in that aggression "force[s] men and women to risk their lives for the sake of their rights," or in the case of non-combatants places them at risk of suffering harm. ${ }^{3}$ Aggression downgrades the right to life of combatants and noncombatants on all sides to those lesser rights prescribed by jus in bello. As shown previously, just war theory's jus in bello holds that combatants have a right to not be targeted with unnecessary or disproportionate force and that non-combatants may not be killed directly, intentionally, or disproportionately. Both of these are Type I duties states have.

Combatants also have Type I duties. Although the prevailing view of just war theory does not state that combatants have Type I duties to other states, the prevailing view does accept that combatants have duties towards combatants and non-combatants. As mentioned above, combatants are not to be targeted with unnecessary or disproportionate force and noncombatants are not to be killed directly, intentionally, or disproportionately. In sum, here is a chart of the "duties to avoid" recognized by the prevailing view of just war theory.

\footnotetext{
${ }^{1}$ I will for the most part, ignore duties to aid to limit the scope of the topic.

${ }^{2}$ Walzer, Wars, 44.

${ }^{3}$ Ibid., 51.
} 


\begin{tabular}{|c|c|c|}
\hline $\begin{array}{c}\text { Duty Bearer } \\
\text { State }\end{array}$ & Right Holder & $\begin{array}{c}\text { Type I Duty to Avoid } \\
\text { Other States }\end{array}$ \\
\hline State & Other Combatants & Avoid aggression \\
\hline State & All Non-Combatants & Avoid aggression, avoid killing directly, intentionally, or disproportionately \\
\hline Combatants & Other States & None exists \\
\hline Combatants & Other Combatants & Avoid killing unnecessarily, or disproportionately \\
\hline Combatants & All Non-Combatants & Avoid killing directly, intentionally, or disproportionately \\
\hline
\end{tabular}

I will now analyze Type II duties starting with Type II-1 duties to protect by enforcing duties of avoidance discussed above. I am the first that I know of to apply Shue's framework to just war theory. The next pages discuss the Type II-1 duties that would be required if the prevailing view of just war theory were combined with Shue's framework. Most of these are already supported by just war theory or state and international law.

According to the prevailing view, a state has no Type II-1 duty to enforce the prohibition against aggression. Unlike domestic society, where police primarily enforce duties to avoid, each state (along with any allies) is usually responsible for protecting itself. ${ }^{4}$ Despite this, a state does have a duty to all other combatants and non-combatants to prevent and prosecute violations of jus in bello, for which they have responsibility. A state may realize that its soldiers in a specific war are more likely to violate jus in bello when fighting in crowded urban environments. An order emphasizing that lower-level commanders are to take action to prevent such atrocities is an example of acute prevention. Recall from the last chapter, that protection must be against both acute and chronic threats. Combatants have no duty to protect an enemy state from aggression, but they do have duties to protect enemy combatants and non-combatants from violations of jus in bello by preventing and reporting violations of jus in bello.

\footnotetext{
${ }^{4}$ The exception to this general rule occurs for humanitarian interventions.
} 
So far I have only discussed what states or combatants owe to other states or to another state's citizens. However states and combatants also have duties to their own state and allied states, as well as to citizens of those states. In order to protect its state rights to political sovereignty and territorial integrity, a state has a duty to protect the state entity itself (and any allied state) from aggression. ${ }^{5}$ Relatedly, a state has a duty to its citizens and allied citizens (both non-combatants and combatants) to protect them from aggression. Finally, a state also has a duty to protect its combatants and non-combatants against violations of jus in bello. A demonstration of how this is different from protecting against aggression is that even an aggressor state would have a duty to protect its civilians from violations of jus in bello. This would imply, for example, that a German soldier in WWII would have a duty to protect German civilians from direct, intentional, or disproportionate attacks by allied forces even though the Germans were the aggressors. As Walzer puts it, "The law can be enforced even by criminal states against 'policeman' who deliberately kill innocent bystanders. For these bystanders do not forfeit their rights when their states wrongly go to war." ${ }^{6}$ Jeff McMahan concurs saying, "If a Japanese pilot could have shot down the Enola Gay before its crew dropped the atomic bomb on Hiroshima, he would have been morally justified in doing so, despite the fact that he was an unjust combatant while the crew of the Enola Gay were just combatants."7

Military acts of defense could be viewed as aid (oftentimes self-provided) to those states or individuals that have had their rights violated. There may even be clear-cut cases where this is the better view. However, I think it is often better to view such acts as protection.

\footnotetext{
${ }^{5}$ Alternatively, some states seek allies to provide the protection. Still the state at least ensures it is protected, even if it does not provide it for itself.

${ }^{6}$ Walzer, Wars, 136-137.

${ }^{7}$ McMahan, Killing, 16.
} 
Consider a state that is initially attacked in a specific city on its border. Armed defense is trying to restore the political sovereignty and territorial integrity of that city, but, more importantly, armed defense is protecting the political sovereignty and territorial integrity of the rest of the country from further aggression. In the same way, although armed defense may aid citizens already victimized, more importantly it protects others from aggression and those already victimized residents from further aggression. This belief is shared by Orend who references McMahan saying, "Even when we go to war in response to an attack which has already occurred, a prime objective in doing so is to prevent even further damage inflicted by the attacker." $^{\prime 8}$

A combatant has the same duties to their state and to compatriots as the state does. Recall that a combatant is distinguished from non-combatants by bearing arms and posing a danger to others. ${ }^{9}$ Some may think that all citizens (not just combatants) may have a moral duty to protect each other as best they are able, but this is certainly not the prevailing view of just war theory. According to the prevailing view, non-soldiers who protect others or themselves with force become legitimate targets and lose the protection that just war theory and international law would provide them. A combatant has a duty to protect the state as well as protect fellow citizens (both combatants and non-combatants) from aggression. Finally a combatant also has a duty to protect compatriots from violations of jus in bello. Below is a chart summarizing the Type II-1 duties to protect by enforcing duties to avoid.

\footnotetext{
${ }^{8}$ Orend, War, 77. Orend's reference to McMahan was for a "forthcoming" publication that in actuality did not contain an article by McMahan.

${ }^{9}$ Walzer, Wars, 145.
} 


\begin{tabular}{|c|c|c|}
\hline Duty Bearer & Right Holder & Type II-1 Duty to Protect By Enforcing a Duty to Avoid \\
\hline State & Other States & None Exists \\
\hline State & Other Combatants & Prevent/Prosecute jus in bello violations \\
\hline State & Other Non-Combatants & Prevent/Prosecute jus in bello violations \\
\hline Combatants & Other States & None Exists \\
\hline Combatants & Other Combatants & Prevent/Report jus in bello violations \\
\hline Combatants & Other Non-Combatants & Prevent/Report jus in bello violations \\
\hline State & Own/Ally States & Protect from aggression \\
\hline State & Own/Ally Combatants & Protect from aggression and jus in bello violations \\
\hline State & Own/Ally Non-Combatants & Protect from aggression and jus in bello violations \\
\hline Combatants & Own/Ally States & Protect from aggression \\
\hline Combatants & Own/Ally Combatants & Protect from aggression and jus in bello violations \\
\hline Combatants & Own/Ally Non-Combatants & Protect from aggression and jus in bello violations \\
\hline
\end{tabular}

The next duties to analyze are Type II-2 duties to protect by institutional design. As reinterpreted in the previous chapter, Type II-2 duties require that we design institutions that make the right protected by duty (I) as secure as reasonably possible against violations. The next paragraph discusses the Type II-2 duties that would be required if the prevailing view of just war theory were combined with Shue's framework. Most of these are at least partially supported by just war theory or state and international law.

Although all citizens (including combatants) in a democratic state have some ability to influence institutional design by political action, I will primarily analyze Type II-2 duties as ones that are borne by states and other institutional designers (politicians, academics, etc.). A state has a duty to all states (including themselves) to design institutions (both international and national) that discourage aggression and allow for self-defense. The primary method to discourage aggression is through deterrence by the threat of self-defense and other-defense. A state also has a duty to all combatants and all non-combatants to create a system that discourages aggression and allows for self-defense. Finally, a state also has a duty to all combatants and all non-combatants to create institutions that discourage violating jus in bello 
requirements. Examples of institutional design in preventing chronic jus in bello threats include creating a syllabus for teaching jus in bello during training and establishing a system for reporting and prosecuting violations. Here is a chart of the Type II-2 duties that states owe.

\begin{tabular}{|c|c|c|}
\hline Duty Bearer & Right Holder & Type II-2 Duty to Protect by Institutional Design to \\
\hline State & All States & Discourage aggression/allow self-defense \\
\hline State & All Combatants & Discourage aggression/allow self-defense/discourage violating jus in bello \\
\hline State & All Non-Combatants & Discourage aggression/allow self-defense/discourage violating jus in bello \\
\hline
\end{tabular}

Thus far I have fleshed out how the duties of the prevailing view of just war theory fit within

Shue's framework. Now we must turn to the question: Are the duties espoused by the prevailing view of just war theory enough to make the related rights as secure as reasonably possible against violations?

At the level of institutional design, conflict can be seen between what actually occurs and what the prevailing view of just war theory would require when analyzed by Shue's tripartite framework of duties. Shue's theory requires that we design institutions that discourage states from committing aggression, thereby making basic rights as secure as reasonably possible against violations. On inspection, this does not occur. I will begin by looking at state law.

\section{State Law}

A state has a moral duty of institutional design to make a right against aggression as secure as reasonably possible against violations. One action that would contribute to this end is a legal allowance to SCO. Such a change to state law would make it more difficult for states to violate a right against aggression. It is as if the state is saying, "We so strongly believe in the tenets of jus ad bellum that we allow our subordinates to object if we order them to violate it." 
In many bottom-up arguments, a legal allowance of SCO provides those who oppose a specific war a way to reconcile their personal beliefs with the requirements of their state. It allows them to avoid fighting. However, I am not considering SCO from the perspective of accommodating a combatant's conscience, but rather from the perspective of designing institutions to discourage aggression. ${ }^{10}$ SCO would work in two ways. First, it would discourage states from ordering combatants to fight in an aggressive war. Second, if such an order were given, it would be less effective as many would not comply.

As I show below, other theorists have acknowledged the potential for SCO to deter aggression, but my argument is unique in that I am concentrating on this as an independent reason to argue for SCO. Most others, however, view deterring aggressive wars merely as a positive side effect of shifting views regarding MEC and SCO. I view deterring aggression as the desired effect and as a self-standing reason for SCO. Closest to my view, Gregory Foster views deterring aggressive wars as one reason for SCO, however he only argues for a legal allowance and not a moral duty to object (for which I will ultimately argue). Also, he does not reference state rights. ${ }^{11}$ Similarly, most of the below theorists argue from the bottom-up. My top-down argument is unique in that this desired effect is sought in order to protect state rights. Below are what some other theorists have to say regarding the effect of SCO on deterring aggression.

\footnotetext{
${ }^{10}$ As I am deriving a combatant's allowance to SCO from a state's duty to discourage aggression, I will only consider SCO for wars that are aggressive (i.e. lack a just cause). A topic for future reflection is whether to also include wars that have a just cause, but fail to meet other jus ad bellum requirements.

${ }^{11}$ Gregory Foster, "Selective Conscientious Objection," Society, 46:5 (2009): 390-393. Foster presents this as the second of three reasons to legalize SCO. His first reason is that combatants should have a legal right to object as a way to withdrawal, if the government does not uphold their part of the contract. His final reason is that it would encourage combatants to be more "civically engaged" and rely on reason instead of dogmatic belief.
} 
Jeff McMahan paints a picture of what he thinks would occur if objecting to an

aggressive war became the moral norm, and a state had to make "institutional

accommodations" to that norm:

In that altered institutional environment, governments could expect to encounter increased risks of resistance to their efforts to initiate unjust wars. And the prospects of resistance, particularly from within the military, and the consequent risks of humiliation and failure, could deter at least some attempts to initiate unjust wars that might at present seem positively appealing and advantageous even for domestic political reasons (For example, because even initially unpopular wars ignite people's patriotic sentiments once they have begun, thereby prompting at least temporary support for the government). ${ }^{12}$

Jeff McMahan is not the only philosopher who believes that SCO would have this effect.

Brian Orend also believes that SCO would "make it more difficult for a regime to mount an aggressive war," and that "states would be seriously hampered [...] in their efforts to prosecute an aggressive war." ${ }^{13}$ Paul Robinson states, "Selective conscientious objection might limit the ability of governments to wage wars which very large numbers of their own soldiers consider unjust, and one might therefore regard it as a sort of tripwire, warning governments and the public when they are engaging in morally dubious activities." ${ }^{14}$ Robinson also adds that acts of SCO can contribute to encouraging moral debate. ${ }^{15}$ Gregory Foster believes that SCO "would serve [...] as a much-needed internal compass for U.S. war-making," and "legalizing the practice would embolden those in uniform - war's ultimate stakeholders - who object to wrongful and wrong-headed wars to express their opposition formally." ${ }^{16}$ Finally, although ultimately arguing against SCO, Cheyney Ryan gives examples of the power of combatant resistance helping end

\footnotetext{
${ }^{12}$ McMahan, Killing, 7.

${ }^{13}$ Orend, War, 135 \& 108.

${ }^{14}$ Robinson, Paul. “Integrity and Selective Conscientious Objection," Journal of Military Ethics, 8:1 (2009): 43.

${ }^{15}$ Ibid., 44 .

${ }^{16}$ Foster, "Selective," 392.
} 
World War I and the Vietnam War. He writes, "The end of World War I was marked by mutinies of soldiers of all the major belligerents," and "An important factor in ending the Vietnam War was the unprecedented resistance of ordinary soldiers." ${ }^{17}$

Despite thinking that SCO might help prevent an unjust war, both Robinson and Orend think the number of objectors would be low. Robinson, however, adds, "unless the war is quite egregiously unjust.." ${ }^{18}$ I am more hopeful, considering that reasons to currently doubt the number of objectors stem from state law prohibiting objecting and the prevailing view of just war theory insisting that a combatant is not blameworthy for participating in an unjust war. When these factors change and we morally empower combatants, we can likely expect a change in the number of objectors. Ultimately, we don't yet have much evidence as to how combatants would react; as McMahan says, "[SCO] has rarely been 'field tested."'19

Would it be even better for a state to not just allow SCO, but instead require it? Consider that a state does not merely allow citizens to contribute to funding the government, but rather requires it through taxes. Duties often accomplish more than mere allowances. However, the effectiveness of a duty instead of an allowance is not the only issue. In order for the government to punish soldiers for failure to object, it would have to recognize cases where it gave orders to fight that were illegitimate. However, if the government can recognize when orders are in error, it can avoid giving them. Now certainly in retrospect, a government can realize when its orders are in error. However, for a state to punish its own soldiers after the

\footnotetext{
${ }^{17}$ Cheyney Ryan, “Democratic Duty and the Moral Dilemmas of Soldiers," Ethics, 122:1 (2011): 12.

${ }^{18}$ Orend, War, 136 \& Robinson, "Integrity," 43.

${ }^{19}$ McMahan, Killing, 75 \& Robinson, "Integrity," 43.
} 
fact for participating in an unjust war seems both impractical and unfair. It is impractical, because it would be difficult and very expensive to conduct trials for all. ${ }^{20}$

As an argument for why it is unfair, consider this hypocritical (and satirical) statement from a government to its combatants explaining why they should be punished for their failure to object: "We are ordering you to do something that we have deeply considered. If, despite the depth of our consideration, we later determine that we are in error, we will punish you for failing to point that out at the time of the original order." It is asking those with less training and resources to do a better job (and sooner) at making a difficult decision than those who (via election and appointment) are supposed to make that decision. And then, if the subordinates fail to perform this task, they are punished, even if at the present they, like the government, consider their past actions to have been wrong. A state that punishes combatants for failing to object to orders to fight in an unjust war is imposing "the injustice of ex post facto prohibitions." ${ }^{21}$ To that I might add the hypocrisy of the state expecting more from its combatants than it does from itself. It is unfair for the government that issues an order to fight to punish soldiers who fail to object to it. Later, I will briefly discuss whether a state should considering punishing the decision makers who gave the order or the supporting cast who "gathered" and "analyzed" the evidence that supports such as order.

When we are talking about a duty given by a national government, we are talking about a legal duty, and any punishment would be a legal punishment. It is specifically this legal duty to

\footnotetext{
${ }^{20}$ This mirrors an argument by Jeff McMahan for why international law should not hold combatants responsible for fighting unjust wars. His arguments will be discussed shortly.

${ }^{21}$ Wertheimer, "Reconnoitering," 63.
} 
object and any related legal punishment that would be unfair. ${ }^{22}$ Although a legal duty of SCO would be unfair, as previously discussed, a state should allow SCO. The argument is that states have a moral duty of institutional design to make a right against aggression as secure as reasonably possible against violations.

\section{International Law}

State law is not the only institutional design that needs to be considered. I will now consider changes to the design of international law. Should international law either allow or require SCO? As to an allowance, it seems that all the same reasons that suggest a state has a duty to allow SCO would also apply to international law. However, unlike state law, international law does not exercise control over specific combatants, so there are no combatants for international law to allow to object. However, international law should require that all states allow SCO. Such a requirement would make a right against aggression more reasonably secure in that it would encourage states to allow SCO.

In regards to a duty to SCO, international law does not have to worry about the charge of unfairness due to hypocrisy. However, international law introduces other concerns. If international law proclaims a duty to object, then this would deny the legal equality of combatants (LEC). LEC states that, according to international law, combatants are considered equals and thus, whether just or unjust, the same permissions and restrictions apply to all combatants, and that combatants are not legally blameworthy merely for participating in an unjust war. However, if international law requires combatants to object to an unjust war, this

\footnotetext{
${ }^{22}$ Later I will discuss a moral duty to object.
} 
conflicts with not being legally blameworthy merely for participating. The concern is that there are very strong reasons not to deny LEC. I will affirm most of the same reasons given by Jeff McMahan to uphold LEC. ${ }^{23}$ These reasons also count against including a duty to SCO in international law, in that a duty of SCO would require denying LEC. By invoking these reasons, I hope to show that is not reasonable for international law to deny LEC or require SCO.

First, most combatants believe their side is just, so any easing of restrictions or granting of permissions intended only for just combatants would likely be assumed by unjust combatants as well. Likewise, the reduction of permissions or the increase of restrictions for unjust combatants will be ignored as most unjust combatants consider themselves to be just.

Second, punishing unjust combatants would create perverse incentives in that, due to the prospect of punishment, unjust combatants would be less likely to surrender (thus prolonging the war) and would be more likely to violate jus in bello in the hope of perhaps winning and avoiding punishment. ${ }^{24}$ I have not specified whether these punishments would be given by the International Criminal Court (ICC) or by an ad hoc court established by the victor (such as in Nuremberg). Certainly the perverse incentives are stronger if the only justice is victor's justice, and thus a soldier on the victorious side will never be brought to trial. However, even with the ICC, it will be much more difficult to bring the combatants of a powerful and victorious state to justice than those of a weakened and defeated state. Underscoring this is

\footnotetext{
${ }^{23}$ McMahan, Killing, 108 \& 190-192. I have not included McMahan's belief that due to the unlikely occurrence of recidivism, those punished would be unjustly used to deter others from fighting future wars. This relies on a specific theory of punishment that goes well beyond the scope of this paper.

${ }^{24}$ David Fisher, "Who Guards the Guards? The Importance of Civilian Control of the Military," in When Soldiers Say No, edited by Andrea Ellner, Paul Robinson, and David Whetham, (Burlington: Ashgate, 2014), 70. Fisher shares these first two concerns with McMahan.
} 
the fact that the ICC "relies on state cooperation" to conduct arrests as it does not have a police force. $^{25}$

Third, legal inequality would be difficult to enforce. There is not an impartial court empowered to enforce asymmetric laws of war, and even if there was, it would be impossible to give a fair trial to all due to the sheer number of combatants. After 2017 the ICC might exercise jurisdiction over the crime of aggression, but it currently does not. ${ }^{26}$ Furthermore, even if it does eventually exercise such jurisdiction, it would not likely include rank and file combatants. The ICC currently states that "The perpetrator of the act of aggression is a person who is in a position effectively to exercise control over or to direct the political or military action of a State." 27 What the ICC is empowered to enforce could of course change, but the difficulty of giving a fair trial to an extremely large numbers of combatants will likely not.

\section{Other Measures}

As we are evaluating institutions, we should ask: Does the institutional arrangement (proposed or existing) contribute to making the right as secure as reasonably possible against violations? I have just argued that state laws allowing SCO, and international law requiring states to allow SCO, would help meet this standard. Of course other measures might be imagined that would help to protect the international community against aggression. Is it possible that other measures could exclude SCO?

To decide whether a given measure should be included among options, we should consider its contribution to the end of reasonably securing rights. If one institutional

\footnotetext{
25 “International Criminal Court-Frequently Asked Questions." Accessed 19 October 2015. http://www.icccpi.int/en_menus/icc/about\%20the\%20court/frequently\%20asked\%20questions/pages/faq.aspx.

${ }^{26}$ Ibid.

${ }^{27}$ Ibid.
} 
arrangement was so effective that other arrangements were redundant, might this be a reason not to include others? It is possible that some other arrangement is so effective that there is not a need for combatants to object. Under such an arrangement states might not give orders to fight in an unjust war. This is theoretically possible, just as it is theoretically possible that someday police and courts would not be needed because people would perform their Type I duties, for example, by not committing assault. However, neither seems likely anytime soon. Even if such an arrangement existed, SCO could remain as a vestige of more troubling times. Eventually, it could be removed if no longer needed, but there are great reasons for having redundancy. In fact Shue's theory demonstrates the importance of redundancy. ${ }^{28}$ Type II duties are only needed if Type I duties are not performed. Aside from natural disasters, Type III "duties to aid" are only needed when Type I and Type II duties are not performed.

Another reason not to include an arrangement that on its own makes a right more reasonably secure against violations is, if in combination with other arrangements, that arrangement becomes counterproductive. We could imagine plant fertilizers designed to increase growth. Fertilizer A causes increased growth, and separately Fertilizer B also causes increased growth. However, when combined, the two fertilizers could neutralize each other or worse yet, inhibit growth. A chemist could probably create such a scenario and explain why it occurs. It remains an empirical question if multiple incentives against aggressive war could conflict like this. Not knowing what all the other possibilities are, or could be, it is difficult to pass judgment. However, we should not rule out a presently strong candidate based on the

\footnotetext{
${ }^{28}$ Shue, Basic Rights, 170-173.
} 
potential that some future candidate may conflict. If later evidence shows otherwise, things can be changed.

I will briefly mention other methods to make a right against aggression more reasonably secure against violations. The first and most obvious one is already in use: international law grants a right of self-defense. This, and the related deterrence, is the primary disincentive to aggression. Other methods include: repealing the resource privilege, repealing the borrowing privilege, limiting trade with states that start aggressive wars (both as an established treaty or an ad hoc response to aggression as it is already often used), limiting weapons trade with countries that start aggressive wars, punishing state leaders (and staff) that start aggressive wars, and continuing or instituting a draft. None of these seem likely to conflict with SCO. I will not spend too much time on these or other possibilities in order to keep my topic narrow, but they could be fruitful avenues for further research in making a right against aggression as secure as reasonably possible against violations.

First, I would like to briefly expand on the international borrowing privilege and the international resource privilege. Thomas Pogge explains these privileges:

Any group controlling a preponderance of the means of coercion within a country is internationally recognized as the legitimate government of this country's territory and people-regardless of how this group came to power, of how it exercises power, and of the extent to which it may be supported or opposed by the population it rules. That such a group exercising effective power receives international recognition means not merely that we engage it in negotiations. It means also that we accept this group's right to act for the people it rules and, in particular, confer upon it the privileges freely to borrow in the country's name (international borrowing privilege) and freely to dispose of the country's natural resources (international resource privilege). ${ }^{29}$

\footnotetext{
${ }^{29}$ Thomas Pogge, World Poverty and Human Rights, $2^{\text {nd }}$ edition. (Cambridge: Polity Press, 2008), 118.
} 
The problem with these privileges is that they encourage unjust regimes to come to power via unsavory means such as coups and civil wars. ${ }^{30}$

While there are situations where it is justified to overthrow a tyrannical government, there is a difference between coming to power to protect the rights of a people, and doing so in order to enrich one's own in-group. The borrowing and resource privilege encourages aggressive would-be-leaders to take over the state for their own benefit. Governments that demonstrate aggression against their own citizens are more likely to demonstrate international aggression; history is replete with examples such as Nazi Germany and Hussein's Iraq. ${ }^{31}$ Even if these criminal governments do not desire or are not powerful enough to commit international aggression, frequent government changeover can lead to regional destabilization which can foster aggressive war. Finally, such governments are less likely to contribute to supporting institutions against aggressive war. One area of concern is the expected political resistance to repealing these privileges. This would occur due to the potential effect on trade related to the likely increase in the cost of raw resources and their related goods. Of course, SCO is likely to encounter political resistance as well.

Somewhat related, an additional option is to limit or restrict trade with states that start aggressive wars or, more specifically, to limit weapons trade with such states. In addition to political motivation, a difficulty with the first option is that frequently sanctions can fail to respect the principle of discrimination. ${ }^{32}$ When a dictator who is not concerned with the fate of his own people is faced with limited resources, he will often take care of his in-group first, and

\footnotetext{
${ }^{30}$ Ibid., 119.

${ }^{31}$ Orend, Morality, 53-54.

32 Orend, Morality, 58 \& 214.
} 
leave others to suffer. This danger can be limited by tailored sanctions and direct aid from international organizations.

Regarding weapons trade, on April 2, 2013, the U.N. General assembly approved a global arms trade treaty via a 154-to-3 (North Korea, Iran, and Syria) vote with 23 abstentions (notables include China and Russia). Although not specifically focused on aggression, "The treaty calls for sales to be evaluated on whether the weapons will be used to break humanitarian law, foment genocide or war crimes, abet terrorism or organized crime or slaughter women and children." However, critics point out loopholes: "it focuses on sales, for example, and not on all the ways in which conventional arms are transferred, including as gifts, loans, leases and aid." ${ }^{33}$ Expansion of similar restrictions may help make a right against aggression as secure as reasonably possible against violations. However, even if weapons trade to aggressive states is made illegal, it does not mean that such states won't find ways to obtain weapons. Domestically we are not surprised to find that some former convicts possess firearms even though they may not legally do so. Of course this is not a reason to allow outlaws (domestically or internationally) to legally and easily obtain weapons.

Another option is for a state to punish leaders who give an order to participate in an aggressive war or the staff that aid them. This might provide some deterrent value, but it would likely be reduced by the possibility (at least in the United States) of a "Presidential Pardon" removing the teeth behind such legislation. If leaders doubt the likelihood of punishment, then the deterrent effect will lessen. Of course, even if the deterrent effect is reduced, retributive justice could still justify punishment. However, it would not be for the

\footnotetext{
${ }^{33}$ Neil MacFarquhar, "U.N. Treaty Is First Aimed at Regulating Global Arms Sales." The New York Times. April 2, 2013.
} 
reason of reasonably securing a right against aggression. Also, a superlative of SCO is that it deters an order to participate in an aggressive war and, if such an order is given, reduces the likelihood of compliance. Punishing leaders can at best merely deter the order. Despite this, it is a great avenue for further study.

Internationally, there is some precedence for bringing leaders to trial for the crime of aggression, however as I have noted, the ICC does not yet have this power. Furthermore, the international political will may neither exist to give the ICC this power nor possess the ability to execute it. It is one thing to add aggression (in addition to war crimes) to the list of charges against the leaders of a state defeated in war; it is another thing to charge the sitting leader of a powerful state with aggression and attempt to bring him to trial. However, even if prosecution would be inconsistent, more formal international recognition of such a crime still could have some deterrence benefit even if only in the court of public opinion. This too is a possibility for further study.

Another option may be for a state to continue or institute a draft. There are two main ways to conceive of this option. The first conception is that a state has provisions for a draft to sustain a war (the status quo of the United States) and the other conception is that a state requires universal conscription. In a state that primarily relies on volunteers, but could implement a sustainment draft, there would be very little benefit towards preventing an unjust war. A war could be initiated, and only if the currently available members were not enough would a draft be needed.

However, for an unjust war that lasts many years, the draft may help end the war sooner. As noted earlier, Cheyney Ryan shared that the resistance of soldiers helped end the 
Vietnam War. ${ }^{34}$ I assume most of these resisters were draftees. This seems a fairly safe assumption as someone who did not want to fight in Vietnam would not volunteer. This is different from the case of SCO, in that SCO would likely be used by someone who volunteered prior to the start of a war. However, it is possible that someone who volunteered to fight after a war had begun could later determine that the war was aggressive.

On the other hand, without a sustainment draft, there may not be enough volunteers to continue fighting, or the state may have to increase incentives for volunteers, thus increasing the cost of the war. Although a draft would increase the political diversity of combatants, unless SCO was also implemented, only universal conscientious objectors would be excused. SCO combined with a draft could increase the number of objectors. However, a draft also increases the number available to fight. Strictly regarding the effect on ending an aggressive war, it is hard determine the impact of a draft. Regardless, it may be necessary to keep a potential draft in place to bolster forces during a defensive war.

A second option is universal conscription. Unlike a draft implemented after a war has started, this option appears to have the potential to prevent aggressive wars. With universal conscription, a state is more likely to have a representative sample of the population in the military. This representative sample is more likely to contain members who would object to a war.

However, there are two caveats. First, without a legal right to SCO, there is limited potential for those members to act on their beliefs. This option would be most effective in combination with SCO. Second, with universal conscription not everyone would be needed to

\footnotetext{
${ }^{34}$ Ryan, “Democratic Duty," 12.
} 
serve past their initial commitment (and it would be extremely expensive to do so). Unless a random selection system is used to determine who becomes a career soldier, the decision to stay past one's initial commitment could become analogous to volunteering in a state without universal conscription. Those that self-select for continued service are likely to be similar to the ones who would have initially volunteered if there was not universal conscription. In the event that an ongoing war requires the call-up of previously trained conscripts, the situation would not be all that different from a sustainment draft discussed above except that the conscripts would already be trained. The marginal gain could occur for those who are serving their initial commitment who otherwise would not have joined without universal conscription. However, these would likely be very junior personnel who, if they did object, could be more easily replaced than their superiors.

This small gain towards stopping an aggressive war would need to be balanced with the drawbacks of universal conscription. Briefly, some drawbacks are the doubts about the ability of conscripted force to fight as effectively as volunteers and the huge cost to train a large percentage of the population. Universal conscription may slightly bolster the effects of SCO, but it is not likely to be a good substitute. For either type of draft, the greater impact would be as combined with SCO, not as an alternative to SCO. I will leave a draft open as an area for further study.

\section{Transition to Just War Theory and Cascading Effects}

State laws allowing SCO and international law requiring states to allow SCO would make a state right against aggression more reasonably secure against violations. However, what can motivate combatants to exercise this allowance? A duty to object could supply this motivation 
and would thus be more effective at preventing aggression compared with a mere allowance. However, I have just shown the concerns with either state or international law requiring such a duty. This leaves open the possibility of a moral duty to object, but moral duties are not the type of thing that can be assigned as a part of a state's duty of institutional design. States do not declare moral duties. Furthermore, just war theory is not an institution.

Fortunately, there is another way to justify a moral duty to SCO that does not involve claiming just war theory is an institution nor that requires bottom-up arguments. In short, the duties to avoid and protect required by just war theory need to be expanded.

Shue would not assign solely a correlative negative or positive duty to a seemingly negative or positive right. I expand on this idea by arguing that we should also not try to simply assign a correlative individual or state duty to every individual or state right. An individual right can be violated by other individuals, but also by a state. If we assign duties to avoid to only one party, we will be ignoring a large opportunity for violations. For example, a state that prohibits kidnappings and assaults by individuals, but, that itself conducts arbitrary arrests and torture, violates its citizens' rights to security. Similarly, if a state is to have rights, duties to avoid must be assigned not just to other states, but also to individuals and any other entity capable of violating the right.

Discussing an individual right to security, Shue himself argues that duties to avoid fall to "individuals, organizations, and governments." ${ }^{35}$ It seems clear that the same entities can also violate state rights. As previously mentioned, when allocating duties, Shue would remind us to "look at what it actually takes to enable people to be secure against standard, predictable

\footnotetext{
${ }^{35}$ Shue, Basic Rights, 60.
} 
threats to their rights - focus on the duties required to implement the right. ${ }^{36}$ In this manner, just war theory currently fails to fully uphold state rights. If a state right against aggression is to be as secure as reasonably possible against violations, just war theory should include a moral duty for combatants to avoid aggression. ${ }^{37}$

Of course a little more needs to be said relating a duty to avoid aggression with a duty to object. As previously mentioned, in addition to objecting, there are of course other ways to not participate (feigning participation, desertion, surrender, self-injury, and suicide). It seems obvious that SCO is a more practical way to fulfill a duty not to participate in an unjust war as it avoids deception, slyly backing out of promises, the potential for injury, or direct injury.

More importantly though, we should keep in mind why this duty to avoid exists. Although desertion and the other ways to avoid participating may prevent a person from committing aggression, they do nothing to prevent others from committing aggression. Desertion announces that one does not want to participate, but does not provide a why. Feigning participation causes others to believe that one supports the aggressive war. SCO, on the other hand tells others why one is not participating and sets an example for why they also should not participate. As previously mentioned, SCO makes it much more difficult for a state to commit aggression. In that way, it enforces a state duty to avoid aggression. In that SCO encourages others to not participate, it also enforces an individual duty to avoid aggression. SCO fulfills a Type II- 1 duty to protect by enforcing a duty to avoid in addition to fulfilling a Type I duty to avoid aggression.

\footnotetext{
${ }^{36}$ Shue, "Afterword," 160.

${ }^{37}$ Although unrelated to my project, by similar logic, groups should also have a duty to avoid committing aggression.
} 
If just war theory requires SCO in order to fulfill a Type I duty to avoid and a Type II-1

duty to protect, it will have cascading effects on the duties I have analyzed so far. Because of a duty to avoid aggression, a duty to follow orders to fight would now be overridden by a duty to not participate in aggression. Obedience must now be considered merely a prima facie duty which can conflict with a duty to not participate in aggression. ${ }^{38}$ An order to fight still has moral weight, but it is not an absolute duty, as the duty to not participate in aggression is weightier. I will not investigate the issue of whether the duty to avoid aggression is itself absolute, nor consider what may override it.

Since combatants have a duty to avoid participating in aggression, combatants would also have a duty to avoid killing combatants and non-combatants as an aggressor. This duty will require that just war theory deny both the base and expanded versions of MEC; if combatants are obligated to object to unjust war efforts, this requirement denies that unjust combatants have the privilege to fight and that they can fight blamelessly.

Ultimately, the source of denying MEC is the logical incompatibility of unjust combatants possessing an equal right to kill with a duty to not participate in aggression or kill as an aggressor. If there is a duty to avoid aggression, then MEC cannot stand. However, as an added benefit, denying MEC contributes to making a right against aggression as secure as reasonably possible against violations in that denying MEC revives a disincentive for

\footnotetext{
${ }^{38}$ Some could argue that according to the prevailing view, a duty to follow orders to fight is already merely a prima facie duty. The reasoning is that the prevailing view only states that a combatant is not blameworthy for participating in an unjust war and that a combatant could be praiseworthy for objecting to such participation. However, the prevailing view does not explicitly confront a combatant with this choice, nor does it require the supporting institutions (such as a legal allowance) that would enable a combatant to more freely choose.
} 
combatants to violate a Type-I duty to avoid committing aggression. That disincentive is the moral guilt that unjust combatants may otherwise feel. Wertheimer states:

People everywhere are understandably receptive to the idea that, as long as they follow their leader, the blood they help shed in uniform will not stain themselves. What could be more comforting than a conviction relieving you of any anxieties about your culpability for complicity in killing in a morally dubious enterprise ${ }^{39}$

Denying MEC removes that comforting conviction. If just war theory were to incorrectly leave MEC in place, it would discourage combatants from upholding their now enumerated duty to avoid aggression and to avoid killing as an aggressor.

The value of these changes to avoiding aggression is that the combination of denying MEC and requiring SCO should make it much harder for governments to instigate and execute an aggressive war. Subjectively, the value of these changes is that combatants are morally empowered. By denying MEC, individual combatants would no longer be persuaded to ignore doubts about their state's justification for war. Combatants should take those doubts seriously; the now enumerated moral duty to object would better inspire, and the now enumerated legal allowance of SCO would better enable combatants to respond to those doubts.

The upshot is that trying to reconcile the prevailing view of just war theory with Shue's tripartite framework forces changes in just war theory, substantially modifying it by requiring SCO, assigning combatants a duty to avoid aggression, as well as a duty to avoiding killing as an aggressor, making a duty to follow orders to fight merely prima facie, and denying all versions of MEC. These are in addition to the legal changes that would be required. Below is a chart showing the modifications required when SCO is required by just war theory.

\footnotetext{
${ }^{39}$ Wertheimer, "Reconnoitering," 64.
} 


\begin{tabular}{|l|c|c|c|}
\hline Duty Bearer & Right Holder & Type I Duty to Avoid & Modification \\
\hline Combatants & Other States & None exists & Avoid Aggression \\
\hline Combatants & Other Combatants & Avoid killing unnecessarily, or disproportionately & Add: Avoid killing as an aggressor \\
\hline Combatants & All Non-Combatants & Avoid killing directly, intentionally, or disproportionately & Add: Avoid killing as an aggressor \\
\hline & & Type II-1 Duty to Protect By Enforcing a Duty to Avoid & \\
\hline Combatants & Other States & None exists & Object to participating in a unjust war \\
\hline
\end{tabular}

\section{Bottom-Up Arguments Revisited}

These are very similar to the changes that would be required by bottom-up arguments for SCO or against MEC. However, I have not had to utilize such arguments. By utilizing topdown arguments to protect state rights, I have opened up a new front in the debate. Many of the bottom-up arguments are solid, but change has been slow. I would like to compare the conclusions of my top-down approach with those of bottom-up approaches. I will not compare it with enabling arguments since by definition enabling arguments do not address a moral right or duty of SCO. Recall that I previously referenced four general types of bottom-up arguments. Two begin with some aspect of MEC and then argue for SCO. The other two argue for SCO more directly. The first argument is that combatants have a duty to avoid killing noncombatants as an aggressor. The second is that combatants have a duty to avoid killing combatants as an aggressor. The third bottom-up argument argues directly for a moral duty to SCO, and the fourth argues directly for a moral right to SCO.

The first argument is that a combatant has a duty to not kill non-combatants as an aggressor. Since it is nearly impossible for a war to be fought without endangering noncombatants, this now implies that a combatant has a duty to avoid participating in an aggressive war, except perhaps in anomalous wars that do not endanger non-combatants. It seems a plausible next step that if there is a duty to avoid participating in an aggressive war, then there is duty for combatants to selectively conscientiously object. As previously 
mentioned, there are other ways to comply with a duty to avoid participating in aggression such as feigning participation, desertion, surrender, self-injury, or suicide. Yet all these methods have risks and costs that are probably unreasonable. Also, one thing this bottom-up argument does not address directly is whether it is permissible for unjust combatants to kill just combatants. This means in some rare cases in which only combatants are at risk, it may be permissible for combatants to participate in an aggressive war. In that way, it is less powerful than my top-down argument. Also, this argument does not address state laws. A state could still deny an allowance for SCO, thus placing a combatant in a situation where their legal duties and moral duties conflict and the legal duties are backed by the threat of a strong punishment.

The second argument is that a combatant has a duty to not kill combatants who are fighting for a just side. This also implies that a combatant has a duty to avoid participating in an aggressive war, and the same argument for SCO applies as above. This bottom-up argument does not directly address the status of aggressors killing non-combatants, but if aggressors are not permitted to directly kill combatants, it is very improbable that aggressors will indirectly kill non-combatants. This bottom-up argument has similar effects to my top-down argument, except that just as above, it does not address whether a state should allow SCO.

The third general type of bottom-up argument is one that argues directly for SCO as a duty without first addressing MEC. Instead of a denial of MEC leading to an affirmation of SCO, in this case, an affirmation of SCO leads to a denial of MEC. If unjust combatants have a duty to not fight, then they cannot be the moral equals of just combatants who have permission to fight. Also if unjust combatants have a duty not to fight, then they would be blameworthy for 
fighting. The third general type of bottom-up argument has a similar effect to the top-down method except that it too fails to address a state allowance for SCO.

The fourth general type of bottom-up argument only argues for merely a moral permission to object. Although, this is incompatible with extreme MEC, neither the base nor the expanded forms of MEC are necessarily denied. A moral permission to object implies that a combatant cannot be blameworthy (and may be praiseworthy) for refusing to fight in an unjust war but does not necessarily deny he could possess as equal right to kill or would be blameless for participating. The fourth general type of bottom-up argument differs from my top-down method in that neither does it deny base and expanded MEC nor does it address state laws regarding SCO.

\section{Advantages of my Method}

Common sense already tells us that we should take action to make it more difficult to do undesirable things such as start aggressive wars. Do we really need Shue's theory to tell us that we should make it harder to start an aggressive war? If so what does it add? First, Shue tells us it is a duty to protect rights, not just something desirable. Jus ad bellum only tells a state what it must do to avoid violating rights; it does not tell a state or individuals that it/they must take positive action to prevent those violations. Shue intends for us to take protective duties more seriously. I have focused on preventing aggressive war, but an area for further study is to consider discouraging violating jus in bello. Yes, many states have preventive efforts, but Shue reminds us that these are not luxuries, but rather necessities.

Throughout this discussion, a reoccurring advantage of my method is that it is more robust by addressing both legal and moral SCO. Certainly, enabling arguments could be added 
to any bottom-up argument so that it can also address a legal allowance of SCO, but this would, at best, only make the second and third type of bottom-up argument equal to the power of my top-down argument. ${ }^{40}$ Also, as we will see shortly, the top-down method offers an additional advantage in addressing a common objection to SCO. That objection is that SCO would make it difficult for a state to defend itself (which is a state duty in support of a state right against aggression). By focusing on state rights, I can dismiss that counter argument by showing what state rights (and related duties) entail upon deeper investigation. Protecting rights is not a new concept, but states have focused on Type II-1 protection of their own rights at the expense of Type II-2 protection of the rights of all. Shue reminds us that the pursuit of one state's security must be tempered by the rights of other states. Nonetheless, even though none of the bottomup arguments morally empower combatants better than my top-down method does, accepting any bottom-up argument is an improvement to the status quo. In the next chapter, I will address objections to SCO and offer further refinements.

\footnotetext{
${ }^{40}$ As previously mentioned, McMahan does consider "institutional accommodations" to a moral duty to object. However, the reason for these accommodations is to prevent treating combatants unjustly not to prevent aggressive wars (Jeff McMahan, Killing, 7 \& 97).
} 


\section{Chapter Five: Responding to Objections and Further Refinements}

\section{Does SCO Endanger State Self-Defense?}

Although I have made the positive case for how SCO will help make the right against aggression as secure as reasonably possible against violation, I have yet to respond to objections to SCO. The largest concern is that empowering combatants will endanger state rights by making a state less secure. How could SCO endanger state rights? The primary argument is that an allowance for SCO might make a state unable to field an effective military for self-defense. In the event of an actual attack, the military would be unable to protect a state's rights. Also, an ineffective military would reduce the deterrent effect of a state's military and encourage other states to commit aggression in response to perceived weakness. A second concern is that SCO would make it more difficult for a state to commit unjust actions that would bolster security.

Just war theory requiring SCO and a state allowing SCO might weaken a state's ability to defend itself against aggression. The concern is that even if confronted with a just defensive war, a state might have too many combatants claiming the war is unjust and opting not to fight, or, even if there are sufficient numbers, the army may lack discipline and cohesion. ${ }^{1}$ Those objecting could be mistaken (due to errors in reasoning, false or incomplete data, motivated beliefs, rationalizations, etc.) or could be making a deliberate attempt to avoid fighting by abusing the policy of SCO. I have two main arguments against this concern. The first is that a sorting process (to be detailed later in the chapter) could be used to limit insincere and

\footnotetext{
${ }^{1}$ McMahan, Killing, 99.
} 
mistaken objections. Paul Robinson sees this need, stating, "Consideration should be given to creating a mechanism which can differentiate between sincere and insincere objectors (perhaps in the form of selective conscientious panels similar to those faced by general conscientious objectors)." ${ }^{2}$ The second is that human psychology suggests that insincere or mistaken objections are not very likely.

I will frequently reference the fact that "there is a strong bias toward believing that a war fought by one's own state must be just." ${ }^{3}$ In addition to this bias, McMahan doubts that not enough combatants would answer their state's call, stating, "When people have been threatened by unjust aggression by a foreign power, they have almost always been willing to fight." ${ }^{4}$ As an example he gives the Israeli Defense Force (IDF) which, although not legally allowing it, has a history of much selective conscientious objection. He states, "No one doubts that everyone in the IDF would fight with the utmost cohesion and determination in a just war of national defense." ${ }^{5}$ Claiming "everyone" would fight may be an overstatement, but it need not diminish his point. Not all states have the patriotic fervor that Israel does, or the difficult history that has likely cemented such fervor. However, it stands to reason that most citizens would be willing to defend their homeland, if their homeland is a state worth defending.

If there was a case of combatants unwilling to defend their homeland, the cause is not likely to be SCO, but rather the fact that the citizens do not think their state is worth defending. The case of a state whose citizens do not deem it worthy of defense speaks loudly to the

\footnotetext{
${ }^{2}$ Robinson, "Integrity," 46.

3 Jeff McMahan, Foreword to When Soldiers Say No, edited by Andrea Ellner, Paul Robinson, and David Whetham, (Burlington: Ashgate, 2014), XV. See also, McMahan, Killing, 108 \& 144.

${ }^{4}$ McMahan, Killing, 99.

5 lbid., 75-76 \& 99.
} 
perceived legitimacy of such a state. Of course, a state perceived to be so illegitimate as to be not worth defending is likely a state that fails to protect rights and unlikely one that allows SCO. Such a state is more likely to resort to harsh measures to force its citizens to fight.

Instead of combatants merely getting their judgment wrong, another possibility is that an enemy could trick just combatants into believing that their state's war is aggressive, and thus into mistakenly objecting. Reimagining a blatant aggression such as the Nazi invasion of Poland, it is possible that the Germans could have fabricated a story in which Poland was preparing to execute a devastating surprise attack, but intelligence operatives were able to discover the plan and launch a preemptive strike. They could publicize to Polish combatants that although German actions appear aggressive, it is actually Poland who is the would-beaggressor. Would soldiers of the victim state believe this? It is not likely.

Of course a state's reputation may be an important factor in what one's own soldiers and neighboring states believe. On one hand, a state without a reputation for aggression, and that has taken steps to reduce aggression (such as SCO), is more likely to be worthy of the trust of its combatants and the world at large. On the other hand, a state that is routinely aggressive and has been untrustworthy in the past will be more likely to be doubted. ${ }^{6}$ Combatants will have to weigh the evidence, but if properly educated (details to be given later) they are less likely to be duped by an enemy. The way combatants are more likely to be duped is falsely believing that their own state's war is not aggressive. A system to educate combatants regarding just war theory will help prevent this, as well as the previously mentioned possibility of punishing state leaders who deceive their citizens in starting an aggressive war.

\footnotetext{
${ }^{6}$ Ibid., Killing, 152.
} 
Related to this objection is the concern that doubt about a state's ability to field an army could make a state appear weak and reduce the deterrent value of having a military. I concede that a perception of a state as weak may encourage aggression, but as just discussed, so can a perception of a state as aggressive. If there is to be a proper balance, it will likely be for a state to appear tough in response to aggression but to not appear otherwise threatening. A legal allowance to object, along with other demonstrations of a commitment to avoiding aggression, should help achieve this balance and make neighbors less worried that a state will abuse its military power.

A second concern is that SCO would prevent a state from committing unjust actions that would increase security. One such possibility may be a war in which there is a just cause to fight, but in which the overall effects of fighting would be disproportionate. ${ }^{7}$ Recall that proportionality is one of the traditional principles of jus ad bellum. Due to the lack of proportionality, a state permitting SCO may find its combatants unwilling to fight in what would be an unjust, but not aggressive, war. My first response is that so far I have built my theory of SCO on objecting to aggressive wars, not wars that are unjust for other reasons. If the reasons for objecting are expanded, this could become a concern, but it is not one yet.

Even if I expand the reasons for objecting to include all of the jus ad bellum criteria, it is by definition a benefit to humankind if a disproportionate war is not fought. Of course it is possible that the war would be proportionate, but enough combatants falsely think it is not. Again, however, this is unlikely due to the previously mentioned bias that combatants are more likely to believe their own state's wars are just rather than the opposite. Finally, even if in some

\footnotetext{
${ }^{7}$ Yitzhak Benbaji, "The Moral Power of Soldiers to Undertake the Duty of Obedience," Ethics, 122:1 (2011): 55-56; Jeff McMahan. “Obedience, Desert, and Proportionality in War: A Response," Ethics, 122:1 (2011): 146.
} 
cases aggression is not resisted due to a mistaken belief that the war is disproportionate, this is a reasonable side-effect of reducing aggressive wars. In a very literal way, this is equivalent to the domestic case of designing a legal system that occasionally allows the guilty to go unpunished rather than punish the innocent.

A further example of an unjust action that might increase security would be an aggressive war that might make a state more secure. Consider for example the Soviet Union's acquisition of satellite states to form a buffer zone during the Cold War. Yes, it made Russia more secure from external aggression, but it did so by committing aggression against the likes of Hungary and Czechoslovakia. ${ }^{8}$ SCO could prevent occurrences like this (although it is not likely that a totalitarian state will legalize SCO).

I concede that it initially appears that a state may be better able to protect itself if it is not limited by SCO. In a similar way, it initially appears that a citizen may be better able to protect their person and possessions by carrying a handgun and following a "shoot first ask questions later" policy. However, in the long term such aggressive behavior is more likely to result in general mistrust and both accidental and intentional violations of rights. The supposed benefit is probably illusory. Likewise, a state with a reputation for aggression will breed future enemies. Allowing SCO bolsters a state's long term interests in regards to self-protection. From a more theoretical perspective, we should turn to the question of why protection is required in the first place. As Shue's theory demonstrates, duties to protect exist to promote the fulfillment of duties to avoid. However, the overzealous pursuit of state "protection" increases the likelihood of violating duties to avoid owed to another state (such as by acquiring

${ }^{8}$ Orend, Morality, 61. 
satellite states). As duties to avoid are in support of basics rights held by all, it is inconsistent to violate duties to avoid (towards one group) in the name of honoring duties to protect (for another group). Shue addresses this issue stating, "The proposed general principle that one government may contribute to the deprivation of the rights of people in another country whenever that would be useful to the protection of the basic rights of its own people is a recipe for a war of all governments against all people except their own." ${ }^{9}$ A strength of the top-down method is that it forces us to evaluate exactly why we are trying to protect our own state's security in the first place, and to think outside of narrow self-interest when evaluating how to fulfill our own state's security.

\section{Combatant Education}

The next concern is combatant education and the effectiveness of a duty to object. If a duty to object is to be effective at preventing aggressive wars, then combatants will need to be able to reliably judge a war's justice. McMahan acknowledges this concern saying, "as a practical matter, much depends on the reliability of soldiers' judgments, on the probability that they will correctly judge wars to be just or unjust." ${ }^{10}$ What would soldiers have to know to reliably fulfill a duty to object? In order to make such a judgment responsibly and well, combatants will need theoretical knowledge of just war theory, knowledge of the specific cases, and practice at applying theory to actual cases. Later in this chapter, I will discuss what standard of judgment should be used when evaluating combatants' objections.

Currently combatants are required to object to orders to violate jus in bello (such as an order to deliberately kill civilians or prisoners). However such situations are often less complex,

\footnotetext{
${ }^{9}$ Shue, Basic Rights, $1^{\text {st }}$ ed, 166.

${ }^{10}$ McMahan. "Obedience," 144.
} 
and the required information is more likely available by near-instantaneous first-hand observation. For example, it does not require an intricate understanding of just war theory to understand that deliberately killing a baby would be wrong or to evaluate whether such a child is a threat. Even the more difficult cases, where it is more difficult to determine if someone presents a threat, are much less complex than evaluating whether a state has a just cause for resorting to war.

It appears that additional training would be required to enable the majority of combatants to even begin to properly analyze jus ad bellum. This training will cause an increase in the time and cost of training combatants. States may balk at this, but it is an instance of the general principle that protecting rights is expensive. ${ }^{11}$ Offering this training will help a state fulfill its Type II-2 duty to make a right against aggression as secure as reasonably possible against violation. Additionally, the training in question could be a part of robust training in just war theory. This would help protect against jus in bello violations, a Type II-2 duty of both states and combatants. The impact of the training is that it will help a state fulfill Type I duties to avoid aggression and avoid violating jus in bello. It will also help a combatant fulfill Type I duties to not participate in aggression and avoid violating jus in bello.

What should just war theory education and training look like? It should begin with secondary education. An education system that includes just war reasoning should be required by institutional design, as an informed citizenry will also make it much less likely that a country will participate in an aggressive war or tolerate violations of jus in bello. This would also serve as the first exposure to just war theory for potential future combatants. Further training in just

\footnotetext{
${ }^{11}$ This is the general thesis of The Cost of Rights, by Stephen Holmes and Cass Sunstein (New York: W. W. Norton, 1999).
} 
war theory would come as a part of combatants' military training. Currently some state governments train (and all should train) combatants about complying with jus in bello. Jus ad bellum training should be added to this. Another benefit of adding jus ad bellum training is that understanding the bigger picture of just war theory should help provide more motivation for compliance with jus in bello which states also have a duty of institutional design to achieve. For example, understanding that a state is going to war to protect human rights should motivate compliance with jus in bello in order to not violate rights. Orend references the civil wars in the former Yugoslavia as an example that "dark motivations produce distinctive and noticeable results, such as torture, massacres, mass rapes, and large-scale displacements." ${ }^{12}$ Combatants who go to war for reasons other than vindicating rights are more likely to succumb to these and similar temptations.

Jus in bello should not be taught as merely a series of legal guidelines divorced from the rest of morality. Also, jus in bello can have a large impact on jus post bellum, and combatants should be aware of the relationship. ${ }^{13}$ Consider the difficulties in convincing a conquered state that your state aims to help them rebuild in order to fulfill their rights, when during the war your state ignored their rights. It would be ironic to build a school for the surviving peers of children that were killed when combatants failed to observe jus in bello requirements. Additionally, it would be ideal if most combatants comply with jus in bello not just because they are legally liable by international law (and quite often state law), but because they recognize it as a moral duty.

\footnotetext{
12 Orend, Morality, 47-48.

${ }^{13}$ Ibid., 195 \& 204.
} 
I am not suggesting that all combatants receive even near the equivalent of a semesterlong class on just war theory; probably 10-15 hours of instruction should be sufficient. By way of comparison, as a part of a semester-long ethics class at the United States Air Force Academy, I only spend 10 classroom hours (reading outside of class is also required) specifically on just war theory. This instruction should cover the theoretical aspects of just war theory, but of course learning the details of any specific war (or potential war) will be each combatant's responsibility as the situation develops. I do not wish to give too fine-grained an analysis as to what this reasonably requires, but combatants should be skeptical of what they read and hear, and should attempt to confirm information with multiple sources. A portion of the required training can cover how to go about this. By training all combatants to think critically about just war theory, specifically jus ad bellum, a duty to object can be complied with well and responsibly. However, can we really trust states to provide this education?

\section{Can States Be Trusted to Properly Educate Combatants?}

A general suspicion regarding combatant education asks: Can a state that can't be trusted to avoid aggression really be trusted to provide good education for detecting and rejecting aggression? There are at least three ways to look at this question. The first perspective asks: Can a state that routinely and flagrantly disrespects rights be trusted to take steps to protect rights? The answer is probably not. If a state does not care about rights, why would it consider installing safeguards to help uphold rights?

As evidence of this unlikelihood, Carl Ficarrotta's recent discussion of guidelines for implementing SCO began with the assumption that any state considering implementing SCO would be one that does not conscript, or at least allows exceptions for universal conscientious 
objectors if conscripted, and would be one that expects its soldiers to obey jus in bello rules and punishes jus in bello violations. ${ }^{14}$ Ficarrotta believes this a reasonable assumption, since a state that does otherwise "would be a strange one, a country experiencing moral development in rather an odd order."15 These assumptions suggest a connection between respect for rights in various forms, as well as a pattern of moral development. ${ }^{16}$ Unfortunately, prescribing more duties to states that flagrantly disregard rights and the duties required to fulfill them will probably not make much difference. Fortunately, not all states are like this.

States that generally do well at respecting rights still sometimes fail to avoid aggression. At the risk of personifying states, another perspective is that of akrasia. A state that generally wants to avoid aggression will realize that sometimes it may be very difficult. Proper institutional design can help prevent such states from acting against their better judgment. From this perspective, the answer to the opening question is, "Yes." States that sometimes fail to avoid aggression but that generally respect rights might be trusted to provide good education for detecting and rejecting aggression.

Although still acknowledging akrasia, Shue's perspective considers the question from the opposite direction. A state that can be trusted to provide good education for detecting and rejecting aggression is a state that will be less likely to engage in an aggressive war. A state attempting to fulfill Type I duties will be more likely to achieve this due to the effects of fulfilling Type II duties. As a domestic analogy, consider a person on a diet who has a weakness for candy. He will be much more likely to avoid overindulgence in candy if he takes the

\footnotetext{
${ }^{14} \mathrm{~J}$. Carl Ficarrotta, "Selective Conscientious Objection: Some Guidelines for Implementation," in When Soldiers Say No (Burlington: Ashgate, 2014), 197-198.

${ }^{15}$ Ibid., 198.

${ }^{16}$ Ibid.
} 
protective step to reduce the amount of candy in his home. By design, Type II duties (to protect) make it easier to not violate Type I duties (to avoid).

\section{Guidance Based on Prima Facie Duties}

In addition to education in how to judge whether a war is aggressive, combatants need guidance as to what to consider when contemplating SCO and how they should act when objecting. Not only will this increase the effectiveness of SCO, but it will also decrease some of risks associated with SCO. First, combatants need to determine if the war they are ordered to participate in is an aggressive war. Combatants should investigate whether their state's claims and the evidence used to support those claims are credible. Recall, I am deriving a combatant's duty/allowance to object from a state's duty to discourage aggression. As such, I only consider SCO for wars that are aggressive (i.e. lack a just cause), not wars that are unjust for failing other jus ad bellum criteria.

If a combatant determines a war is aggressive, then they need guidance to help address if and how to object. I believe that previously discussed just war criteria rebranded as override criteria, mitigating criteria, and resolution criteria can provide this guidance. It should be noted that, in line with my overall thesis, I have considered SCO according to my top-down method and within a system that grants combatants a legal allowance of SCO. However, I believe that the same criteria should apply for a combatant considering SCO in a system that does not provide such an allowance. I will specify when I am diverging from the above assumption. Here is a discussion of what a combatant should consider:

Just Cause: Is there a good reason to SCO? Ultimately the reason should be that the ordered war is aggressive. The objector needs to show that there is another prima facie duty 
(to avoid participating in an aggressive war) that will trump the prima facie duty to follow orders to fight. More expansively, the just cause for SCO could be that jus ad bellum is not met, although so far I am restricting the case to wars that are unjust because they are aggressive, not wars that are unjust for failing other jus ad bellum criteria.

Right Intention: Is the combatant motivated by a moral reason to object? There is potential for abuse of an allowance of SCO, and both the objector and any system evaluating SCO claims should determine whether the duty to avoid participating in an aggressive war is really what is motivating the SCO. For example, a combatant may prefer to remain stateside with family, or to focus on other endeavors instead of deploying for war. Cowardice could also be cloaked behind SCO. Now of course there is the possibility of multiple motives being present. The presence of other motives may raise suspicion, but a combatant who is afraid to fight or does not want to deploy can also sincerely believe a war is unjust regardless of other motives. I will parallel Walzer's and Orend's method of handling this overdetermination; when considering jus ad bellum they require a state to have a moral motive but concede that other motivations may be present. ${ }^{17}$ To help demonstrate the sincerity animating the moral motive, a combatant can volunteer to fight in a different theater of war or volunteer for a different assignment in hazardous or austere conditions. James Childress shares my belief that alternative service helps demonstrate an objector's sincerity. ${ }^{18}$ Quite frequently this alternative service is conceived outside of the military, though it need not always be. In the Second Gulf War, US Army Lieutenant Ehren Watada refused to deploy to Iraq as he believed it was an aggressive war, but he volunteered to fight in Afghanistan which he did not believe was

\footnotetext{
${ }^{17}$ Walzer, Wars, XVIII-XIX, and Orend, War, 46-47.

${ }^{18}$ Childress, Moral Responsibility, 217.
} 
aggressive. ${ }^{19}$ There is precedence for some universal conscientious objectors to serve in noncombat positions. Analogously, those who selectively object could demonstrate sincerity by volunteering to serve in parts of the war minimally related to the unjust war, such as in a medical capacity.

A combatant having to object should feel regret that it ultimately had to come to this and that the system nearly failed. This is perhaps similar to how some say a combatant should feel about having to kill. Karl Marlantes writes, "The ideal response to killing in war should be one similar to a mercy killing, sadness mingled with respect." ${ }^{20}$ He later contrasts "going on a crusade to eliminate evil" with what should be a more proper attitude, "Reluctantly and sadly eliminating evil because it is a loathsome task that a conscientious person sometimes has to do." ${ }^{21}$ James Childress states that "regret" is an appropriate response to having to fight a just war. ${ }^{22}$ Just as a state with right intent should ensure the war is a last resort and regret having to fight, combatants with right intent should ensure that SCO is a last resort needed to uphold rights and not just an attempt to have a moment in the spotlight or "thumb their nose at civilian authorities, perhaps holding out for more pay, or even making a play for political power." ${ }^{23}$

Public Declaration: ${ }^{24}$ In war, the public declaration is meant to notify the other side and give them one last chance to capitulate. It should leave no doubt about the relationship between the two states. It also notifies one's own citizens whom the government represents.

${ }^{19}$ William Felice, How Do I Save My Honor? (Lanham: Rowman and Littlefield Publishers, 2009), 126-129.

${ }^{20}$ Karl Marlantes, "What it is Like to Go to War" (New York: Atlantic Monthly Press, 2011), 42.

${ }^{21}$ Marlantes, What it is Like, 59

${ }^{22}$ Childress, "Just-War Theories," 432.

${ }^{23}$ Orend, War, 136.

${ }^{24}$ Orend combines public declaration and proper authority, but, I have elected to discuss them separately (War, 50). 
How does this apply to SCO? I think the relevant value is that just as with starting a war, SCO should not occur in secret. A combatant needs to give a formal and definitive declaration of one's intent. It need not be done publically in the sense of announcing to the media, but it needs to be public in the sense that the state (via the command structure) has no doubt about the combatant's intent to not follow an order to fight in an unjust war. The state should be required to release information regarding SCO to the public. If one wishes to be an example for justice and a role model to others, publicity would be helpful. However, this need not be sought, and seeking it may discredit a combatant's intention. A free press will likely work hard to report SCO. This coverage will help encourage others to object and discourage a state from starting an aggressive war, which is after all the intent behind legally allowing and morally requiring SCO. Although a literal interpretation of public declaration may appear to conflict with SCO, the spirit of public declaration is achievable.

Proper Authority: Has the combatant in question been ordered to deploy for an aggressive war or otherwise take action closely connected to supporting such a war? Combatants have a duty to avoid participating in an aggressive war, but not a duty to protest a war in which they have not been asked to participate. SCO is not meant to be used as a tactic (such as a sit-in or strike) to protest policies but instead a tool to carry out moral duties. Consider a fuel technician who refuels airplanes at a stateside base that is not sending planes into the combat theater. He would not really be contributing to the unjust war. He would perform the same job in times of peace. Such a combatant would not be a candidate to SCO. Of course, he could later be ordered to deploy and thus become a candidate. However, he 
should wait until ordered to deploy because objecting prematurely becomes too much like a protest.

Some might say a combatant should have a further duty to protest as a part of a Type II1 duty to protect by enforcing a duty to avoid. Objecting would comply with their Type I duty to avoid and also contribute to a Type II-1 duty. The question is: Would further actions be needed to comply with this Type II-1 duty? Due to the unique role of military members as both citizens and soldiers, Type II-1 duties may differ for combatants compared to other citizens. The reason is due to the danger that protesting would present to civilian-military relations and ultimately, political sovereignty. These concerns, to be discussed in sections on last resort, proportionality, and discrimination, place a limit on the extreme to which a combatant would need to attempt to enforce duties to avoid. I acknowledge the irony of being conservative when it comes to executing a progressive theory. Nonetheless, I am sensitive to the dangers of a military coup and want to show that I am mitigating those dangers so as to lessen a potential argument against SCO.

Last Resort: Have other options been tried? Combatants should let the democratic process work and should not officially declare to their command the intent to object to a war that is still being debated within the government and media or that they have not yet been ordered to fight. Let's consider why last resort matters for SCO. War is a last resort because it is overturning a prima facie duty. That prima facie duty is in place due to the large-scale destruction, the direct killing of combatants, and the indirect killing of non-combatants. SCO is also overturning a prima facie duty, one of obedience to orders to fight. At first glance it may 
seem the negative effects of overturning it are not bad, and we might only focus on the positive effects of not fighting an aggressive war.

However, the prima facie duty to obey orders to fight demonstrates (at least in democratic countries) civilian control of the military. Civilian control of the military, the peaceful post-election exchange of power, and the absence of military coups should not be taken for granted. SCO can threaten the civilian-military relationship and increase the risks of violating those norms which underpin democracy. Objecting too early demonstrates a lack of patience and trust. It is important to show that, despite an allowance of SCO, the military still trusts the system and will not attempt to circumvent civilian control except when absolutely essential. There is certainly a tie between acting as a last resort and having the right intent.

Despite this, if state leadership is aware that many combatants plan to object, this may discourage plans for an aggressive war. This is after all the desired effect of SCO. If military members are too tight-lipped regarding their intended actions, then this effect is reduced. Perhaps anonymous surveys conducted by reputable media outlets would enable the twin goals of informing civilian leadership without appearing that the military is too hasty to act. From this perspective, it may be best to delay these surveys, but I am not about to suggest how the media should operate. Of course if a survey reveals that leaders should not expect much dissent, then they may continue with their plans for an unjust war. It may be better off if the government is in doubt and must tread carefully. This may be another reason for the military to not reveal their intentions too early. However, as things currently stand, states expect obedience, so acting on information that combatants are not likely to object would not be any worse than the status quo. 
Alternatively, the military could conduct surveys to be used as a tool to counsel civilian leaders. For military-run surveys, there could be a planned waiting period to give the political process a chance to work. Redundant internal and external surveys may be a way to demonstrate reliability of results. From a decision-making perspective, what is needed is the aggregate data of what to expect from the military. This can be provided without individual combatants formally declaring their intent. Just as with jus ad bellum, the criterion of "last resort" requires a balance be struck between acting too early and waiting too long. The details are difficult to determine in advance, but an example of a failure would be if on the first day a war is considered, a large number of combatants notify their commanders they are objecting (to a yet-to-be-given order).

Probability of Success: Is the action likely to succeed? This heavily depends on what is meant by success. If by success we mean that a lone individual's SCO will prevent an unjust war, then rarely, if ever, could this element be met. The exception may be for someone extremely high ranking (or in a high office) such as Secretary of State Colin Powell, who by resigning could have gone far towards preventing the Second Gulf War. ${ }^{25}$ Of course, one combatant does not win a war either, so we really should consider the collective effect of many combatants objecting. In that case, then the aggregate effect is more likely to prevent an unjust war, which is in fact the goal of including a duty to SCO as a part of duties to protect.

Even if an objection does not prevent a war from starting, the example it sets may help end the war sooner or prevent future aggressive wars. However, I am hesitant to define probability of success in such a manner that the criterion becomes vacuous. Within jus ad

\footnotetext{
${ }^{25}$ Felice, Honor, 76.
} 
bellum, probability of success is required to prevent futile warfare, bloodshed for no reason. In a state that allows SCO, the danger of objecting, but not preventing, a war is not as extreme. However, in a tyrannical society that summarily executes objectors (an extreme of not allowing $\mathrm{SCO})$, it may be that the objection would accomplish very little towards preventing aggressive war.

Proportionality: Aggressive wars are a terribly bad thing, so in most cases SCO will be proportionate. However, there may be exceptions, so this element should not be entirely ignored. One such item to weigh is the contribution that SCO will have to eroding the civilianmilitary relationship. If a state is teetering on the edge of a coup or civil war, acts of SCO may be enough to complete the descent. Of course a state on the brink should not attempt to gain credibility or popular support by starting needless wars. Such a situation may be an example of when SCO is needed most. As another possibility, imagine a state engaged in a large just war and a smaller unjust war. The concern is that objections to the second may cause backlash and a failure of the country to support the first. A plausible case where this could occur is if the first war is an unpopular but just humanitarian intervention. A plea to values and demonstrating how the first war supports human rights and the second does not may help to achieve the appropriate response of support and non-support for each war respectively, but the failure of such an attempt must be considered when analyzing proportionality.

In a state that does not allow SCO, combatants will also need to consider the effect on their own lives and those of their families. Loss of employment, loss of expected retirement benefits, imprisonment, or (in the extreme) execution will have to be balanced with the overall good. What risks are combatants willing to take to avoid aggressive wars? This highlights the 
importance of a legal allowance to SCO if we expect any but the most morally sensitive combatants to object.

Mitigating Criteria: I previously stated that after determining that a prima facie duty should be overridden one must also apply mitigating criteria. I stand by that, but in the case of SCO, some of the mitigating criteria are primarily applied as part of the original override. Just as with an overridden promise, SCO is not a large act composed of multiple smaller acts. Proportionality and necessity are already accounted for by the override criteria of proportionality and last resort, but discrimination still needs to be applied.

Discrimination: The key here is that a combatant should highlight the fact that they are objecting to an unjust war but not to the government in general. At the extreme, a failure to discriminate could be part of using SCO as a cloak for a military takeover. More likely, a failure to discriminate between the government's policy and the government itself reflects poorly on a combatant's intention and causes one to doubt the sincerity of the professed just cause. Furthermore it could negatively affect proportionality by eroding the civilian-military relationship. As an example of a failure to discriminate, the previously mentioned Lieutenant Ehren Watada stated "I am wholeheartedly opposed to the continued war in Iraq, the deception used to wage the war, and the lawlessness that has pervaded every aspect of our civilian leadership." ${ }^{26}$ The last part of his statement is directed at the government itself and not the order to participate in the war.

Resolution Criteria: Unlike many overrides which place the overriding agent in a unique ongoing status (war, civil emergency), SCO does not. Presumably, combatants could be ordered

\footnotetext{
${ }^{26}$ Ibid., 127-128.
} 
to fight in a just war shortly after an act of SCO, and they would follow orders the same as if the order to fight an aggressive war had never been given. From the state's perspective, an objector volunteering for or accepting another assignment demonstrates a return to the status quo. However, we should also consider the combatant's perspective. Assuming the objection is legitimate, the onus of repairing this damage must come from the state who forced their combatants into such a difficult situation. It is as if the roles are reversed from the scenario of overriding a promise. If combined acts of SCO prevent an aggressive war, perhaps a ceremony thanking the objectors could be in order. The objectors could humbly respond by saluting their civilian leadership, but such a ceremony is only symbolic. The real work must be done by the government demonstrating a commitment to avoiding aggressive wars in the future. Only then will the government regain the trust of its combatants and citizens. In the case where there are many objectors, but the war still goes on, it is likely that there will be lingering tension. Attempts should be made to resolve this tension, but if neither side admits fault, it will be difficult to resolve except through the passage of time.

Combatants need a method to help them consider whether SCO is appropriate. Fortunately, there is a guide to objecting with which a military and a state educated in just war theory should already be familiar. The just war criteria rebranded as override criteria, mitigating criteria, and resolution criteria should be considered prior to a combatant objecting to an aggressive war. The repurposing of this existing tool and education regarding it and just war theory will be mutually reinforcing. 


\section{Secondary SCO}

Although proper education can make SCO effective, I also need to consider fairness. Would a legal allowance of SCO be fair to other combatants who chose not to object? All combatants would have the same moral duty and legal allowance, but it is likely that some will chose to object and others will not. Those left to fight will have to pick up the work the objectors would have done, and face the dangers the objectors would have faced. ${ }^{27}$ Is it fair to impose these costs on a combatant who chooses not to object?

My approach to this question is a proof by cases, and I will attempt to show that in no case is there an increase in risk without the consent of the non-objectors. The best overall result for the non-objectors is that, due to the efforts of objectors, they are able to avoid having to fight in what would otherwise be an aggressive war. The non-objectors would face fewer burdens, less risk of death, and less moral risk due to the allowance of SCO. At the other extreme is the case where the war is obviously non-aggressive and the non-objectors have the full support of all reflective combatants who rightfully conclude it is acceptable to fight. In this last case there may still be some who think the war is moral, but just don't want to be the ones to fight. A sorting process would be in place to prevent these would-be free riders from abusing SCO.

The trickier case occurs in the middle, where there are not enough objectors to cause the government to abandon its efforts at an aggressive war, but there are enough objectors that it has a sizable effect on available personnel. First, it is worth stating that all combatants would have an equal opportunity to SCO. There is not too much room to complain if another

27 James Childress, Moral Responsibility, 215. 
takes advantage of an offer that one chooses to decline. However, if non-objectors sincerely believe the war is not aggressive, then without violating their own integrity they cannot take advantage of the allowance to SCO.

For such a case I propose a legal allowance for secondary SCO. Secondary SCO would allow non-participation for combatants who don't believe the war is aggressive, but who believe it is unfair for them to fight without the support of their objecting comrades. Secondary SCO would not require objectors to violate their integrity, since the reason for non-participation would not be that they think the war is aggressive, but rather that they think it unfair that they have to face an increased cost to themselves. If they still choose to fight at an increased cost to themselves, they would be free to do so, but they would have recourse other than accepting the increased cost. Setting the threshold for what the military will interpret and enforce as a substantial increase in the non-objectors' costs may be tricky, but that alone does not destroy the argument. I initially envision the substantial increase to occur at a small unit level, such as $25 \%$ of a 100 -person unit objecting. Of course in due time the unit could be properly staffed and the new members properly integrated. When this occurs, secondary SCO would no longer apply. Although less likely, I will not rule out the possibility of someone showing that at a larger level, widespread objections substantially increase their own risks or burdens. In addition, qualitative considerations could be considered such as for a unit that is reinforced quantitatively, but with less experienced or less well-trained members.

Is there potential for secondary SCO to be abused as an excuse to avoid fighting without having to demonstrate that the war is aggressive? This is not likely. For secondary SCO to apply, there would already have to be a significant number of objectors in order to cause a 
combatant's risks to substantially increase. Assuming the sorting process works correctly, a significant number of objectors should only occur for an aggressive war. Thus it would be difficult to abuse secondary SCO by using it as a way to avoid fighting a non-aggressive war.

With secondary SCO as an option, I can defuse this fairness critique. In one case nonobjectors receive a benefit, in the next case there is no change, and in the third case, nonobjectors have an opportunity for relief from having to face substantial increases in costs to themselves. In none of the scenarios do non-objectors face increased costs except by consent. I suspect that the number of persons who object via secondary selective conscientious objection would be low. Still it is important to include to ensure fairness. In addition to fixing this possible unfairness, an added advantage of secondary SCO is that it would further increase the difficulty of a state instigating an aggressive war (as now even more combatants might object) thus helping to fulfill a Type II-2 duty to protect by institutional design.

\section{Change Of Heart}

Another issue of fairness to fellow combatants is what to do if a combatant experiences a change of heart while in combat. Cheyney Ryan writes, "Most soldiers that I knew from the Vietnam War only decided that the war was unjust when they got there. Many came to this conclusion in the midst of combat, when the significance of what they were doing was brought home." ${ }^{28}$ I don't have the background in psychology to thoroughly investigate why this might be, but I would briefly suggest that actual participation and seeing the effects of combat may have made a combatant's sense of responsibility more apparent. Engaging in the action spurs reflection; until then perhaps the idea of combat and personal involvement is too abstract.

\footnotetext{
${ }^{28}$ Cheyney Ryan, “Democratic Duty and the Moral Dilemmas of Soldiers” Ethics, 122:1 (2011): 34.
} 
Certainly a legal prohibition of SCO and the proclamation of MEC don't encourage a combatant to strongly consider the moral implications of a war prior to fighting.

Another explanation is that combatants don't learn about the aggressiveness of a war they are fighting until actually in theater, but this does not seem to make much sense. It seems the issue is more likely a matter of encouragement to think rather than new empirical evidence that makes the difference. Due to these "midst of combat" objections, Ryan is concerned about "the impact on all soldiers of knowing that their fellow soldiers might defect at any moment." 29 There are at least two interpretations of "any moment" or "in the midst of combat;" a reactive interpretation and a reflective interpretation.

A reactive interpretation is that a combatant may experience a revelation as bullets are flying, and in that moment decide not to participate (i.e. not to fire his weapon or to fire it ineffectually). A reflective interpretation is that a combatant, while deployed but not actively engaged, will thoughtfully decide that in the future he will no longer participate. Without a duty or allowance of SCO both of these possibilities already exist, but I concede that SCO may increase the likelihood of a reflective objection. However, the biggest scare power of this concern is the reactive interpretation. For example, a combatant might be counting on a comrade to protect their flank, and suddenly this protection could cease. What factors influence a reactive objection and whether SCO would make it more likely is beyond my knowledge of human psychology.

As to a reflective objection, choosing to object is a monumental decision, and even if combatants think they experienced a revelation as bullets go by, it is the type of decision that

\footnotetext{
${ }^{29}$ Ibid., 34-35.
} 
they are likely to think about more before wholeheartedly executing. This seems true descriptively. Normatively, McMahan argues that combatants should take more time to further consider SCO under "conditions more conductive to rational deliberation." ${ }^{30}$ He does not clarify what exactly this means, but implies that this could occur while still deployed to a combat zone. It seems that, if combatants have the opportunity to read and write letters, they probably also have the opportunity for moral reflection. A required period of reflection would be good advice for any combatant who wants to get their decision right. Also, if the application for SCO requires even a minimum of paperwork (or the electronic equivalent), it would have to wait until after immediate fighting has ceased.

Should a reflective objection be a concern for a fellow combatant? While it may increase burdens and risks similar to how they are discussed in the secondary SCO section, the scare factor is not as high as for a reactive defection. Furthermore, provisions to allow combatzone SCO would probably be preferred by fellow combatants over forcing an unwilling person to continue to participate and, perhaps in desperation, feign participation, surrender, or worse.

A better situation is if a combatant makes their objection prior to deploying. Regarding the Vietnam War, McMahan writes, "If soldiers and potential conscripts had accepted that it was their responsibility to determine that the war was not unjust before allowing themselves to fight in it, more would have refused to go in the first place rather than having to discover the truth only after they had become complicit." ${ }^{31}$ Educating combatants of their moral requirement to research a war (or potential war) and to object to aggressive wars, along with a legal allowance to do so, will hopefully reduce the need to object once deployed, thereby

\footnotetext{
${ }^{30}$ McMahan, “Response," 141.

${ }^{31}$ lbid., 42.
} 
defanging this concern. Of course, even better than objecting prior to deployment is the case where the deterrent effect of SCO prevents a combatant from being ordered to participate in an aggressive war.

\section{The Sorting Process}

In defending SCO, I am counting on a sorting process to do a lot of work towards disallowing illegitimate claims. However, I have not given many details about what it should look like. First, what standard of judgment should the process use when considering combatants' claims? Second, how should the process be designed? In general, a sorting process needs to guard against two extremes. It needs to avoid setting the bar so high that very few objections are allowed and SCO is unable to serve as a barrier to aggressive wars. At the other extreme, it needs to prevent the abuse of SCO by those who object insincerely and the misuse of SCO by those who object mistakenly or for reasons other than the war is aggressive. Just as some legal systems err on the side of incorrectly acquitting the guilty versus incorrectly convicting the innocent, the sorting system should err on the side of granting a claim to the insincere, mistaken, or misaimed objector rather than denying a sincere and reasonably defendable claim.

The goal is for combatants to object to wars that are aggressive, but not to wars that are non-aggressive. However, McMahan shares, "There is no impartial and authoritative source of judgment about whether a war is just or unjust." ${ }^{\prime 32}$ Therefore, each combatant will have to decide the issue for himself or herself, meaning individual belief does matter. However, combatants should not to be able to object based on insincere or unjustifiable beliefs. A

\footnotetext{
${ }^{32}$ Jeff McMahan, Foreword, XIV.
} 
combatant's burden of proof should be to demonstrate a sincere and reasonably defendable belief that the war is aggressive. I concede that sincerity can be difficult to verify, and I will demonstrate how I intend to overcome this. Furthermore, I acknowledge that "reasonably defendable" is a vague term. As previously argued, vague language is not necessarily a weakness. Instead, vague language provides flexibility which can be a strength.

The belief needs to be sincere and reasonably defendable, but combatants do not need to conclusively prove that a war is aggressive. Similarly, McMahan suggests that combatants object to a war they can "plausibly argue [is] unjust." ${ }^{33}$ Carl Ficarrotta argues the requirement to approve a claim should be "reasonable, attainable standards of proof that the applicant genuinely wants a deferral on deeply held moral or religious grounds." ${ }^{34}$ James Childress believes that an "objector's burden of proof should not be heavy," nor that it need be established "beyond a reasonable doubt."

As I am envisioning the sorting system, a sincere and reasonably defendable claim needs to be grounded in the fact that the war is aggressive and therefore would violate a combatant's duty to not participate in aggression. The claim should explain why the war is aggressive and should reference the lack of a just cause. The claimant should explain the origin of their beliefs, which would likely include a philosophical or religious base. A simple claim, such as "I heard on the news that the war is aggressive," should be denied. A claimant needs to give justification. For example: "I began to research just war theory and aggression...," or "I reflected on training I received early in my career... and realized this war is aggressive because there is no just cause.

\footnotetext{
${ }^{33}$ McMahan, Killing, 99.

${ }^{34}$ Ficarrotta, "Implementation," 199. It is interesting to note that his work was the only one I encountered that is focused on the implementation of SCO.

${ }^{35}$ Childress, Moral Responsibility, 215.
} 
It appears the reason we are fighting is to gain territory, demonstrate power, etc." A combatant could also claim that although a just cause has been stated by the government, the available evidence does not support such a claim. There does not need to be a requirement to reference specific theorists or their works, although this could improve the strength of their claim.

The sorting process should reject a claim that is primarily political, such as the war is "imprudent because it is too expensive, or not in the (non-moral) national interest." 36 Following the top-down method, it should not include objections to wars that are unjust for failing other jus ad bellum criteria, but there is room for future expansion if utilizing a different grounding for the duty to object. In addition to rejecting a misaimed claim that fails to address aggression, the sorting process should also reject a mistaken claim. An example of a mistaken belief would be if in WWII a U.S. soldier claimed that U.S. participation in the war was aggressive. Of course the sorting process should also reject an insincere claim. Determining sincerity is a large focus of the design process to which I will now turn.

After establishing a standard the next question is how should the process be designed? Options range from a standardized form submitted to an approving official to a robust inperson investigative panel. An approval official, although less expensive, may not be able to judge the claim as well as a live panel composed of many members with varying skills. Of course, a panel will be much more expensive.

Should the claimant be required to withstand some sort of critical examination to demonstrate sincerity? If so, what would be required? I have no expertise in this area, but

\footnotetext{
${ }^{36}$ Ficarrotta, “Implementation,” 210.
} 
lawyers, psychologists, detectives, interrogators, and others in this field have vast experience with getting at the truth, and what conditions would be needed to do to so. ${ }^{37}$ Certainly in designing a sorting procedure we should consult these experts. At the extreme, examiners could provide zealous advocacy on behalf of the government, similar to the aggressiveness displayed at a criminal trial. A less expensive option that still retains the threat of rejecting insincere claims, is to "audit" (via critical examination) a certain percentage of claims, or those that are suspicious, but not require such extreme measures for every claim. ${ }^{38}$ Claims that look suspicious could be ones that appear to be plagiarized, but again I would defer to the expertise of others trained at discovering the truth for what clues to use. By requiring a critical examination we reduce the possibility that someone has simply cut and pasted the verbiage of someone else, and that they do not sincerely believe or even understand what is typed. This will certainly add to the expense of SCO, but it could prevent abuse. Less costly methods may be to conduct the examination by phone or video conference (assuming experts believe this could be effective), or to require just a few people on a panel.

An advantage of a panel is that it can be composed of members with various skills and knowledge. Who should these members be? A background in just war theory is important, but skill in questioning is also important. It is not likely that an academic expert in just war theory will have much experience with cross-examinations (although we should not discount the experience gained from working with students). On the other hand an experienced lawyer or

\footnotetext{
${ }^{37}$ Larry May, "Contingent Pacifism and Selective Refusal," Journal of Social Philosophy, 43:1 (2012): 15.

${ }^{38}$ Ficarrotta recommends a panel or board only be used the level of an appeal, citing cost and its cumbersome nature (“Implementation," 209).
} 
interrogator may have little knowledge of just war theory. A panel enables multiple people to fulfill separate roles, versus requiring one person to have expertise in divergent areas.

As an alternative to a panel, a more minimalist conception could have officials approve the claims by examining the individual or by reviewing an $\mathrm{SCO}$ application form. It seems that a form may be easy to submit insincerely by plagiarizing a website that it is bound to appear supporting combatants wanting to SCO. Not that such websites or support groups should not be allowed, but they should be used to inform a combatant's beliefs, not to allow them to fake a belief. This is where a requirement or option of a critical examination could be important. Although it increases costs, another possibility to increase reliability is to have two reviewers for every form and, if their opinions differ, to obtain a third and deciding opinion.

Another consideration is that after completing the form a claimant would notify their immediate commander, who would then inform the approvers whether they believe the claimant is sincere and give a brief statement as to why. In cases where the immediate commander thinks the claimant sincere, it is likely they are. Cases where the immediate commander does not think the objector is sincere can be ones that require extra scrutiny. The commander would in no way be approving or disapproving the application, just giving an opinion on sincerity. Also, the commander should have the prerogative to consult the claimant's supervisor and other key unit members. Strong protections should be put in place ensuring that any consultations are confidential to prevent gossip and retribution.

Experimentation is likely needed to determine what will be needed to design the system. For example, actors pretending to be objectors could present their claims. We could then determine if panels or approvers work better, and if so how much better to be worth the 
increased cost. We can determine what skills and experiences are needed. For example we may discover that minimal theoretical background is required and that what really matters is interrogation skills. Or we may discover that academics steeped in just war theory have the most success. As much as philosophers prefer thought experiments, in this case it seems actual experiments will be in order. Certainly designing the sorting process is a task that calls for extra-philosophical skills. ${ }^{39}$

It may be that experimentation shows that the only process that will work will be somewhat large panels that must meet in person. Will such costs defeat the reasonability of SCO? The worst case scenario may be a large panel is required to meet in person and needs an hour with each claimant. I will assume a ten-hour workday to make the math easier, but this may be longer hours than the board members can effectively work. Only ten claimants can be processed a day per panel, or fifty per week. If there were ten such panels located throughout the country then they could only process 500 claimants per week. Would that be enough to meet possible demand? I really don't know. Hopefully, a blatantly aggressive war would produce a much higher number of objectors. However, for a non-aggressive war this would likely be enough to reject illegitimate claims.

Serving on these panels would not be full-time job as for the most part the panels would be dormant. The panel members would need to otherwise be employed in jobs that allowed them to be absent when the state needs them. If obtaining a sufficient number of reviewers is difficult, I should note that a backlog of claims would contribute towards the end of preventing

\footnotetext{
${ }^{39}$ Shue remarks that institutional design "does indeed involve extra-philosophical information and skills in addition to philosophical ones, [...] but this only makes the philosophical work more challenging, not less essential" (Basic Rights, 169-170).
} 
an aggressive war. If claimants are not deployable while their claim is processed, then this serves the purpose of discouraging state aggression. A claimant who is waiting to be heard should not be required to participate in the aggressive war until after their objection is resolved, and then only if their claim is not upheld, and perhaps an appeal is denied as well. We should bear in mind that an advantage of an all-volunteer force is that military members are usually eager to serve. The process would not likely need to weed-out reluctant conscripts who may be hiding cowardice or completely lacking a desire to serve. As such, Carl Ficarrotta is not worried about a robust sorting process. He believes that due to social and psychological pressures encouraging participation, any combatant who applies for SCO is likely sincere. ${ }^{40}$ Examples of these pressures are "patriotism, group solidarity, self-justification mechanisms of various sorts, fear of being branded a coward, [a] strong desire to continue serving in other capacities (and to continue one's career). ${ }^{\prime 41}$ One interpretation is that the act of applying is so difficult that only the sincere would attempt it. I think for the most part this is true, but I will discuss one exception later.

Cowardice is one specific concern Ficarrotta mentions. He thinks that in an all-volunteer force, most cowards would not have self-selected into the military. ${ }^{42}$ We could add that cowards are even less likely to have self-selected into the more dangerous career fields. Certainly there are strong pressures to not be thought a coward. There is an example of Colonel Eli Geva of the Israeli Defense Force who refused to lead an attack in Beirut that he thought was unjust, but who volunteered to serve as an enlisted member on the same mission

\footnotetext{
${ }^{40}$ Ficarrotta, “Implementation," 199-200.

41 lbid., 99.

42 Ibid., 200-201.
} 
as a way of demonstrating that it was not cowardice motivating his decision. It should be noted that his objection proved to be instrumental in cancelling the planned offensive. ${ }^{43}$ The provision for objectors to serve in a different war or to be assigned to other arduous or austere assignments is another method for the member to demonstrate sincerity and deflect charges of cowardice or weakness, as well as for the state to ensure a return on their investment.

From Ficarrotta's perspective, a state should have the presumption that an objector is sincere. From this starting point, a more streamlined appeal process could be enabled and panels and critical examinations reserved for either randomly audited cases or cases where there is evidence that a member is trying to abuse the system. I would like to consider one exception to Ficarrotta's theory that most objectors are sincere. What about someone who from the moment of enlistment has been insincere? It could be someone who joined with no intention to ever serve, even in a just war, and who planned to use SCO (as well as any other conceivable options) as a way to avoid fighting. Due do their likely failure to assimilate into their unit or the military at large, they would be less influenced by outside pressures. While this is a possibility, I don't think it is very likely. Furthermore, someone such as this would be a candidate for further scrutiny.

We should bear in mind that volunteering for the military with the intention to never fight is not that easy. The member has to complete a great deal of training and do a lot of work besides actual combat. Someone thoroughly opposed to the military would likely find their time very difficult and without being too dramatic, dare I say, "torturous." They would spend years surrounded by those eager to train and fight and endure a highly regimented lifestyle

\footnotetext{
${ }^{43}$ William Ian Miller, The Mystery of Courage (Cambridge: Harvard University Press, 2000), 257-258.
} 
without the motivation of believing they are doing it for a cause higher than material benefits. It is possible someone utterly insincere could endure, but there are probably better ways of getting an equivalent amount of pay and benefits for less work, in better working conditions, and with colleagues one does not differ from in such fundamental ways. It seems that if someone's goal is to fool the system by gaining a paycheck and benefits without having to do the requisite work, the insincere member is the one who is fooled in the deal. Also, a provision to deploy an objector elsewhere could reduce the likelihood an insincere member would actually avoid fighting or austere conditions.

I have mentioned alternative assignments for objectors as well as protections to prevent retributions. I will expand on both issues. By requiring continued service, the government can recoup the return on their investment, while also not providing what some would say is the perverse incentive of training, pay, and benefits with an easy exit from the military. More positively, many members would view the ability to continue to serve as an opportunity, not a disincentive to insincere claims. Many objectors would want to continue service in what they consider to be an important job, as well as to remain employed in order to pay the bills. Lack of employment should not be a concern that keeps combatants from choosing the morally right action. Furthermore, leaving the service would prevent military members from having the opportunity to serve their state by deterring aggressive war and, if needed, defend against aggression. This may very well be the reason they joined the military in the first place.

In addition to an objection not immediately ending one's career, an objection should also not have negative long-term career effects. I agree with Ficarrotta that an objection 
should be masked from future promotion and assignment boards. ${ }^{44}$ An odd assignment history due to being reassigned may be difficult to hide, so I would go one step further and instruct boards that suspicions of a member having objected are not to be used as a basis for consideration. Also, to ease completion of the application, the form should be kept as simple as possible, and the military should provide resources to assist such as chaplains, lawyers, counselors, etc. ${ }^{45}$

Imagine if we were trying to design a legal system from scratch. It would be a daunting task and initially there may not be a clear way to proceed. However, we would not consider the difficulty of such a task to be a reason to not make or enforce laws. In the same way, although settling the details of how to sort SCO claims will bring up difficulties, this does not need to be a reason to scrap the entire enterprise. Although it may be costly, even in a near worst case scenario it can be assumed that some system would be able to sort the claims. It may be as elaborate as a criminal trial, or perhaps simply a panel of five examiners. It might be as simple as individual investigators conducting phone or video interviews. Or perhaps Ficarrotta is right, and the act of objecting is so difficult that it pretty much ensures sincerity.

There is also a lot to be said for actual experimenting among various states. First, due to variances in governments and cultures, the same system may not be most ideal everywhere. As previously shown, the idea of varying institutional design requirements is supported by Shue. ${ }^{46}$ Furthermore, states trying a variety of approaches may determine which approaches are most effective and thus should be considered for adoption by other states. I am open to whatever

\footnotetext{
${ }^{44}$ Ficarrotta, "Implementation," 208.

${ }^{45}$ Ibid., 199.

${ }^{46}$ Shue, Basic Rights, 17.
} 
process is needed to enact SCO and believe that even the most costly options discussed so far would still be reasonable on balance with the benefits of SCO. It would be best to consult outside expertise and obtain empirical data (to be gained from role-playing exercises) to achieve the most reasonable design.

Without further empirical data, I would opt for a presumption that a combatant is sincere, and for the most part applications would be easily approved. The application would be a simple form which would include an opportunity for members to volunteer for specific duties or to address how they are willing to continue to serve. I would require commander notification and a commander's recommendation of sincerity. The application form, with the commander's recommendation, would be considered by an approving official well versed in just war theory who would either approve the claim or send the claimant to a live panel for further clarification. The panel would be composed of three to five members who are either knowledgeable in just war theory or trained in critical examination. Those approved at either level would be reassigned or have their duties adjusted to account for their objection. Those not approved would have the opportunity to appeal, but otherwise would continue to serve in their present duties. The process for secondary SCO would be the similar. This flexible response seems to be the more reasonable option than spending a large amount of resources to frequently uphold the fact that an objector is sincere. If insincere objectors become a common problem, then the system can always be bolstered later. At that point, if the need exists, there will hopefully be some data to help create a more tailored response. 


\section{Concluding Thoughts}

Although I have not discovered Shue applying his tripartite framework to just war theory, he has written on just war theory. Are his opinions consistent with what I have developed? Shue expresses a desire that we take action to prevent aggressive wars: "I believe that we ought to do everything morally acceptable in our power to prevent virtually all wars, especially wars of first resort like the catastrophe inflicted upon Iraq by Bush/Cheney." ${ }^{1}$ He also believes that we should discourage combatants from fighting in such wars: "Some wars will in fact occur whether the resort to war is ever justified or not. When they are not justified we should obviously say so and we should urge young people not to fight in them." ${ }^{2}$

Furthermore, Shue believes combatants should investigate the justice of their state's cause: "It is supremely important to discover whether what the state is telling you to do ought to be done. Bush/Cheney (and Blair) lied about Iraq; governments often lie to young people whom they would like to have kill and die for them." ${ }^{3}$ Finally, he believes that individuals should choose to not participate in an unjust war:

Unjust wars ought not to be pursued, and no one ought to participate in them on the unjust side. This is the principle governing the resort to war (jus ad bellum), and, [...] it ought to be the principle governing individual choice about whether to participate in war. If it is unjust, do not do it. Only initiate a war, if you are a leader, or fight in a war, if you are a soldier, if it is just-really just, objectively just. ${ }^{4}$

In sum, it appears that Shue would support the conclusions I have drawn while relying on his tripartite framework.

\footnotetext{
${ }^{1}$ Shue, Henry, "Do We Need a 'Morality of War'?" in Just and Unjust Warriors, edited by David Rodin and Henry Shue (Oxford: Oxford University Press, 2008), 105.

${ }^{2}$ Ibid.

3 Ibid., 108.

${ }^{4}$ Ibid., 107.
} 
I have argued that just war theory should require a moral duty of selective conscientious objection. Furthermore, I have argued that states should provide a legal allowance for selective conscientious objection and that international law should require states to provide this allowance. The reason for these changes is due to the potential to deter aggressive wars. In sum, the changes discussed in this dissertation will morally empower combatants and thereby reduce the likelihood of aggressive wars. 


\section{Bibliography}

Aristotle. Nicomachean Ethics. In Classics of Moral and Political Theory, $4^{\text {th }}$ ed., edited by Michael Morgan 255-360. Indianapolis: Hackett Publishing, 2005.

Art of Theory. "Michael Walzer: The Art Of Theory Interview" accessed May 5, 2015, http://www.artoftheory.com/michael-walzer-the-art-of-theory-interview/.

Ashford, Elizabeth. "The Alleged Dichotomy Between Positive and Negative Rights and Duties." In Global Basic Rights, edited by Charles Beitz and Robert Goodin, 92-112. Oxford: Oxford University Press, 2009.

Beitz, Charles and Robert Goodin. Introduction to Global Basic Rights, edited by Charles Beitz and Robert Goodin, 1-24. Oxford: Oxford University Press, 2009.

Benbaji, Yitzhak. "The Moral Power of Soldiers to Undertake the Duty of Obedience." Ethics, 122:1 (2011), 43-73.

Coady, C. A. J. "Objecting Morally." The Journal of Ethics, 1:4 (1997): 375-397.

Coates, Anthony. "Is the Independent Application of jus in bello the Way to Limit War?" In Just and Unjust Warriors, edited by David Rodin and Henry Shue, 176-192. Oxford: Oxford University Press, 2008.

Childress, James. "Just-War Theories: The Bases, Interrelation, Priorities, and Functions of Their Criteria." Theological Studies, 39:3 (1978): 427-445.

Childress, James. Moral Responsibility in Conflict. Baton Rouge: Louisiana State University Press, 1982.

Christopher, Paul. The Ethics of War \& Peace: An Introduction to Legal and Moral Issues, $2^{\text {nd }}$ ed. Upper Saddle River: Prentice Hall, 1999.

Fiala, Andrew. Public War, Private Conscience. New York: Continuum International Publishing Group, 2010.

Ficarotta, J. Carl. "Selective Conscientious Objection: Some Guidelines for Implementation." In When Soldiers Say No, edited by Andrea Ellner, Paul Robinson, and David Whetham, 197-211. Burlington: Ashgate, 2014.

Fisher, David. Morality and War. Oxford: Oxford University Press, 2011. 
Fisher, David. "Who Guards the Guards? The Importance of Civilian Control of the Military." In When Soldiers Say No, edited by Andrea Ellner, Paul Robinson, and David Whetham, 63-76. Burlington: Ashgate, 2014.

Felice, William. How Do I Save My Honor? Lanham: Rowman and Littlefield Publishers, 2009.

Foster, Gregory. "Selective Conscientious Objection." Society, 46:5 (2009): 390-393.

French, Shannon. "Sergeant Davis's Stern Charge: The Obligation of Officers to Preserve the Humanity of Their Troops." Journal of Military Ethics, 8:2 (2009): 116-126.

Holmes, Stephen \& Cass Sunstein. The Cost of Rights. New York: W. W. Norton, 1999.

Jensen, Mark. "Hard Choices in the Military." Journal of Military Ethics, 2:4 (2013): 341-356.

Johnson, James Turner. Just War Tradition and the Restraint of War. Princeton: Princeton University Press, 1981.

Kant, Immanuel. Grounding for the Metaphysics of Morals. In Classics of Moral and Political Theory, $4^{\text {th }}$ ed., edited by Michael Morgan, Translated by James W. Ellington, 893-933. Indianapolis: Hackett Publishing, 2005.

Kaufman, Whitley. "Book Review of McMahan, Jeff: Killing in War." Ethics 120:2 (2010): 399404

Kiper, Jordan. "Henry Shue on Basic Rights: A Defense." Human Rights Review, 12:4 (2011): 505-514.

Locke, John. Second Treatise of Government. In Classics of Moral and Political Theory, $4{ }^{\text {th }}$ ed., edited by Michael Morgan 684-749. Indianapolis: Hackett Publishing, 2005.

Lucas, George. "Advice and Dissent: 'The Uniform Perspective'." Journal of Military Ethics, 8:2 (2009): 141-161.

May, Larry. "Contingent Pacifism and Selective Refusal." Journal of Social Philosophy, 43:1 (2012): 1-18.

Marlantes, Karl. What it is Like to Go to War. New York, Atlantic Monthly Press, 2011.

McGinn, Colin. "Reasons and Unreasons." Review of What We Owe to Each Other by T. M. Scanlon. New Republic, May $24^{\text {th }}, 1999,34-38$. 
McMahan, Jeff. "Collectivist Defenses of the Moral Equality of Combatants." Journal of Military Ethics, 6:1 (2007): 50-59.

McMahan, Jeff. "Duty, Obedience, Desert, and Proportionality in War: A Response." Ethics, 122:1 (2011), 135-167.

McMahan, Jeff. Foreword to When Soldiers Say No, edited by Andrea Ellner, Paul Robinson, and David Whetham, XI-XVI. Burlington: Ashgate, 2014.

McMahan, Jeff. Killing In War. New York: Oxford University Press, 2009.

McMahan, Jeff. "The Morality of War and the Law of War." In Just and Unjust Warriors, edited by David Rodin and Henry Shue, 19-43. Oxford: Oxford University Press, 2008.

McMahan, Jeff. "The Sources and Status of Just War Principles." Journal of Military Ethics, 6:2 (2007): 91-106.

McMahan, Jeff. "War as Self-Defense." Ethics and International Affairs, 18:1 (2004): 75-80.

Miller, Joseph. "Jus ad bellum and an Officer's Moral Obligations." Social Theory and Practice, 30:4 (2004): 457-484.

Miller, William Ian. The Mystery of Courage. Cambridge: Harvard University Press, 2000.

MacFarquhar, Neil. "U.N. Treaty Is First Aimed at Regulating Global Arms Sales." The New York Times. April 2, 2013. Accessed 26 April 2013.

http://www.nytimes.com/2013/04/03/world/arms-trade-treaty-approved-atun.html?pagewanted $=a l l \& \quad r=0$

O’Neill, Onora. Bounds of Justice. Cambridge: Cambridge University Press, 2000.

O’Neill, Onora. Towards Justice and Virtue. Cambridge: Cambridge University Press, 1996.

Orend, Brian. The Morality of War. Toronto: Broadview Press, 2006.

Orend, Brian. Michael Walzer on War and Justice. Cardiff: University of Wales Press, 2000.

Orend, Brian. War and International Justice: A Kantian Perspective. Waterloo: Wilfrid Laurier University Press, 2000.

Payne, Michael. "Henry Shue on Basic Rights." Essays in Philosophy, 9:2 (2008): Article 5. 
Plato. Apology. In Five Dialogues. Translated G. M. A. Grube. Indianapolis: Hackett Publishing, 1981.

Pogge, Thomas. World Poverty and Human Rights, $2^{\text {nd }}$ edition. Cambridge: Polity Press, 2008.

Rawls, John. A Theory of Justice. Cambridge: Harvard University Press, 1971.

Rawls, John. The Law of Peoples. Cambridge: Harvard University Press, 2002.

Reichburg, Gregory. "Just War and Regular War: Competing Paradigms." In Just and Unjust Warriors, edited by David Rodin and Henry Shue, 193-213. Oxford: Oxford University Press, 2008.

Roberts, Adam. "The Principle of Equal Application of the Laws of War." In Just and Unjust Warriors, edited by David Rodin and Henry Shue, 226-254. Oxford: Oxford University Press, 2008.

Robinson, Paul. "Integrity and Selective Conscientious Objection." Journal of Military Ethics, 8:1 (2009): 34-47.

Rodin, David. "The Moral Inequality of Soldiers: Why jus in bello Asymmetry is Half Right." In Just and Unjust Warriors, edited by David Rodin and Henry Shue, 44-68. Oxford: Oxford University Press, 2008.

Rodin, David and Henry Shue. Introduction to Just and Unjust Warriors, edited by David Rodin and Henry Shue, 1-18. Oxford: Oxford University Press, 2008.

Rodin, David. War and Self Defense. Oxford: Oxford University Press, 2002.

Roush, Paul. "Constitutional Ethics." In Ethics and the Military Profession: The Moral Foundations of Leadership. Boston: Pearson Learning Solutions, 2010.

Ryan, Cheyney. "Democratic Duty and the Moral Dilemmas of Soldiers." Ethics, 122:1 (2011), 10-42.

Ryan, Cheyney. "Moral Equality, Victimhood, and the Sovereignty Symmetry Problem." In Just and Unjust Warriors, edited by David Rodin and Henry Shue, 131-152. Oxford: Oxford University Press, 2008.

Scanlon, T. M. What We Owe to Each Other. Cambridge: The Belknap Press of Harvard University Press, 1998. 
Schoonhoven, Richard. "Invincible Ignorance, Moral Equality, and Professional Obligation." In Empowering Our Military Conscience Transforming Just War Theory and Military Moral

Education, edited by Roger Wertheimer, 107-129. Famham: Ashgate Publishing Group, 2010.

Shue, Henry. Basic Rights: Subsistence, Affluence, and U. S. Foreign Policy, 1st ed. Princeton: Princeton University Press, 1980.

Shue, Henry. Afterword to Basic Rights: Subsistence, Affluence, and U. S. Foreign Policy, 2nd ed. Princeton: Princeton University Press, 1996.

Shue, Henry. "Do We Need a 'Morality of War'?" In Just and Unjust Warriors, edited by David Rodin and Henry Shue, 87-111. Oxford: Oxford University Press, 2008.

Shue, Henry. "Mediating Duties." Ethics, 98:4 (1998): 687-704.

Sola, Andrew. "The Enlightened Grunt? Invincible Ignorance in the Just War Tradition." Journal of Military Ethics, 8:1 (2009): 48-65.

Suárez, Francisco. The Three Theological Virtues: On Charity, in Selections From Three Works of Francisco Suárez, translated by Gwladys L Williams et al. Oxford: Clarendon Press, 1944.

Vitoria, Francisco de. On the Law of War. In The Ethics of War: Classic and Contemporary Readings, edited by Gregory Reichburg, Henrik Syse, and Endre Begby, 308-332. Malden: Blackwell Publishing, 2006.

Wakin, Malham. Integrity First. Lanham: Lexington Books, 2000.

Waldron, Jeremy. Liberal Rights. Cambridge: Cambridge University Press, 1993.

Waldron, Jeremy. "Security as a Basic Right (After 9/11)." In Global Basic Rights, edited by Charles Beitz and Robert Goodin, 207-226. Oxford: Oxford University Press, 2009.

Walzer, Michael. Arguing About War. New Haven: Yale University Press, 2005.

Walzer, Michael. "Coda: Can the Good Guys Win?" European Journal of International Law, 24:1 (2013): 433-444.

Walzer, Michael. Just and Unjust Wars, $2^{\text {nd }}$ ed. United States: Basic Books, 1992.

Walzer, Michael. "The Moral Standing of States," Philosophy and Public Affairs, 9:3 (1980): 209229. 
Wertheimer, Roger. Introduction to Empowering Our Military Conscience Transforming Just War Theory and Military Moral Education, edited by Roger Wertheimer, 1-11. Famham: Ashgate Publishing Group, 2010.

Wertheimer, Roger. "The Morality of Military Ethics Education." In Empowering Our Military Conscience Transforming Just War Theory and Military Moral Education, edited by Roger Wertheimer, 159-196. Famham: Ashgate Publishing Group, 2010.

Wertheimer, Roger. "Reconnoitering Combatant Moral Equality." Journal of Military Ethics, 6:1 (2007): 60-74.

Wolfendale, Jessica. "Professional Integrity and Disobedience in the Military." Journal of Military Ethics, 8:2 (2009): 127-140.

Wolfendale, Jessica. Torture and the Military Profession. New York: Palgrave, 2007.

Zupan, Dan. "The Logic of Community, Ignorance, and the Presumption of Moral Equality: A Soldier's Story." Journal of Military Ethics, 6:1 (2007): 41-49. 